\title{
Good Golly, Why Moly? \\ The Stable Isotope Geochemistry of Molybdenum
}

\author{
Brian Kendall* \\ Department of Earth and Environmental Sciences \\ University of Waterloo \\ Waterloo, ON, Canada N2L $3 G 1$ \\ Tais W. Dahl* \\ Natural History Museum of Denmark \\ University of Copenhagen \\ Copenhagen, Denmark \\ Ariel D. Anbar \\ School of Earth and Space Exploration \\ School of Molecular Sciences \\ Arizona State University \\ Tempe, AZ 85287 \\ * Both authors contributed equally to this work.
}

Accepted Manuscript for Reviews in Mineralogy and Geochemistry

2017

https://doi.org/10.2138/rmg.2017.82.16 


\section{INTRODUCTION}

"The Answer to the Great Question... Of Life, the Universe and Everything... Is... Forty-two," said Deep Thought, with infinite majesty and calm... "I checked it very thoroughly," said the computer, "and that quite definitely is the answer."

- Douglas Adams, The Hitchhiker's Guide to the Galaxy

Molybdenum (Mo) - the element with atomic number 42 - possesses unique properties that make it the answer to many questions in the geosciences, life sciences, and industry.

In the geosciences, the redox sensitivity of Mo makes it particularly useful for answering questions about environmental redox conditions. In particular, it was first suggested as an ocean paleoredox proxy over 30 years ago (Holland, 1984; Emerson and Huested, 1991) - an application that finally came to fruition in the late 1990s and 2000s when understanding of Mo geochemical behavior in modern environments improved significantly (e.g., Crusius et al., 1996; Helz et al., 1996, 2011; Morford and Emerson, 1999; Erickson and Helz, 2000; Barling et al., 2001; Siebert et al., 2003, 2005; Arnold et al., 2004; Vorlicek et al., 2004; Morford et al., 2005; Algeo and Lyons, 2006; McManus et al., 2006; Poulson et al., 2006; Anbar et al., 2007; Wille et al., 2007; Pearce et al., 2008; Archer and Vance, 2008; Neubert et al., 2008; Scott et al., 2008; Gordon et al., 2009; Poulson Brucker et al., 2009).

In the life sciences, nature settled on Mo as the answer to the challenge of biological $\mathrm{N}_{2}$ fixation at least $\sim 2$ billion years ago (Boyd et al., 2011), with the evolution of the Mo-dependent nitrogenase enzyme. Molybdenum is also at the heart of nitrate reductase enzymes, which are essential for assimilatory and dissimilatory nitrate reduction (Glass et al., 2009). Therefore, Mo is central to the nitrogen biogeochemical cycle. This biological role combines with its geochemical behavior in ways that might drive aspects of the coevolution of life and environment (Anbar and Knoll, 2002).

Industrially, Mo is variously used as a catalyst, pigment, steel additive, and lubricant. Most of this use is in different types of steel, to improve physical properties like hardness and temperature strength, as well as chemical properties, notably corrosion resistance. Over 230,000 metric tons are used each year, mostly in China (IMOA, 2016). Porphyry molybdenum and copper-molybdenum deposits are the most important sources of molybdenite, the ore mineral of Mo.

Isotope geochemists were drawn to Mo because of its biogeochemical importance and economic value, and its seven stable isotopes, all relatively abundant $(10-25 \%)$ and covering a relatively wide mass range of $\sim 8 \%$ (Fig. 1). Beginning in the late 1990s, equipped with new multiple collector inductively coupled plasma mass spectrometers, they began to wonder if Mo isotope compositions varied significantly, and if Mo isotope fractionation could provide new answers to yet more questions. 
The subsequent $\sim 15$ years of research yielded an emphatic answer of "yes", centered in particular on paleoceanographic applications, but also extending to the solid Earth geosciences and other areas.

42

This review provides an overview of this maturing isotope system, with an emphasis on paleoredox applications that dominate the literature. It is intended as an update of the reviews written when the Mo isotope system was still emerging (Anbar, 2004; Anbar and Rouxel, 2007). Section 2 covers analytical methodology. Sections 3 and 4 provide the necessary context for Mo isotope studies by reviewing Mo biogeochemistry and Mo isotope fractionation factors. Section 5 explores Mo isotope variations in meteorites and Earth reservoirs, with an emphasis on the large database for marine sediments. In the context of modern observations of the ocean Mo cycle, the use of Mo isotopes as a local and global ocean paleoredox proxy is synthesized in section 6. In section 7, we explore the rapidly growing application of Mo isotopes to ore deposits, oil, and anthropogenic tracing, areas that are expected to see strong growth in the near future.

\section{ANALYTICAL CONSIDERATIONS}

\section{Data Reporting}

Molybdenum stable isotope fractionation is conventionally reported in $\delta^{98}$ Mo notation as parts per thousand deviation of the ${ }^{98} \mathrm{Mo} /{ }^{95} \mathrm{Mo}$ ratio relative to a universal reference material. Older data were reported relative to in-house reference materials thought to be identical in composition. However, the analytical precision has improved since then and a common reference material is necessary because various in-house reference materials now differ by up to $0.37 \%$ (Goldberg et al., 2013). The Mo standard solution, NIST-SRM-3134, has been defined as an international reference material, and is assigned a distinct $\delta^{98}$ Mo value of $0.25 \%$ to account for its offset from the most common in-house standards used previously (Nägler et al., 2014). On this scale, the Mo isotope composition of samples can be calculated as follows:

$$
\left.\delta^{98} \mathrm{Mo}=\left[\left({ }^{98} \mathrm{Mo} /{ }^{95} \mathrm{Mo}\right)_{\text {sample }} /\left({ }^{98} \mathrm{Mo} /{ }^{95} \mathrm{Mo}\right)_{\text {NIST-SRM-3134 }}\right)-1\right] \times 1000+0.25[\% 0]
$$

If the $\delta^{98}$ Mo of the in-house reference material relative to the NIST-SRM-3134 standard is known, then it is possible to re-normalize the Mo isotope composition of a sample from the inhouse reference scale to the NIST-SRM-3134 scale. If the isotopic offset between the in-house and NIST-SRM-3134 standards is not known, it is still possible to convert between the two scales by measuring a well-known secondary standard such as seawater (e.g., IAPSO) or the USGS rock reference material SDO- 1 , which has $\delta^{98} \mathrm{Mo}=1.05 \pm 0.14 \%$ o $(2 \sigma=2$ standard deviations) on the NIST-SRM-3134 scale (Goldberg et al. 2013; Nägler et al., 2014). 
Hence, the NIST-SRM-3134 scale facilitates the comparison of future work with almost all older data within a reasonable level of precision. On this scale, open ocean water samples have $\delta^{98} \mathrm{Mo}$ $=2.34 \pm 0.10 \%$ irrespective of ocean basin or water depth (Barling et al., 2001; Siebert et al., 2003; Greber et al., 2012; Nakagawa et al., 2012; Goldberg et al., 2013), except in the deep waters of restricted anoxic basins (Nägler et al., 2011; Noordmann et al., 2015) or in highly productive surface ocean waters (Kowalski et al., 2013). This is indistinguishable from the canonical value of $2.3 \%$ suggested from earlier work. In this review, all values of $\delta^{98} \mathrm{Mo}$ are reported relative to NIST-SRM-3134 $=0.25 \%$.

\section{Chemical Separation}

The Mo isotope composition of molybdenite $\left(\mathrm{MoS}_{2}\right)$ can be measured precisely and accurately using mass spectrometry after sample dissolution and dilution because Mo and S are the only major elements in the molybdenite crystal structure (Barling et al., 2001). However, most other natural materials have low Mo abundances $(<100 \mathrm{ppm})$ and much higher concentrations of other elements, and thus require pre-concentration and purification of Mo before the isotope composition can be measured. Doing so minimizes the problem of matrix effects, which arise when the presence of other elements causes the formation of ionic compounds with masses that are similar to those of the Mo isotopes. Such "interferences" on Mo isotope masses can preclude accurate measurement of Mo isotope compositions unless adequately corrected for or minimized.

Removal of $\mathrm{Fe}$ and $\mathrm{Mn}$ is particularly critical to minimize the formation of argides, which produce polyatomic interferences at masses 94-97. For example, the Fe/Mo ratio in the analyte should be less than 1 to avoid measurable interferences when using multiple collector inductively coupled plasma mass spectrometry (MC-ICP-MS) (Malinovsky et al., 2005). Zirconium has isobaric interferences with Mo on masses 92, 94 and 96, but Mo is efficiently separated from $\mathrm{Zr}$ during purification. Both Ru and doubly-charged W interfere on masses 96-100 and 92, respectively, but this has mainly been a concern for synthetic materials and meteorite samples (Burkhardt et al., 2011; Migeon et al., 2015). Other elements including Si may affect the measured isotope ratios, and $\mathrm{Si} / \mathrm{Mo}$ ratios less than 50 are recommended to avoid such matrix effects (Malinovsky et al., 2005).

100 For studies exploring Mo isotope variations in meteorites, where nucleosynthetic anomalies may affect the Mo isotope compositions, the measurement of purified Mo without interferences from $\mathrm{Zr}, \mathrm{Ru}$, and $\mathrm{W}$ is particularly important. Furthermore, comparison of mass-dependent Mo isotope meteorite classes except for achondritic, lunar, and Martian meteorites (Burkhardt et al., 2014). 
Traditionally, Mo is separated from the matrix elements using ion exchange chromatography. Most schemes deploy both an anion exchange column (e.g., Bio-Rad ${ }^{\mathrm{TM}}$ AG1-X8, Dowex AG1, Eichrom AG1X8) to separate Mo from $\mathrm{Zr}$ and most other matrix elements, and a cation exchange column (e.g., Bio-Rad ${ }^{\mathrm{TM}}$ AG50W-X8 or TRU-spec) to mainly separate Mo from Fe (Anbar et al., 2001; Barling et al., 2001; Siebert et al., 2001; Pietruszka et al., 2006; Migeon et al., 2015). However, purification using a chelating resin (Malinovsky et al., 2005), anion-only resin (Siebert et al., 2001; Pearce et al., 2009; Nagai and Yokoyama, 2016), or two distinct cation resins (Archer and Vance, 2008; Burkhardt et al., 2011) has also been successfully done.

A key observation is that Mo isotopes are fractionated during elution in anion exchange systems (e.g., Bio-Rad ${ }^{\mathrm{TM}}$ AG1-X8, Dowex AG1) (Anbar et al., 2001; Siebert et al., 2001). The magnitude of fractionation depends on the column yield, but is large enough $(\sim 1 \% / \mathrm{amu})$ to completely swamp natural variability (Anbar et al., 2001; Siebert et al., 2001). Therefore, it is necessary to either ensure quantitative yields during purification or to make a correction for isotope fractionation induced by this process. Mixing and equilibrating sample Mo with a double spike of known composition before purification allows for such a correction (discussed further below).

Mass Spectrometry

A fundamental challenge to stable isotope studies (not including mass-independent Mo isotope variations produced by nucleosynthesis; Dauphas et al., 2002a, 2002b, 2004; Yin et al., 2002; Fujii et al., 2006; Burkhardt et al., 2011, 2012) is that mass spectrometry induces massdependent isotope fractionation. Therefore, precise determination of the Mo stable isotope composition depends on a precise correction for such fractionation processes.

The magnitude of isotope fractionation differs markedly between MC-ICP-MS and thermal ionization mass spectrometry (TIMS). For MC-ICP-MS, the instrumental mass bias is large $(+17 \% / \mathrm{amu})$, but very stable, whereas TIMS produces variable mass bias of smaller magnitude, at $-6.4 \%$ /amu and $-0.5 \%$ /amu for positively and negatively charged ions, respectively (Wieser et al., 2007; Nagai and Yokoyama, 2016). In both cases, the instrumental isotope fractionation exceeds the variability in nature $(\sim 1 \% / \mathrm{amu})$, and thus a correction for instrumental mass bias is necessary. Wieser et al. (2007) compared the various mass spectrometric techniques and 133 concluded that MC-ICP-MS is the optimal method for accurately measuring the isotope 134 composition of Mo in natural materials. 
The earliest Mo isotope measurements were performed using TIMS in positive ion mode (PTIMS) with a $\mathrm{Mo}^{+}$beam, resulting in an analytical precision of 6\%/amu for each Mo isotope ratio, ${ }^{\mathrm{x}} \mathrm{Mo} /{ }^{100} \mathrm{Mo}$ (Murthy, 1962, 1963; Wetherill, 1964). The large uncertainty was due to the low ionization potential of Mo. Recently, it has been demonstrated that the latest generation TIMS instruments operating in negative ion mode (N-TIMS), measuring $\mathrm{MoO}_{3}^{-}$, can yield precisions of $<0.01 \% / \mathrm{amu}$ for ${ }^{\mathrm{x}} \mathrm{Mo} /{ }^{100} \mathrm{Mo}$ (Nagai and Yokoyama, 2016). To achieve highly precise Mo isotope ratios using N-TIMS, it is important to measure and correct for the oxygen isotope composition of the $\mathrm{MoO}_{3}^{-}$ions.

Three strategies have been applied to correct for instrumental mass bias during mass spectrometric analysis, including 1) standard-sample bracketing, 2) elemental spiking, and 3) double spiking. All methods are applicable to MC-ICP-MS, whereas double spiking is needed for TIMS analysis.

All three methods are summarized below.

Standard-sample bracketing. The simplest correction for instrumental mass bias is comparison of the sample to a standard run under the same instrumental conditions. Usually, analyses of samples are bracketed by standards to cope with systematic instrumental drift. This correction assumes that instrumental mass bias: a) has a constant drift during analysis, and b) does not vary systematically between samples and standards. In TIMS, instrumental mass bias changes continuously during analysis as a result of isotope enrichment during thermal evaporation and ionization (Murthy, 1962, 1963). Therefore, the standard-sample bracketing method is more applicable to MC-ICP-MS, where the instrumental mass bias is not a time-dependent phenomenon (Maréchal et al., 1999). This approach has been successful for some non-traditional isotope systems, including Fe (Beard et al., 2003), and may be suitable for isotopic analysis of molybdenite (Pietruszka et al., 2006). However, an efficient purification protocol is required for a trace metal such as Mo because variation in instrumental mass bias arising from matrix differences between sample and standard solutions cannot be corrected for. If efficient purification cannot be achieved, then other mass bias correction methods must be applied.

Element spike. In MC-ICP-MS, it is possible to dope the purified sample solution with another element immediately before analysis and simultaneously monitor changes in instrumental mass bias and Mo isotope fractionation in the sample. In principle, this correction is applicable without standard-sample bracketing, but typically it is used in combination with bracketing standards doped in an identical fashion as the samples. Some of the first modern observations of Mo isotope fractionation in geological materials employed $\mathrm{Zr}$ and $\mathrm{Ru}$ element spikes to yield $\delta^{98} \mathrm{Mo}$ values with a precision of $\sim 0.3 \%$ ( $2 \sigma)$ (Anbar et al., 2001). Later refinements improved precision to $\sim 0.15 \% 0(2 \sigma)$ (e.g., Duan et al., 2010). However, this approach rests on the assumption that the instrumental mass bias of $\mathrm{Zr}$ or $\mathrm{Ru}$ isotopes varies systematically with the instrumental mass bias of Mo isotopes. 
Isotopic double spike. For both MC-ICP-MS and TIMS, a correction for mass-dependent isotope fractionation that occurs during non-quantitative chromatographic purification and mass spectrometric analysis can be made using an isotopic double spike. The spike consists of two Mo isotopes with a known isotopic ratio. The fundamental advantage of this approach is that the spike isotopes follow exactly the same fractionation law as the isotopes of interest. This method can correct for isotope fractionation incurred during both chemical separation and mass spectrometry (Wetherill, 1964; Siebert et al., 2001). Therefore, a more pure chemical separation can be prioritized instead of an optimum yield.

Due to its large number of stable isotopes (Fig. 1), Mo is particularly suitable for the double spike method, which thus has become the favored method for correcting isotope fractionation induced in the laboratory (Skierszkan et al., 2015). Several laboratories have calibrated and adopted a ${ }^{97} \mathrm{Mo}-{ }^{100} \mathrm{Mo}$ spike to obtain $\delta^{98} \mathrm{Mo}$ data on an in-house standard solution that has a long-term external reproducibility of better than $\pm 0.12 \%$, reaching as low as $0.04 \%$ ( $2 \sigma$ ) (Siebert et al., 2001; Goldberg et al., 2013; Willbold et al., 2016). Data from molybdenite samples utilizing TIMS and a ${ }^{94} \mathrm{Mo}^{100} \mathrm{Mo}$ spike with no chemical purification yielded Mo isotope ratios with uncertainties of $0.12 \%$ /amu at the $2 \sigma$ level (Hannah et al., 2007; Wieser et al., 2007). Recently, Nagai and Yokohama (2016) utilized a ${ }^{92} \mathrm{Mo}^{97} \mathrm{Mo}^{9}{ }^{100} \mathrm{Mo}$ triple spike and N-TIMS to determine Mo isotope ratios in a standard solution with a reproducibility of $\sim 0.01 \%$ / amu at the $2 \sigma$ level (i.e., $\sim 10 \mathrm{ppm}$ on the ${ }^{96} \mathrm{Mo} /{ }^{95} \mathrm{Mo}$ ratio).

\section{CHEMICAL AND BIOLOGICAL CONTEXT}

\section{Aqueous Geochemistry}

193 In the surface environment, interest in Mo has long revolved around its dynamic redox behavior 194 (e.g., Bertine and Turekian, 1973; Morford and Emerson, 1999). Under oxygenated conditions, 195 Mo is a highly mobile and conservative element that accumulates in seawater to such an extent 196 that it is the most abundant transition metal in the oceans $\left(\sim 107 \mathrm{nmol} \mathrm{kg}^{-1}\right.$; Morris, 1975; 197 Bruland, 1983; Collier, 1985). In contrast, in $\mathrm{H}_{2} \mathrm{~S}$-bearing waters, Mo is readily removed from 198 solution, leading to pronounced sedimentary enrichments (e.g., Bertine and Turekian, 1973; 199 Emerson and Huested, 1991; Crusius et al., 1996; Scott and Lyons, 2012). This bimodal 200 behavior has made $\mathrm{Mo}$ - and its isotopes - particularly powerful for paleoredox investigations. 
This bimodality can be understood in terms of chemical speciation. Mo is easily oxidized, so that $\mathrm{Mo}(\mathrm{VI})$ species occupy the largest area of Eh-pH phase space, particularly at typical seawater and freshwater conditions (Fig. 2). Mo(VI) readily forms the oxyanion molybdate $\left(\mathrm{MoO}_{4}{ }^{2-}\right)$, which coordinates only weakly with other environmentally common inorganic ligands such as $\mathrm{Cl}^{-}$or $\mathrm{OH}^{-}$. Thus, the tetrahedrally coordinated oxyanion $\mathrm{MoO}_{4}{ }^{2-}$ is thought to dominate aqueous speciation. However, recent work suggests a significant role for $\mathrm{Mo}(\mathrm{V})$ species such as $\mathrm{MoO}_{2}{ }^{+}$(Wang et al., 2011). The potential importance of this species can be seen in Fig. 2, which compares the distribution of Mo species in Eh-pH space (a) with, and (b) without $\mathrm{MoO}_{2}{ }^{+}$. This cationic species could be important at $\mathrm{pH}<8$ in dysoxic settings, but the behavior of Mo in oxic surface waters generally fits with the low reactivity of $\mathrm{MoO}_{4}{ }^{2-}$. Organic complexes also play a role in natural environments, which has been recognized for a long time (Szilagyi, 1967; Nissenbaum and Swaine, 1976), and remains an active area of investigation (Wichard et al., 2009).

The best analogy for Mo environmental chemistry is $\mathrm{S}$, with $\mathrm{MoO}_{4}{ }^{2-}$ and $\mathrm{SO}_{4}{ }^{2-}$ having similar behaviors and distributions due to similar charges, coordination, and ionic radii as well as element redox behaviors. Not surprisingly, $\mathrm{Mo}$ and $\mathrm{SO}_{4}{ }^{2-}$ concentrations are well-correlated in surface water systems (Miller et al., 2011).

218 Other molybdate species, such as $\mathrm{HMoO}_{4}^{-}$and $\mathrm{H}_{2} \mathrm{MoO}_{4}$ ("molybdic acid"), become quantitatively important only at $\mathrm{pH}<6$ (Fig. 2), but may play a role in Mo adsorption to cationic surfaces. Aqueous polynuclear molybdate species ("polymolybdates") such as $\mathrm{Mo}_{6} \mathrm{O}_{19}{ }^{2-}$ , $\mathrm{Mo}_{7} \mathrm{O}_{24} 4^{2-}$, or $\mathrm{Mo}_{8} \mathrm{O}_{26}{ }^{4-}$ will dominate the solution at $\mathrm{pH}<8$ when Mo concentrations are $>1$ $\mathrm{mM}$, while $\mathrm{MoO}_{4}{ }^{2-}$ should dominate at all concentrations below $100 \mu \mathrm{M}$ above a pH of 4 (Baes and Mesmer, 1976). While millimolar-level Mo concentrations are rare in the environment, polymolybdates are implicated on some mineral surfaces. Such octahedrally coordinated Mo compounds may play an important role in Mo adsorption to $\mathrm{Mn}$ and $\mathrm{Fe}$ oxides, reflecting a change in Mo coordination geometry after $\mathrm{MoO}_{4}{ }^{2-}$ has been attracted to protonated oxide mineral surfaces, as discussed further below (Wasylenki et al., 2011).

In sulfidic aqueous solutions, $\mathrm{MoO}_{4}{ }^{2-}$ is progressively transformed into thiomolybdate species $\left(\mathrm{MoO}_{4-\mathrm{x}} \mathrm{S}_{\mathrm{x}}{ }^{2-}\right.$; Saxena et al., 1968; Diemann and Müller, 1973). At $\left[\mathrm{H}_{2} \mathrm{~S}\right]_{\mathrm{aq}}>11 \mu \mathrm{M}$, the stable thiomolybdate species is $\mathrm{MoS}_{4}{ }^{2-}$ (Erickson and Helz, 2000). This "switchpoint" corresponds to 22-125 $\mu \mathrm{M}$ total sulfide $\left(\sum \mathrm{S}^{2-}=\mathrm{H}_{2} \mathrm{~S}+\mathrm{HS}^{-}+\mathrm{S}^{2-}\right)$ at a $\mathrm{pH}$ of 7-8, typical of natural sulfidic waters.

238

Polynuclear Mo sulfide species including $\mathrm{Mo}_{2} \mathrm{~S}_{7}{ }^{2-}, \mathrm{Mo}_{4} \mathrm{~S}_{15}{ }^{6-}$, and $\mathrm{Mo}_{4} \mathrm{~S}_{13}{ }^{2-}$, are reported from continuous acidification experiments with molar-level thiomolybdate solutions (Saxena et al., 1968). Ultimately, the hexavalent $\mathrm{MoS}_{3}$ dominates at $\mathrm{pH}<2.4$ (Helz et al., 1996). Polynuclear Mo sulfide species have not been observed in sulfidic experiments with 40-350 $\mu \mathrm{M} \mathrm{Mo}$, and are probably irrelevant at the low Mo concentration in sulfidic aqueous environments $(<10 \mathrm{nM})$ (Vorlicek et al., 2004). 
As discussed further below, it is well-documented that Mo is rapidly removed from solution in $\mathrm{H}_{2} \mathrm{~S}$-rich waters. Early studies assumed that $\mathrm{MoS}_{2}$ precipitated via molybdate reduction in natural sulfidic systems (Amrhein et al., 1993):

$$
\mathrm{MoS}_{4}{ }^{2-}+2 \mathrm{e}^{-}+2 \mathrm{HS}^{-}+6 \mathrm{H}^{+}<=>\mathrm{MoS}_{2}+4 \mathrm{H}_{2} \mathrm{O}
$$

$$
\Delta \mathrm{G}^{0}=-314.3 \mathrm{~kJ} / \mathrm{mol}
$$

However, $\mathrm{MoS}_{2}$ precipitation is kinetically hindered in most Earth surface environments studied to date (e.g., Helz et al., 1996; Bostick et al., 2003; Chappaz et al., 2008; Dahl et al., 2013a). Instead, the chemistry of thiomolybdate species likely plays a role. In particular, these species are thought to be particle-reactive (Helz et al., 1996) and so may be removed from solution in association with sinking particulates (discussed below in section 5). Yet, there is still a large gap in our understanding of this removal process.

Mo is found as distinct Mo(IV)-sulfide compounds in unknown, submicron, dispersed forms in anoxic muds and organic-rich mudrocks (Helz et al., 1996; Bostick et al., 2003; Dahl et al., 2013a). Hence, post-thiomolybdate reactions involve a Mo reduction step. Zero-valent sulfur present in natural sulfidic environments can reduce thiomolybdate to form highly reactive Mo polysulfide anions (Vorlicek et al., 2004) that, in turn, readily adsorb onto $\mathrm{FeS}_{2}, \mathrm{FeS}$ (Bostick et al., 2003; Helz et al., 2004), and clay minerals (i.e., illite and Fe-contaminated kaolinite and montmorillonite) (Helz et al., 2004). Scavenging with particulate organic matter is indicated in experiments with sulfate reducing bacteria where Mo precipitation occurs on the periphery of cells (Biswas et al., 2009). This may also explain the general relationship between Mo and organic carbon contents in euxinic sediments (discussed further below).

More recently, it was hypothesized that Mo removal in sulfidic systems is controlled by precipitation of an $\mathrm{Fe}(\mathrm{II})-\mathrm{Mo}(\mathrm{VI})$ sulfide phase to form nanoscale mineral particles with the chemical formula $\mathrm{Fe}_{5} \mathrm{Mo}_{3} \mathrm{~S}_{14}$ (Helz et al., 2011). This Mo-Fe-S phase would be consistent with the observed association of Mo with organic matter in sediments, since Mo-Fe-sulfides may be embedded in an organic matrix (Dahl et al., 2013a). The actual removal pathway(s) remain an area for future study.

\section{Biology}

Molybdenum is the only second-row transition metal in the periodic table that is required by most living organisms (Hille, 2002). Like Fe, Mo is an essential micronutrient required by enzymes catalyzing key reactions in global C, S, and $\mathrm{N}$ metabolism (e.g., Mendel and Bittner, 2006). This capacity makes Mo an important element in biology despite its scarcity at the Earth's surface ( 1 ppm), and has presumably led to the evolution of efficient processes for Mo uptake, such as production of siderophore-like binding ligands that target Mo (e.g., Liermann et al., 2005; Bellenger et al., 2008). 
273 The reason for the critical biological role of Mo is probably due to the low reduction potentials 274 of several oxidation states compared with other metals (Fig. 3). The fact that multiple Mo 275 oxidation states can be accessed over a narrow range of voltages makes Mo relatively "redox 276 labile" at low environmental Eh, but it also means that the energy gain from Mo redox 277 transformations is small compared to many other elements. Therefore, unlike Fe and Mn, Mo is 278 not used as a terminal electron acceptor or donor in metabolic pathways.

279 The redox lability makes Mo well-suited as a co-factor in enzymes that catalyze redox reactions. 280 The enzymes that utilize Mo can be grouped into two broad categories: (1) the nitrogenases and 281 (2) the mononuclear Mo enzymes (Stiefel, 1997).

282 Nitrogenase is the enzyme responsible for nitrogen fixation that converts atmospheric $\mathrm{N}_{2}$ to 283 biologically-useful $\mathrm{NH}_{3}$. Biological nitrogen fixation only occurs in prokaryotes, and is essential for maintaining the nitrogen cycle on Earth. In nitrogenases, Mo sits in a multinuclear Fe-Mo-S cluster known as the FeMo-cofactor, where the six-electron transfer reduction takes place (Rees et al., 2005). Alternative nitrogenases utilizing $\mathrm{Fe}, \mathrm{W}$ or $\mathrm{V}$ in place of Mo do exist, but they are markedly less efficient (Miller and Eady, 1988; Eady, 1996).

288 The remaining Mo-containing enzymes include more than 30 distinct enzymes that govern a wide variety of bioessential redox processes of environmental, agronomic, and health relevance. Examples include nitrate reductase, sulfite oxidase, formate dehydrogenase, xanthine oxidase, DMSO reductase, and aldehyde oxidase (Hille, 1996; Stiefel, 1997). These enzymes are not confined to prokaryotes, but also occur in eukaryotic organisms, including humans. They all contain the Mo cofactor (Moco), which is chemically, biochemically, and genetically distinct from the nitrogenase cofactor (FeMoco). The Moco enzymes all share common structural features with Mo situated at the active center coordinated via $S$ to one or two unusual pterin ligands ("molybdopterin" ligands) and usually one or more oxo groups, depending on the oxidation state of the Mo center. These enzymes carry out two electron transfer ( $\mathrm{O}$ transfer) reactions (Romao et al., 1997).

Molybdenum deficiency is rare, as are disorders of Mo metabolism, but symptoms may be induced in diets rich in $\mathrm{Cu}$ or $\mathrm{W}$, which are Mo antagonists. On the other hand, tetrathiomolybdate has a strong affinity for $\mathrm{Cu}$, and is an active agent for treatment of disorders of copper metabolism (Alvarez et al., 2010).

Molybdenum plays an important role in biology despite its scarcity at the Earth's surface, likely reflecting a combination of the unique chemical character of this element, evolutionary adaptation to higher Mo availability in increasingly more oxygenated oceans, or a legacy of early evolution in Mo-rich environments such as prebiotic chemical evolution in association with sulfide minerals (e.g., Crick and Orgel, 1973; Anbar and Knoll, 2002). 
Molybdenum limitation $(<5 \mathrm{nM})$ in some freshwater lakes can limit rates of nitrogen fixation and nitrate reduction when $\mathrm{NH}_{4}{ }^{+}$is unavailable and biology must rely on $\mathrm{N}_{2}$ and $\mathrm{NO}_{3}{ }^{-}$as sole $\mathrm{N}$ sources (Glass et al., 2012). Growth experiments show that $\mathrm{N}_{2}$ fixation slows down at 1-5 $\mathrm{nM}$ Mo in cyanobacteria, presumably due to the expression of high affinity ModABC $\mathrm{MoO}_{4}{ }^{2-}$ uptake systems, which are widely distributed in bacteria and archaea (Zerkle et al., 2006; Glass 313 et al., 2010).

314 It has been hypothesized that Mo concentrations in Proterozoic oceans were low enough that Mo and N could have co-limited marine primary production (Anbar and Knoll, 2002). The Mo concentration in seawater was lower in the Proterozoic, but it is unclear how this influenced marine productivity (Scott et al., 2008; Dahl et al., 2011; Reinhard et al., 2013a). Phylogenetic studies suggest that the Nif proteins necessary for $\mathrm{N}_{2}$ fixation were not present in the last universal common ancestor (LUCA). Molecular clock estimates suggest a Proterozoic origin, some 2,200-1,500 Myr ago (Raymond et al., 2003; Boyd et al., 2011; David and Alm, 2011), although a recent estimate suggests nitrogen fixing cyanobacteria diversified only $850-635 \mathrm{Myr}$ ago (Sánchez-Baracaldo et al., 2014). In contrast, the Moco enzymes are distributed widely amongst extant organisms in the tree of life and could have been present in LUCA (SchoeppCothenet et al., 2012). The Mo availability and Mo requirements of early life continue as subjects of scrutiny.

\section{FRACTIONATION FACTORS}

327 Molybdenum isotope fractionation during both abiotic and biotic chemical reactions has been 328 studied in controlled laboratory experiments, in natural systems, and in theoretical ab initio 329 calculations. Key conclusions from these studies are reviewed below.

330 The Mo isotope fractionation observed to date is mass-dependent. Mass-dependent stable isotope fractionation is fundamentally a quantum chemical phenomenon arising from differences in the zero-point energies (ZPEs) between chemical bonds that are identical except for isotopic substitution (Bigeleisen, 1947; Urey, 1947). The mass dependence of bond strengths leads to differences in reaction rate constants, which give rise to kinetic isotope effects when reactions are unidirectional or incomplete. It also leads to mass dependence of equilibrium constants, so that an isotope offset exists between the reactant and product even for a system that has had infinite time to react (e.g., White, 2015).

\section{Adsorption to Mn Oxides}


The largest Mo isotope fractionation in nature occurs during Mo adsorption onto Mn oxides in oxic seawater. This process has been studied in controlled laboratory experiments, which show that lighter Mo isotopes are preferentially adsorbed onto the mineral surface. Experiments with poorly crystalline potassium birnessite $\left(\sim \mathrm{K}_{0.5} \mathrm{Mn}^{3+} \mathrm{Mn}^{4+} \mathrm{O}_{4} \cdot 1.5 \mathrm{H}_{2} \mathrm{O}\right)$ in synthetic seawater yield a fractionation factor $\Delta^{98} \mathrm{Mo}_{\text {solution-MnOx }}=2.7 \pm 0.1 \%$ at $25^{\circ} \mathrm{C}$ (or $\left.\alpha=1.0027 ; \Delta \sim(\alpha-1) \times 1000\right)$ (Barling and Anbar, 2004; Wasylenki et al., 2008). This finding is in excellent agreement with the isotopic difference between Mo in seawater and natural ferromanganese sediments (Barling et al., 2001; Siebert et al., 2003; Arnold et al., 2004). This fractionation is only weakly dependent on temperature and ionic strength (Wasylenki et al., 2008). It follows the behavior of closedsystem equilibrium isotope exchange rather than an open-system with irreversible Rayleigh distillation (Fig. 4), suggesting that the mechanism is a reversible equilibrium isotope effect (Barling and Anbar, 2004).

Ironically, this substantial isotope fractionation appears to be decoupled from the versatile redox chemistry of Mo, and instead results from the change in Mo coordination geometry between $\mathrm{MoO}_{4}{ }^{2-}$ in oxic seawater and Mo adsorbed onto the mineral (Siebert et al., 2003; Wasylenki et al., 2011; Kashiwabara et al., 2011). Whereas $\mathrm{MoO}_{4}{ }^{2-}$ is tetrahedrally coordinated, EXAFS studies reveal that Mo on the mineral surface is present as octahedrally coordinated polymolybdate species (e.g., $\mathrm{Mo}_{6} \mathrm{O}_{19}{ }^{2-}$ ). Ab initio calculations show that Mo isotope fractionation between $\mathrm{MoO}_{4}{ }^{2-}$ and polymolybdates in solution produces the observed fractionation factor across a range of temperatures (Wasylenki et al., 2011). Mo may also exist in solution and on surfaces in other octahedrally coordinated compounds, such as $\mathrm{Mo}(\mathrm{OH})_{6}$ and $\mathrm{MoO}_{3}\left(\mathrm{H}_{2} \mathrm{O}\right)_{3}$, but these species do not reproduce the observed isotope fractionation (Liu, 2008; Oyerinde et al., 2008; Wasylenki et al., 2008).

362 The predicted concentration of polynuclear Mo species in seawater is $<10^{-41} \mathrm{M}$, corresponding to $<8000$ molecules in the entire ocean. Hence, the mechanism of Mo isotope fractionation on Mn oxide surfaces highlights the unique chemistry possible on mineral surfaces. Most likely, protonated surfaces attract negatively charged $\mathrm{MoO}_{4}{ }^{2-}$ to the mineral surface. Diprotonated 367 2011).

\section{Adsorption to Fe Oxides and Oxyhydroxides}


A range of fractionation factors occur during Mo adsorption onto magnetite, ferrihydrite, goethite, and hematite minerals, with lighter Mo isotopes preferentially removed from solution (Goldberg et al., 2009). The isotopic difference between the solid (A) and dissolved (B) phases increases at higher $\mathrm{pH}$, and also varies with mineralogy, increasing in the order magnetite $\left(\Delta^{98} \mathrm{Mo}=0.83 \pm 0.60 \%\right)<$ ferrihydrite $\left(\Delta^{98} \mathrm{Mo}=1.11 \pm 0.15 \%\right)<$ goethite $\left(\Delta^{98} \mathrm{Mo}=1.40 \pm\right.$ $0.48 \%)<$ hematite $\left(\Delta^{98} \mathrm{Mo}=2.19 \pm 0.54 \%\right.$ ) at $25^{\circ} \mathrm{C}$. The observed isotope behavior is consistent with both adsorption onto the mineral surface and adsorption of different Mo species/structures from solution. For example, both molybdate and an octrahedrally coordinated Mo compound may adsorb onto the mineral with decreasing molybdate affinity for the minerals in the order listed above. The Mo speciation in the Fe-oxyhydroxide minerals has not been directly measured.

\section{Sulfidic Species}

Molybdate reacts with hydrogen sulfide in anoxic aqueous solutions to form thiomolybdates following the reaction scheme:

$\mathrm{MoO}_{4}{ }^{2-} \rightarrow \mathrm{MoO}_{3} \mathrm{~S}^{2-} \rightarrow \mathrm{MoO}_{2} \mathrm{~S}_{2}{ }^{2-} \rightarrow \mathrm{MoOS}_{3}{ }^{2-} \rightarrow \mathrm{MoS}_{4}{ }^{2-}$

Each step involves a ligand exchange with $\mathrm{S}$ donated from $\mathrm{H}_{2} \mathrm{~S}$, and $\mathrm{O}$ inserted into $\mathrm{H}_{2} \mathrm{O}$. There is a geochemical switchpoint at $\left[\mathrm{H}_{2} \mathrm{~S}\right]_{\mathrm{aq}}=11 \mu \mathrm{M}$, above which Mo exists primarily as tetrathiomolybdate $\left(\mathrm{MoS}_{4}{ }^{2-}\right.$ ) (Erickson and Helz, 2000). The intermediate oxythiomolybdates are only minor species in solution. For example, $\mathrm{MoS}_{4}{ }^{2-}$ should account for up to $83 \%$ of the total dissolved Mo pool in the deep Black Sea, with $\mathrm{MoOS}_{3}{ }^{2-}$ being the second most abundant species (Nägler et al., 2011). The more S-rich oxythiomolybdate species are considered particle-reactive and so will be removed from solution.

Ab initio calculations indicate that there is a large isotope fractionation associated with each step in this reaction scheme (Tossell, 2005). At equilibrium, the isotopic differences calculated for the $\left(\mathrm{MoO}_{4}{ }^{2-}-\mathrm{MoO}_{2} \mathrm{~S}_{2}{ }^{2-}\right)$ pair and the $\left(\mathrm{MoO}_{4}{ }^{2-}-\mathrm{MoS}_{4}{ }^{2-}\right)$ pair at $25^{\circ} \mathrm{C}$ are $-2.4 \%$ and $-5.4 \%$, respectively (recalculated to $\delta^{98} \mathrm{Mo}$; Tossell, 2005; Nägler et al., 2011). By interpolation, the four isotope fractionation factors are $\Delta^{98} \mathrm{Mo}_{0,1}=\Delta \Delta^{98} \mathrm{Mo}_{1,2}=1.20 \%$ and $\Delta^{98} \mathrm{Mo}_{2,3}=\Delta \Delta^{98} \mathrm{Mo}_{3,4}=$ $1.50 \%$, where the subscripts $(\mathrm{x}, \mathrm{y})$ represent the number of $\mathrm{S}$ atoms in the reactant $(\mathrm{x})$ and product (y) species. The magnitude of fractionation is higher in cooler waters, e.g. $\Delta^{98} \mathrm{Mo}_{0,1}=$ $\Delta^{98} \mathrm{Mo}_{1,2}=1.40 \%$ and $\Delta{ }^{98} \mathrm{Mo}_{2,3}=\Delta^{98} \mathrm{Mo}_{3,4}=1.75 \%$ in the deep Black Sea $\left(9^{\circ} \mathrm{C}\right)$. 
Although the thiomolybdate species have not been measured separately, observations from the Black Sea, Lake Cadagno, and Kyllaren Fjord show that the sulfidic waters are $\sim 0.5 \%$ heavier than the source waters (Dahl et al., 2010a; Nägler et al., 2011; Noordmann et al., 2015). The muted fractionation relative to that predicted from $a b$ initio calculations can be reconciled if multiple oxythiomolybdate species are particle-reactive and scavenged to the sediments (Dahl et al., 2010a; Nägler et al., 2011). Indeed, controlled precipitation experiments with $\mathrm{FeS}_{2}$ show that both $\mathrm{MoOS}_{3}{ }^{2-}$ and $\mathrm{MoS}_{4}{ }^{2-}$ are particle-reactive (Vorlicek et al., 2004). Although the fractionation factors between consecutive oxythiomolybdate species in solution are large, there is little or no isotope offset expressed between sediments and the Mo source (e.g., seawater) because Mo is quantitatively scavenged from the deep waters in these restricted euxinic basins (Neubert et al., 2008; Dahl et al., 2010a; Nägler et al., 2011; Noordmann et al., 2015).

\section{Biological Processes}

412 Molybdenum assimilation in the nitrogen-fixing soil bacterium, A. Vinelandii, is associated with the preferential incorporation of lighter Mo isotopes, with a fractionation of $\Delta^{98} \mathrm{Mo}=-0.45 \%$ o (Liermann et al., 2005; Wasylenki et al., 2007). The uptake pathway involves Mo chelation by high-affinity metal-binding ligands, such as the cathecolate "molybdophore" azotochelin, where Mo sits in an octahedral coordination geometry (Bellenger et al., 2008). There are several possible fractionating steps, including Mo release from the chelate, conversion to tetrahedrally coordinated $\mathrm{MoO}_{4}{ }^{2-}$, and uptake in the periplasmic modA transporter protein. The latter is common among bacteria and archaea. Isotope fractionation could result from: 1) simple kinetic effects associated with irreversible Mo transport; 2) coordination changes during incomplete uptake or release from the chelating ligand and/or the Mo transporter protein; or 3) sorption of Mo onto the cell surface (Liermann et al., 2005; Wasylenki et al., 2007). Molybdenum adsorption onto organic matter of algal origin may cause Mo isotope fractionation with a similar isotope enrichment factor $(-0.3 \%$ ) in productive surface waters (Kowalski et al., 2013).

However, Mo isotope fractionation during uptake may not be the only biological story. Studies of the filamentous heterocystous cyanobacterium Anabaena Variabilis also show isotope fractionation between cells and media (Zerkle et al., 2011). A. Variabilis is a freshwater species with Mo-dependent enzymes capable of both $\mathrm{N}_{2}$-fixation and nitrate reduction. Heterocystous cyanobacteria are relatively rare in the modern oceans. However, several lines of evidence point to shared biochemical pathways for Mo uptake and utilization in marine and freshwater cyanobacteria (Zerkle et al., 2011). The isotope fractionation depended on the cell function. During growth on nitrate, A. Variabilis consistently produced $\Delta^{98} \mathrm{Mocells}_{\text {-media }}$ of $-0.3 \pm 0.1 \%$.

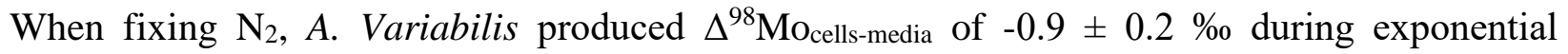
growth and $-0.5 \pm 0.1 \%$ during the stationary phase (very slow metabolic/growth rates). This variability demonstrates that Mo isotope fractionation can be more complex than a simple kinetic effect during Mo uptake because the same uptake system was likely involved in all experiments. 
437 To explain these observations, Zerkle et al. (2011) hypothesized a reaction network model that 438 assumes no isotope fractionation during Mo transport into and out of the cell, and equilibrium 439 isotope fractionation between tetrahedrally bound $\mathrm{MoO}_{4}{ }^{2-}$ in storage proteins and octahedrally 440 bound Mo in the enzymes, applying a fractionation factor $\alpha^{98 / 95}=0.9982$ derived from ab initio 441 calculations. They infer that the isotope fractionation is influenced by the relative proportion of 442 Mo bound to storage proteins vs. Mo bound to enzymes. This model indicates that the largest 443 isotope fractionation was observed during $\mathrm{N}_{2}$ fixation because at conditions of high Mo demand, 444 less Mo is bound to storage proteins (Zerkle et al., 2011).

\section{High-temperature Melt Systems}

446 Limited data are available for fractionation factors between mineral-melt pairs and silicate-metal 447 liquid pairs in high-temperature systems. Voegelin et al. (2014) estimated biotite-melt and 448 hornblende-melt fractionation factors at $\sim 700^{\circ} \mathrm{C}$ using Mo isotope data from volcanic dacite 449 (representing quenched melt) and single mineral separates. In the two dacite samples they 450 examined, biotite and hornblende had lower $\delta^{98}$ Mo than the host rock, with the largest expression 451 of isotope fractionation being $0.4 \%$ and $0.6 \%$, respectively, in the sample with the lower 452 abundance of these minerals. Hence, these are minimum fractionation factors for biotite-melt and 453 hornblende-melt pairs, respectively.

454 Fractionation of Mo isotopes during metal-liquid segregation has also been investigated 455 experimentally at $1400^{\circ} \mathrm{C}$ and $1600^{\circ} \mathrm{C}$ using a centrifuging piston cylinder, with the goal of 456 exploring the use of Mo isotopes for inferring the temperature of planetary core formation (Hin 457 et al., 2013). These experiments suggest that the fractionation factor between metal and silicate 458 liquids is insensitive to oxygen fugacity at the conditions expected for core formation, as well as 459 silicate melt composition and the $\mathrm{C}$ and $\mathrm{Sn}$ content of metallic melts. An equilibrium Mo isotope 460 fractionation factor of $0.19 \pm 0.03 \%$ and $0.12 \pm 0.02 \%$ (95\% confidence interval), favoring 461 lighter isotopes in the metallic melt, was determined for $1400^{\circ} \mathrm{C}$ and $1600^{\circ} \mathrm{C}$, respectively. From 462 these measurements, Hin et al. (2013) inferred the temperature dependence of $\Delta^{98} \mathrm{Mo}$ to be $463 \Delta \Delta^{98} \mathrm{Mo}_{\text {metal-silicate }}=-4.70( \pm 0.59) \times 10^{5} / \mathrm{T}^{2}(2 \sigma)$. Hence, resolvable Mo isotope fractionation 464 between silicate and metallic liquids is expected to occur up to $2500^{\circ} \mathrm{C}(>0.06 \%)$.

\section{MOLYBDENUM ISOTOPES IN MAJOR RESERVOIRS}

466 Meteorites 
Most iron meteorites and ordinary, enstatite, and carbonaceous chondrites have a narrow range of $\delta^{98}$ Mo (average $=0.09 \pm 0.02 \%$; 95\% confidence interval, $\mathrm{n}=12$ ) (Fig. 5; Burkhardt et al., 2014). Higher $\delta^{98} \mathrm{Mo}$ for some iron meteorites and carbonaceous chondrites may reflect evaporative loss of isotopically light Mo, although isotopic heterogeneity in the region of carbonaceous chondrite formation is also a possibility. Achondrites typically have higher $\delta^{98}$ Mo (up to $\sim 1.2 \%$ ) than chondrites because of the preferential removal of lighter Mo isotopes to metallic liquids during planetary differentiation (Burkhardt et al., 2014), as confirmed by experiments on silicate-metal isotopic partitioning (Hin et al., 2013). The temperature at which silicate and metal phases segregated during planetary differentiation can be estimated using the achondrite $\delta^{98} \mathrm{Mo}$ and the metal-silicate equilibrium fractionation factor assuming quantitative metal segregation in the core (e.g., $1800 \pm 200{ }^{\circ} \mathrm{C}$ for the moon). However, some achondrites have $\delta^{98}$ Mo that is higher than modeled for planetary core formation. This high $\delta^{98}$ Mo may reflect later processes such as high-temperature metamorphism or terrestrial weathering of fallen meteorites on Earth's surface (Burkhardt et al., 2014).

High-precision Mo isotope measurements in meteorites have revealed mass-independent variations in isotope composition arising from nucleosynthetic processes. Heavy elements such as Mo were synthesized in red giant stars (s-process) and supernovae ( $\mathrm{r}$-process and p-process) and so bulk meteorites exhibit small, but resolvable, mass-independent nucleosynthetic isotope anomalies in many elements, including Mo, that indicate presolar dust was not isotopically homogenized by high temperatures and mixing during solar system formation (Dauphas et al., 2002a, 2002b, 2004, Yin et al., 2002; Chen et al., 2004; Burkhardt et al. 2011, 2012). With respect to tracing isotopic heterogeneity within the early solar system and inferring the source of solar nebula material, the Mo isotope system is a valuable tool because four of the Mo isotopes are produced by only one nucleosynthetic process: ${ }^{92} \mathrm{Mo}$ and ${ }^{94} \mathrm{Mo}$ from the p-process; ${ }^{96} \mathrm{Mo}$ from the s-process; and ${ }^{100}$ Mo from the r-process (Arlandini et al., 1999).

492 Early studies demonstrated Mo isotope heterogeneity in solar system materials. Dauphas et al. (2002a, 2002b) reported isotopic evidence from iron meteorites, mesosiderites, pallasites, and chondrites for s-process depletion and/or enrichment in $\mathrm{r}$ - and p-process nuclides relative to terrestrial samples. Carbonaceous chondrites were found to have decoupled p- and r- process anomalies, even though both processes are associated with supernovae, implying that the feeding zone(s) of carbonaceous chondrites contained material from multiple supernova sources that had not been isotopically homogenized (Yin et al., 2002; Chen et al., 2004). 
Although one early study did not find nucleosynthetic anomalies in either primitive or differentiated meteorites (Becker and Walker 2003), likely because isotope measurements were being done at the edge of analytical capabilities at the time, recent analyses have confirmed these findings (Burkhardt et al., 2011, 2012). Notable exceptions include angrites, IAB-IIICD irons, and Martian meteorites, which have terrestrial isotopic compositions. Most other bulk meteorites exhibit depletions in Mo produced by the s-process. Carbonaceous chondrites such as Murchison seem to have multiple presolar components of variable isotopic composition, including calciumaluminum-rich inclusions predominantly enriched in r-process $\mathrm{Mo}$ and $\mathrm{SiC}$ grains enriched in sprocess Mo (Dauphas et al., 2002b; Burkhardt et al., 2011, 2012). By contrast, the Earth is enriched in s-process Mo, implying that Earth accreted from material of different isotopic composition compared with the known meteorite classes (Burkhardt et al., 2011).

The Mo isotope anomalies in bulk meteorites for each meteorite class are well-correlated with $\mathrm{Ru}$ isotope anomalies as predicted by nucleosynthesis theory, thus confirming that the observed anomalies resulted from variations in s-process contributions from low-mass AGB stars (Dauphas et al., 2004; Burkhardt et al., 2011). The magnitude of nucleosynthetic anomalies is generally greater in meteorites that are older and derived from smaller parent bodies, suggesting progressive isotopic homogenization of the solar nebula over time. Because carbonaceous chondrites have even larger nucleosynthetic Mo isotope anomalies than expected given their old age, the material that formed these primitive meteorites may have originated from further out in the solar system (where isotopic homogenization proceeded more slowly at lower temperatures) compared with other meteorites (Burkhardt et al., 2011).

\section{The Mantle and Crust}

The average $\delta^{98} \mathrm{Mo}$ of the bulk silicate Earth (BSE; crust + mantle; the mantle dominates the mass balance) is estimated to be $0.04 \pm 0.12 \%(2 \sigma)$ using four sets of komatiite samples from widely separated localities (Greber et al., 2015a). Komatiites provide a good estimate of the mantle $\delta^{98}$ Mo because the high degree of partial mantle melting necessary to form komatiitic melts results in essentially quantitative melting of sulfide minerals in the mantle source, and thus complete transfer of Mo and its isotope composition from the mantle source to melts. The excellent agreement between the $\delta^{98} \mathrm{Mo}$ of the BSE and chondritic meteorites indicates that full isotopic equilibrium was attained between the Earth's core and mantle at high temperatures $\left(>2500^{\circ} \mathrm{C}\right)$ during the moon-forming impact (Greber et al., 2015a). At such high temperatures, Mo isotope fractionation between co-existing metal and silicate phases is minimal (Hin et al., 2013).

In contrast to the isotopic homogeneity of most meteoritic and mantle materials, pronounced variability exists in the $\delta^{98} \mathrm{Mo}$ of the crust. Indeed, the entire range of $\delta^{98} \mathrm{Mo}$ observed in solid thus been devoted to explaining this isotopic variability. 
Data from subduction zones reveal that Mo isotope fractionation accompanies crustal formation. In the Mariana island arc, lavas have $\delta^{98}$ Mo up to $0.3 \%$ higher than the average mantle/BSE value, suggesting that continental crust has slightly higher $\delta^{98}$ Mo than the mantle (Freymuth et al., 2015; Greber et al., 2015a). The source of the isotopically heavy Mo may be fluids released during dehydration of the subducting slab. In the Aegean continental arc (Kos Island, Greece), fractional crystallization is suggested to have increased the $\delta^{98} \mathrm{Mo}$ of magmas as they evolved to more silica-rich compositions (Voegelin et al., 2014). The $\delta^{98}$ Mo of biotite and hornblende mineral separates suggests minimum melt-crystal fractionation factors of $0.4 \%$ and $0.6 \%$, respectively, with lighter isotopes preferentially incorporated into the fractionating crystals. Hence, fractional crystallization may explain the higher $\delta^{98}$ Mo of dacites $(0.6 \%)$ compared with basalts $(0.3 \%)$ at Kos Island. By contrast, negligible Mo isotope fractionation was observed in a suite of basalts to rhyolites in a mid-ocean ridge setting (Hekla volcano, Iceland). At the Icelandic locality, all samples yield an average $\delta^{98} \mathrm{Mo}$ of $0.10 \pm 0.05 \%$ that is indistinguishable from the mantle (Yang et al., 2015).

These observations indicate that the types of minerals crystallizing from the magma and their associated liquid-crystal fractionation factors exert some control on Mo isotope fractionation during magmatic differentiation. Amphibole and biotite did not crystallize from the largely anhydrous Hekla magmas, thus possibly explaining the lack of Mo isotope fractionation during magmatic differentiation in that mid-ocean ridge setting (Yang et al., 2015). Hence, the tectonic environment (e.g., subduction zone versus mid-ocean ridge) may influence high temperature Mo isotope fractionation via its effect on magmatic chemistry.

Least-altered mid-ocean ridge basalts from near the Mariana arc have $\delta^{98}$ Mo similar to the mantle, suggesting that decompression partial melting in the upper mantle is not accompanied by appreciable Mo isotope fractionation (Freymuth et al., 2015). The lack of Mo isotope fractionation in anhydrous systems may thus allow Mo isotopes to serve as a tracer of parent magma composition and possibly depleted versus enriched mantle sources (e.g., from analysis of ocean island basalts; Freymuth et al., 2015; Yang et al., 2015).

Crustal sulfide minerals and organic-rich mudrocks are most likely the major host phases of Mo in Earth's crust and also hold the distinction of having the widest variability in $\delta^{98} \mathrm{Mo}$. Significant efforts have been devoted to characterizing the $\delta^{98} \mathrm{Mo}$ of crustal sulfide minerals, particularly molybdenite, because of their relevance for studies on ore mineralization. Rayleigh distillation, fluid boiling, and redox reactions are thought to be responsible for the wide variation in the $\delta^{98}$ Mo of molybdenites ( $-1.4 \%$ to $+2.5 \%$; Hannah et al., 2007; Mathur et al., 2010; Greber et al., 2011, 2014; Shafiei et al., 2015; Breillat et al., 2016). Organic-rich mudrocks are characterized by a wide range in $\delta^{98} \mathrm{Mo}$ (from about $-1.3 \%$ to $+2.5 \%$ ) that is controlled primarily by local and global ocean redox conditions, as shown by recent papers that compiled Mo isotope data for these rocks (Dahl et al., 2010b; Duan et al., 2010; Wille et al., 2013; Chen et al., 2015; Kendall et al., 2015a; Partin et al., 2015). 
574 The pronounced isotopic variability in crustal rocks makes it difficult to precisely constrain the 575 average $\delta^{98} \mathrm{Mo}$ of the upper continental crust. Voegelin et al. (2014) calculated an average $\delta^{98} \mathrm{Mo}$ 576 of $\sim 0.3 \%$ based on the limited dataset of basalts and granites. A recent compilation of nearly 400 577 molybdenite samples yielded an average of $\sim 0.3 \%$, but is associated with a large $2 \sigma(1.04 \%$ ) 578 (Breillat et al., 2016). Molybdenites crystallize from hydrothermal fluids that have isotopically 579 heavier Mo than the silica-rich magmas from which they exsolved, and thus the average $\delta^{98} \mathrm{Mo}$ 580 of molybdenites likely represents a maximum value for the average crust (Greber et al., 2014). 581 Igneous pyrites rather than molybdenites may be the most important Mo reservoir in the crust 582 (Miller et al., 2011), but inadequate data are available to quantify their isotopic composition.

583 The isotopic distribution of Mo in marine sediments has implications for crustal and mantle cycling of Mo. Deep-ocean pelagic sediments deposited from oxygenated bottom waters are enriched in isotopically light Mo whereas continental margins generally have sediments with isotopically heavier Mo because of reducing conditions in regions of high primary productivity (upwelling) or basin restriction (see the next section on the oceans). Pelagic sediments are preferentially incorporated into subduction zones compared with marginal sediments, resulting in an upper crust that is isotopically heavier compared with igneous rocks (Neubert et al., 2011; Freymuth et al., 2015).

The isotopically light Mo from subducted pelagic sediments may be returned to Earth's surface via seafloor hydrothermal systems (Neubert et al., 2011) or volcanism (Freymuth et al., 2015). High $\delta^{98}$ Mo in Mariana arc lavas may reflect Mo isotope fractionation during dehydration of the have low $\delta^{98} \mathrm{Mo}$. Incorporation of subducted oceanic lithosphere into mantle plumes may return this isotopically light Mo to Earth's surface by intraplate volcanism. This hypothesis has yet to be tested rigorously through analysis of ocean island basalts.

\section{The Oceans}

599 Global seawater has a uniform $\delta^{98}$ Mo of $2.34 \pm 0.10 \%$ (Barling et al., 2001; Siebert et al., 2003; 600 Nakagawa et al., 2012). The uniformity of this value and its magnitude can be understood in 601 terms of the ocean budget of Mo.

602 Mo is thought to have a comparatively straightforward ocean budget (Fig. 6), entering largely 603 dissolved in river waters and leaving primarily in association with authigenic Fe-Mn oxides and 604 anoxic sediments underlying oxic or anoxic waters, where hydrogen sulfide is present (Crusius et 605 al., 1996; Morford and Emerson, 1999; Scott et al., 2008; Scott and Lyons, 2012; Reinhard et al., 606 2013a). The high concentration of Mo in the modern oceans is largely dictated by the high 607 solubility of Mo phases and slow removal rate of $\mathrm{MoO}_{4}{ }^{2-}$ in the presence of dissolved $\mathrm{O}_{2}$. 608 Essentially, Mo is readily transferred from crust to oceans during oxidative weathering but, 609 because settings in which bottom water $\mathrm{O}_{2}<5 \mu \mathrm{M}$ represent only $\sim 0.3 \%$ of the modern seafloor, 610 Mo is very slowly removed from the oceans. 
611 Quantitatively, the oceanic input is entirely dominated by riverine supply with a small ( $\sim 5 \%)$ 612 contribution from low-temperature hydrothermal systems (Wheat et al., 2002; Miller et al., 2011;

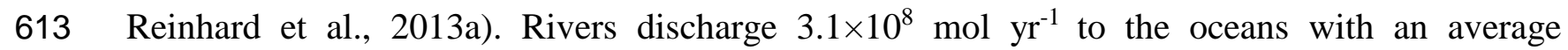
614 dissolved concentration of $8.0 \mathrm{nmol} \mathrm{kg}^{-1}$ (Miller et al., 2011). Dust and aerosols are negligible 615 fluxes (Morford and Emerson, 1999). Anthropogenic Mo contributions may also be low but are 616 not well constrained (Miller et al., 2011). From this, the oceanic residence time for Mo is 617 calculated as $\sim 40 \mathrm{kyr}$ (Miller et al., 2011), which is $\sim 40 \%$ lower than previous estimates 618 (Morford and Emerson, 1999; Scott et al., 2008). Nevertheless, this is still more than two orders 619 of magnitude higher than the ocean mixing time of $\sim 1.5 \mathrm{kyr}$ (Sarmiento and Gruber, 2006). 620 Therefore, the average Mo atom circulates the oceans $\sim 300$ times before it comes to rest in 621 sediments. Hence, the oceans are well-mixed with respect to Mo, resulting in a homogeneous 622 elemental and isotopic distribution across almost all oceans basins (Collier, 1985; Morris, 1975; 623 Nakagawa et al., 2012). The largest variations in the Mo concentration of oxygenated seawater 624 are only $\sim 5 \%$ on a salinity-normalized basis (Tuit, 2003).

625 An unusual feature of the Mo isotope system is that seawater represents the isotopically heaviest 626 Mo reservoir on Earth. This observation is readily explained by observations of modern marine 627 sediments (see below), which indicate that any expression of Mo isotope fractionation between 628 seawater and sediments always results in preferential removal of lighter Mo isotopes to 629 sediments, thus driving seawater to higher $\delta^{98}$ Mo.

630 Ocean Inputs. Surface fluids display a linear relationship between $\mathrm{Mo}$ and $\mathrm{SO}_{4}{ }^{2-}\left(\mathrm{R}^{2}=0.69\right)$, 631 implying that the predominant source of Mo is oxidative weathering of sulfide minerals and that 632 Mo is transported in the form of the hexavalent oxyanion with geochemical behavior similar to 633 that of $\mathrm{SO}_{4}{ }^{2-}$ (Miller et al., 2011).

634 Rivers are characterized by a wide range in $\delta^{98}$ Mo values between $-0.1 \%$ and $+2.3 \%$ (Archer 635 and Vance, 2008; Pearce et al., 2010a; Neubert et al., 2011; Voegelin et al., 2012; Wang et al., 636 2015). Archer and Vance (2008) calculated an average riverine $\delta^{98}$ Mo of $0.7 \%$ based on 637 analyses of waters representing $\sim 22 \%$ of global riverine discharge. This implies that modern 638 average riverine $\delta^{98} \mathrm{Mo}$ is higher than the eroding upper continental crust and BSE (Archer and 639 Vance, 2008; Neubert et al., 2011). 
Multiple mechanisms have been suggested to explain the isotopic fractionation between rivers and the eroding upper crust. During weathering, isotopically light Mo can be adsorbed to residual 642 phases in soils that have experienced net Mo loss relative to the original bedrock (Archer and 643 Vance, 2008; Pearce et al., 2010a; Liermann et al., 2011; Siebert et al., 2015; Wang et al., 2015). 644 Organic-rich soils may have a net gain in Mo with higher $\delta^{98}$ Mo compared to the original 645 bedrock (Siebert et al., 2015). However, if all Mo in soils is ultimately released to rivers, then long-term Mo isotope fractionation between the eroding upper crust and rivers should not occur (Dahl et al., 2011; Neubert et al., 2011). Adsorption of isotopically light Mo to river particulates is probably of minor importance given that most Mo is dissolved in solution (Archer and Vance, 2008; Wang et al., 2015). Desorption of isotopically light Mo from particulates may occur in some estuaries (Pearce et al., 2010a) whereas in others some isotopically light Mo may be retained in estuarine sediments, causing the release of isotopically heavy Mo to the oceans (Rahaman et al., 2014). Catchment lithology may exert significant control on the $\delta^{98} \mathrm{Mo}$ of individual rivers via incongruent dissolution during weathering of easily oxidized phases like sulfide minerals and organic matter that commonly have higher $\delta^{98}$ Mo than crustal silicate minerals (Neubert et al., 2011; Voegelin et al., 2012).

656 Low-temperature hydrothermal systems provide a subordinate contribution of Mo to the oceans (Wheat et al., 2002; Miller et al., 2011; Reinhard et al., 2013a), but this flux and its isotopic composition are poorly constrained. The lone study for the flank of the Juan de Fuca ridge suggests that Mo is released to the oceans with a $\delta^{98} \mathrm{Mo}$ of $0.8 \%$. However, it is not clear whether the isotopic signature truly reflects seawater-basalt reactions or was inherited from Mo diffusion into basaltic rocks from overlying sediments (McManus et al., 2002). High-temperature hydrothermal fluids are not a source of Mo to the oceans (Miller et al., 2011). A terrestrial hydrothermal spring from West Iceland has a $\delta^{98} \mathrm{Mo}$ of $-3.5 \%$ but the reason for this exceptionally light isotopic signature is not known (Pearce et al., 2010a).

Ocean Outputs. Significant Mo isotope fractionation occurs in the marine environment during removal to sediments (Fig. 7). To first order, the magnitude of Mo isotope fractionation between seawater and sediments correlates with the redox state of the local depositional environment. Well-oxygenated settings are characterized by the largest Mo isotope fractionations, whereas the most reducing conditions (associated with intense water column euxinia in restricted basins) may result in direct capture of seawater $\delta^{98}$ Mo by organic-rich sediments. Depositional environments of intermediate redox state have a wide range in $\delta^{98} \mathrm{Mo}$. In addition to redox conditions, other factors may affect the $\delta^{98} \mathrm{Mo}$ of sediments, such as the operation of a Fe-Mn particulate shuttle (Herrmann et al., 2012; Scholz et al., 2013). Careful consideration of local depositional conditions is important for proper application of Mo isotopes in ancient sedimentary rocks as an ocean paleoredox proxy. The three major types of sedimentary sinks, and their isotope systematics, are summarized below. 
The euxinic sink. The geochemical behavior of Mo changes sharply in $\mathrm{H}_{2} \mathrm{~S}$-bearing systems, so much that it has been likened to a "geochemical switch" (Helz et al., 1996; Erickson and Helz, 2000). This change is seen in the concentration depth profiles of these elements in the Black Sea and other restricted sulfidic basins (Fig. 8) (Emerson and Huested, 1991; Neubert et al., 2008; Dahl et al., 2010a; Helz et al. 2011; Noordmann et al., 2015). For example, in the Black Sea, oxygenated surface waters give way to deeper anoxic waters at $\sim 100 \mathrm{~m}$, with $\left[\mathrm{H}_{2} \mathrm{~S}\right]_{\mathrm{aq}}>11 \mu \mathrm{M}$ below $\sim 400 \mathrm{~m}$ water depth. The total Mo concentration across this redox transition declines from $\sim 40 \mathrm{nmol} \mathrm{kg}^{-1}$ at the surface to $\sim 3 \mathrm{nmol} \mathrm{kg}{ }^{-1}$ below the chemocline (Emerson and Huested, 1991; Nägler et al., 2011).

In euxinic settings, removal of Mo from the water column leads to strong Mo enrichments in the underlying sediments relative to its average crustal abundance of $\sim 1-2 \mathrm{ppm}$. The magnitude of this enrichment depends on Mo availability in the euxinic water column (Algeo and Lyons, 2006). In relatively unrestricted ocean settings, Mo removal to euxinic sediments is readily balanced by Mo recharge to the deep waters, resulting in high Mo enrichments (often $>100 \mathrm{ppm}$ ) in sediments (Scott and Lyons, 2012). By contrast, euxinic sediments in highly restricted basins with slow rates of deepwater renewal (including the Black Sea), euxinic sediments deposited rapidly (high sedimentation rates), and intermittently euxinic sediments typically have more modest Mo enrichments of $25-100$ ppm (Scott and Lyons, 2012).

Particle scavenging in the euxinic water column is widely accepted as an important Mo flux to euxinic sediments. Once the thiomolybdate switch has been achieved, Mo is scavenged by forming bonds with metal-rich particles, organic compounds, and/or iron sulfides. The relative importance of these host phases is not well understood, although pyrite was recently ruled out as a major Mo carrier (Chappaz et al., 2014). Early studies of settling particles caught in sediment traps in the anoxic part of the water column suggested that most Mo removal occurs below the sediment-water interface (Francois, 1988; Emerson and Huested, 1991; Crusius et al., 1996). However, more recent studies indicate that Mo removal can also occur within euxinic water columns (Dahl et al., 2010a; Helz et al., 2011). The particle affinity of thiomolybdates is also used to explain the general linear relationship between Mo and total organic carbon (TOC) contents in sediments. This may suggest a direct connection between Mo and settling organic particles (e.g., Brumsack and Gieskes, 1983; Algeo and Lyons, 2006). However, correlation does not mean causation. The Mo-TOC relationships may be indirect, since both organic matter and Mo preferentially accumulate in basins with higher sulfide concentrations (Helz et al., 1996).

712

Regardless of the mechanistic details, euxinic sedimentary settings account for removal of $\sim 6$ $15 \%$ of the Mo entering the oceans via rivers each year, despite sulfidic waters only covering 0.05-0.10\% of the seafloor today (Scott et al., 2008; Reinhard et al., 2013a). Paleoredox investigations suggest the euxinic sink was much greater in the past (see section 6). 
713 Global seawater $\delta^{98} \mathrm{Mo}$ is recorded by organic-rich sediments in the deep Black Sea and Kyllaren 714 fjord where bottom waters are strongly euxinic $\left(\left[\mathrm{H}_{2} \mathrm{~S}\right]_{\mathrm{aq}}>11 \mu \mathrm{M}\right], \mathrm{MoO}_{4}{ }^{2-}$ (molybdate) is 715 quantitatively converted to highly reactive $\mathrm{MoOS}_{3}{ }^{2-}$ (trithiomolybdate) and $\mathrm{MoS}_{4}{ }^{2-}$ 716 (tetrathiomolybdate), and Mo is quantitatively removed from sulfidic bottom waters (Erickson 717 and Helz, 2000; Barling et al., 2001; Arnold et al., 2004; Vorlicek et al., 2004; Neubert et al., 718 2008; Noordmann et al., 2015). The long seawater Mo residence time enables the $\delta^{98}$ Mo of 719 strongly euxinic sediments in a partially restricted marine basin like the Black Sea to be a proxy 720 for global seawater $\delta^{98}$ Mo (Barling et al., 2001; Arnold et al., 2004; Neubert et al., 2008; 721 Noordmann et al., 2015).

722 Quantitative Mo removal may not be characteristic of all basins with strongly euxinic bottom waters because the rate of Mo removal to sediments depends on other factors such as $\mathrm{pH}$ and sulfur speciation as well as $\left[\mathrm{H}_{2} \mathrm{~S}\right]_{\text {aq }}$ (Helz et al., 2011; Vorlicek et al. 2004). Non-quantitative removal of dissolved Mo will result in euxinic sediments with a lower $\delta^{98}$ Mo than global seawater (and enrichment of overlying euxinic bottom waters in isotopically heavy Mo; Nägler et al., 2011, Noordmann et al., 2015). The Mo isotope fractionation between dissolved $\mathrm{MoS}_{4}{ }^{2-}$ or $\mathrm{MoOS}_{3}{ }^{2-}$ and authigenic solid Mo may be $0.5 \pm 0.3 \%$ (Nägler et al., 2011), which is non-trivial and can lead to an overestimate of the global extent of ocean euxinia if it is incorrectly assumed that ancient euxinic organic-rich mudrocks directly recorded seawater $\delta^{98}$ Mo.

When bottom waters are intermittently euxinic or contain low $\left[\mathrm{H}_{2} \mathrm{~S}\right]_{\mathrm{aq}}(<11 \mu \mathrm{M})$, a wide range of $\delta^{98} \mathrm{Mo}(-0.6$ to $+1.8 \%)$ is observed in the underlying sediments, likely reflecting the slow and incomplete conversion of molybdate to thiomolybdates (Arnold et al., 2004; Nägler et al., 2005;

734 Neubert et al., 2008; Dahl et al. 2010a, Noordmann et al., 2015). Such conditions are 735 characteristic of less restricted continental margin basins (e.g., Baltic Sea and Cariaco Basin) as well as shallower waters proximal to the chemocline along the margins of more restricted basins (e.g., water depths of $\sim 100-400 \mathrm{~m}$ in the Black Sea). The sediment $\delta^{98}$ Mo is not well-correlated with $\left[\mathrm{H}_{2} \mathrm{~S}\right]_{\mathrm{aq}}$ at sulfide concentrations below the geochemical switchpoint of Mo. For intermittently euxinic basins, frequent periodic flushing by oxygenated seawater probably has a significant impact on sediment $\delta^{98} \mathrm{Mo}$ via the formation of Fe-Mn (oxyhydr)oxides and their reductive dissolution in anoxic sediments (Scholz et al., 2013; Noordmann et al., 2015). A FeMn shuttle is likely to be important for efficient transfer of Mo to sediments in less restricted redox-stratified basins and in oxygen minimum zones along upwelling continental margin systems where the redox cline occurs in the water column and deep water renewal times are fast enough to sustain the Fe-Mn shuttle (Algeo and Tribovillard, 2009; Scholz et al., 2013). 
However, some puzzling observations remain to be explained. For example, weakly euxinic sediments on the shallow Black Sea margin have significantly lighter $\delta^{98}$ Mo compared with the weakly euxinic sediments of the deep Cariaco Basin. In modern and ancient environments, distinguishing between the Mo isotope effects of incomplete thiomolybdate formation, the operation of an Fe-Mn shuttle, and periodic ventilation of anoxic basins is not a straightforward task. Careful comparisons with other geochemical redox proxies may narrow the range of possible mechanisms involved (e.g., Herrmann et al., 2012; Azrieli-Tal et al., 2014), but there is still no general approach for this. In such scenarios, the $\delta^{98}$ Mo of euxinic sediments is only a minimum estimate for global seawater $\delta^{98} \mathrm{Mo}$.

The oxic sink. Surprisingly in view of the stability of $\mathrm{MoO}_{4}{ }^{2-}$ in solution, Mo enrichment to concentrations of $100 \mathrm{~s}-1000 \mathrm{~s}$ of ppm, correlated with Mn content, is seen in ferromanganese oxide sediments, especially crusts, nodules, and some oxic pelagic sediments in the abyssal part of the oceans (Cronan and Tooms, 1969; Bertine and Turekian, 1973; Calvert and Price, 1977; Cronan, 1980; Calvert and Piper, 1984; Shimmield and Price, 1986). Such enrichment most likely reflects authigenic accumulation of Mo by adsorption to and/or co-precipitation with $\mathrm{Mn}$ oxide phases. This phenomenon is observed in the laboratory (Chan and Riley, 1966; Barling and Anbar, 2004; Wasylenki et al., 2008, 2011).

This removal process is associated with a large equilibrium isotope fractionation of $\sim 3 \%$ o occurring between Fe-Mn nodules or crusts $(-0.7 \%$ ) and seawater $(2.3 \%)$, in excellent agreement with experimental observations of Mo adsorption to birnessite (Fig. 4; Barling et al., 2001; Siebert et al., 2003; Barling and Anbar, 2004; Wasylenki et al., 2008; Poulson Brucker et al., 2009). A similar isotope fractionation was also inferred for hydrothermal Mn crusts (Ryukyu arc; Goto et al., 2015).

Because ferromanganese crusts and nodules accumulate very slowly and the Mo enrichments in widely disseminated pelagic sediments are small (Morford and Emerson, 1999), the Mo concentration and isotopic composition of the oceans is much more sensitive to the extent of ocean euxinia than to oxygenated conditions. As Mn oxides are buried into organic-matter containing sediments, they experience reductive dissolution and liberate adsorbed Mo into the pore waters. In the absence of $\mathrm{H}_{2} \mathrm{~S}$, Mo will diffuse into the overlying water column and thus the majority of Mo is not permanently buried, particularly in continental margin settings. In this scenario, Mn oxide-rich sediments can be considered failed sinks (e.g., Baja California; Shimmield and Price, 1986). Even though deep-sea sediments also leak Mo, these sediments are so widespread that they still constitute an important Mo sink. A range of estimates suggests that some $30-50 \%$ of the riverine Mo supply is buried via the Mn oxide pathway in deep-sea sediments (Bertine and Turekian, 1973; Morford and Emerson, 1999; Scott et al., 2008; Reinhard et al., 2013a). Hence, the oxic sink is disproportionately small compared with the euxinic sink given that $>80 \%$ and $\leq 0.1 \%$ of the seafloor is covered by well-oxygenated and euxinic waters, respectively (Reinhard et al., 2013a). 
The intermediate sink ("sulfidic at depth" - SAD). In the last decade, it has become clear that a substantial portion of Mo removal occurs neither in fully oxic nor in fully euxinic systems. Investigations of Mo in marine sediments and pore waters indicate that Mo is also removed from solution under less intensely reducing conditions (Fig. 9). Authigenic Mo enrichments occur in sediments overlain by waters in which $\mathrm{O}_{2}<10 \mu \mathrm{M}$ (Fig. 9c), where both Mn oxides and sulfate are reduced (Emerson and Huested, 1991; Crusius et al., 1996; Dean et al., 1999; Zheng et al., 2000; Nameroff et al., 2002). The sedimentary Mo enrichments in these "sulfidic at depth" systems are smaller (typically < $25 \mathrm{ppm}$ ) than in euxinic settings (Scott and Lyons, 2012; Dahl et al., 2013b). Current estimates suggest that $\sim 50-65 \%$ of oceanic Mo removal occurs in these environments (Morford and Emerson, 1999; McManus et al., 2006; Reinhard et al., 2013a).

In settings with $>10 \mu \mathrm{M}$ of $\mathrm{O}_{2}$ in the bottom waters, where $\mathrm{Mn}$ oxides form in the water column (Shaw et al., 1990), solid-phase Mo enrichment can develop in two redox zones within the sediment (Fig. 9b). First, transient authigenic Mo accumulation occurs at the upper limit of the manganiferous zone, where Mo is released to the pore fluids as Mn oxides undergo reductive dissolution. Secondly, a permanent Mo enrichment is found in the underlying sulfidic zone, where thiomolybdates can form. This two-fold maximum enrichment is exemplified in the sediments of the fjordic estuary Loch Etive in Western Scotland and in the Gulf of St. Lawrence (Malcolm, 1985; Sundby et al., 2004). At many localities in the modern oceans, the Mn-reducing zone is located in the water column and/or the sulfidic capture zone is located at a large enough depth below the sediment-water interface that only small authigenic Mo enrichments (up to $\sim 3$ ppm) are expressed in the sediments because most Mo escaped back into the water column (Fig. 9a). This occurs for example in Boston Harbor, USA, Bay of Biscay and Thau lagoon in France, and in the Californian and Mexican border basins (Zheng et al., 2000; Chaillou et al., 2002; Elbaz-Poulichet et al., 2005; Poulson et al., 2006; Siebert et al., 2006; Morford et al., 2007; Poulson Brucker et al., 2009).

The isotopic composition of Mo in anoxic sediments deposited from mildly oxygenated to anoxic (but non-sulfidic) bottom waters depends on a number of factors, including the $\mathrm{Fe}$ and Mn content of the (oxyhydr)oxides, the crystallinity of $\mathrm{Fe}$ (oxyhydr)oxides, and the amount of dissolved $\mathrm{H}_{2} \mathrm{~S}$ in sediment pore waters (Poulson Brucker et al., 2009; Goldberg et al., 2009, 2012). Goldberg et al. (2012) identified three groups: 1) Mn-rich sediments with low dissolved porewater $\mathrm{H}_{2} \mathrm{~S}\left(\delta^{98} \mathrm{Mo}=-1.0 \%\right.$ to $\left.\left.+0.4 \%\right) ; 2\right)$ Fe-rich sediments with low dissolved porewater $\mathrm{H}_{2} \mathrm{~S}\left(\delta^{98} \mathrm{Mo}=-0.5 \%\right.$ to $+2.0 \%$ ); and 3$)$ sediments with high dissolved porewater $\mathrm{H}_{2} \mathrm{~S}\left(\delta^{98} \mathrm{Mo}=\right.$ $1.6 \pm 0.2 \%$ ). The low $\delta^{98} \mathrm{Mo}$ of the first group simply reflects the large Mo isotope fractionation between seawater and Mn-rich oxides. 
818 In the second group, the most reactive and poorly crystalline Fe (oxyhydr)oxides (e.g., 819 ferrihydrite) are reduced in the Mn-reducing and upper part of the Fe reduction zones in 820 sediments. The magnitude of isotope fractionation during Mo adsorption to poorly crystalline Fe 821 (oxyhydr)oxides is smaller compared with Mn oxides (Goldberg et al., 2009), resulting in 822 sediments with $\delta^{98}$ Mo between $0.5 \%$ and $2.0 \%$. By contrast, the lower part of the Fe reduction 823 zone is characterized by sediments with lower $\delta^{98}$ Mo between $-0.5 \%$ and $+1.0 \%$ o because of a 824 larger Mo isotope fractionation during Mo adsorption to more crystalline Fe (oxyhydr)oxides 825 such as hematite and goethite (Goldberg et al., 2009).

826 The third group may be influenced by Mo isotope fractionation during formation of intermediate 827 thiomolybdates, and is represented by open-ocean sediments in continental margin settings 828 where bottom waters are $\mathrm{O}_{2}$-deficient $(<10 \mu \mathrm{M})$ and pronounced microbial $\mathrm{H}_{2} \mathrm{~S}$ production 829 occurs in sediment pore waters (Poulson et al., 2006; Siebert et al., 2006; Poulson Brucker et al., 830 2009; Goldberg et al., 2012). This group likely dominates the overall Mo isotope composition of 831 the SAD sink because the higher $\mathrm{H}_{2} \mathrm{~S}$ concentrations in pore waters promote more efficient 832 removal of Mo to sediments.

\section{Lakes}

834 The Mo isotopic composition of lakes has received less attention compared with marine systems. 835 Molybdenum enrichment processes found in sulfidic marine environments were also recognized 836 in euxinic lake settings (Dahl et al., 2010a; Helz et al., 2011). Smaller Mo enrichments were 837 found in the seasonally dysoxic Castle Lake in California (Glass et al., 2013). Using sediment 838 cores from lakes in Sweden and Russia, Malinovsky et al. (2007) showed that lower $\delta^{98}$ Mo in 839 lake sediments is generally associated with deposition from oxygenated bottom waters whereas 840 higher $\delta^{98}$ Mo occurs in sediments deposited from anoxic bottom waters. This behavior was also 841 observed in two lakes in eastern Canada (Chappaz et al., 2012). Dahl et al. (2010a) examined in 842 detail the Mo isotope budget of meromictic Lake Cadagno in Switzerland to better understand 843 Mo isotope fractionation in redox-stratified water columns. The oxygenated shallow and sulfidic 844 deep parts of the lake were found to have distinctive $\delta^{98}$ Mo ( $0.8 \%$ and $1.7 \%$, respectively) in 845 part because of two different Mo sources to the lake (riverine inputs and groundwater at $0.8 \%$ 846 and $1.4 \%$, respectively). The higher $\delta^{98}$ Mo of the sulfidic deep waters $(1.7 \%$ ) compared with the 847 groundwater source (1.4\%) suggests that removal of isotopically light Mo to sediments enriched 848 the sulfidic deep waters in isotopically heavy Mo. 
850 Observations from modern environments (e.g., Emerson and Huested, 1991; Crusius et al., 1996; Helz et al., 1996; Morford and Emerson, 1999; Erickson and Helz, 2000; Zheng et al., 2000; Morford et al., 2005; Algeo and Lyons, 2006; Algeo and Tribovillard, 2009; Scott and Lyons, 2012; Dahl et al. 2013b) have led to the use of Mo concentrations in sediments as a tracer of local ocean redox conditions and the degree of water mass restriction between a local sedimentary basin and the open ocean during deposition. The Mo concentration of euxinic organic-rich mudrocks (ORMs) deposited in unrestricted or weakly restricted sedimentary basins has been used to obtain a first-order estimate of the global seawater Mo concentration and thus the extent of atmosphere-ocean oxygenation (e.g., Scott et al., 2008; Reinhard et al., 2013a). For similar reasons, it was logical to also explore the use of Mo isotopes in ORMs as an ocean redox proxy (Barling et al., 2001; Siebert et al., 2003; Arnold et al., 2004). This approach has now been extended to chemical sedimentary rocks, notably carbonates, phosphorites, and iron formations (Voegelin et al., 2009; Wen et al., 2011; Baldwin et al., 2013). The discovery that both local and global ocean redox conditions control the $\delta^{98} \mathrm{Mo}$ of marine sediments has led to ocean paleoredox studies being the most prominent application of the Mo stable isotope system.

\section{Local Depositional Conditions}

866
Building upon observations of modern environments (described in section 5), the Mo isotope composition of sediments scales with the degree of anoxia in the local depositional environment (Fig. 7). This means that the $\delta^{98} \mathrm{Mo}$ of ancient ORMs may be used to infer local bottom water redox conditions at different locations in the world if seawater $\delta^{98}$ Mo is known. Such an approach is possible for the past $\sim 60 \mathrm{Myr}$ when seawater $\delta^{98} \mathrm{Mo}$ was generally constant and close to the modern-day value of 2.3\% - as inferred from Pacific and Atlantic Fe-Mn crusts (at a temporal resolution of 1-3 Ma) assuming a constant isotopic offset of $\sim 3 \%$ between these sedimentary materials and the contemporaneous open ocean (Siebert et al., 2003).

Given that the $\delta^{98} \mathrm{Mo}$ of ORMs is influenced by both global and local ocean redox conditions, Mo isotopes should not be used alone to infer the redox state of local bottom waters when no constraint on seawater $\delta^{98} \mathrm{Mo}$ is available. Hence, Mo isotope data for older ORMs can provide insight on local depositional conditions only in combination with independent proxies for local bottom water redox conditions, particularly Mo enrichments, Mo/U and Mo/Re ratios, and sedimentary Fe speciation (Crusius et al., 1996; Morford and Emerson, 1999; Morford et al., 2005; Poulton and Canfield, 2005, 2011; Tribovillard et al., 2006, 2012; Algeo and Tribovillard, 2009; Scott and Lyons, 2012). 
The usefulness of Mo isotopes as a local redox proxy for Pleistocene-Holocene sediments can be illustrated by recent studies on the Black Sea and eastern Mediterranean Sea. As expected, older oxic-limnic sediments (Unit IIB, III) in the Black Sea record lighter $\delta^{98}$ Mo compared with more recent anoxic sediments (Unit I, IIA) (Nägler et al., 2005). Development of strongly euxinic bottom waters in the Bosporus Inlet region around 350-300 B.P. was inferred from an excursion to high $\delta^{98} \mathrm{Mo}$ (similar to modern seawater) in sediments. Arnold et al. (2012) linked this increase in bottom water sulfide concentrations to shoaling of the chemocline (by more than 65 $\mathrm{m})$ in response to water circulation and temperature changes brought on by the Little Ice Age. The $\delta^{98} \mathrm{Mo}$ of the overlying sediments declines upsection, reflecting a transition to modern welloxygenated conditions in the Bosporus Inlet region.

892 Sapropels from the eastern Mediterranean Sea exhibit more complicated stratigraphic trends in $\delta^{98}$ Mo. The youngest organic-rich sapropel (S1) has lighter $\delta^{98}$ Mo in its lower part compared with the overlying more oxygenated sediments (Reitz et al., 2007; Azrieli-Tal et al., 2014), a finding that is contrary to modern environments where more oxygenated sediments typically have lower $\delta^{98}$ Mo. Reitz et al. (2007) suggested that propagation of an oxidation front into the more reducing sapropel remobilized and transported Mo downwards in the sediment until Mo was co-precipitated with Mn oxides at the oxidation front. In contrast, Azrieli-Tal et al. (2014) used a combination of redox-sensitive metal enrichments and Fe isotope data to show that local bottom waters were euxinic during early sapropel deposition and less reducing during late sapropel deposition, and separated by a transient ventilation event associated with cold climatic conditions at $\sim 8.2 \mathrm{ka}$. The lightest $\delta^{98} \mathrm{Mo}(<-0.7 \%$ ) in the lower sapropel was suggested to reflect weakly euxinic conditions $\left(\left[\mathrm{H}_{2} \mathrm{~S}\right]_{\mathrm{aq}}<11 \mu \mathrm{M}\right)$ that caused a large Mo isotope fractionation between the sediments and overlying seawater (Azrieli-Tal et al., 2014), similar to that observed in the shallower part of the modern Black Sea (Neubert et al., 2008).

Scheiderich et al. (2010a) also used redox-sensitive metal concentrations and $\mathrm{S}$ isotope data from eight Pleistocene Mediterranean sapropels to conclude that euxinic bottom water conditions generally prevailed during sapropel deposition. The range in $\delta^{98} \mathrm{Mo}(0.3-1.8 \%)$ in the sapropels is consistent with deposition from weakly euxinic bottom waters, albeit with a smaller degree of seawater-sediment isotope fractionation compared with lower S1. Hemipelagic sediments beneath the sapropels have high $\delta^{98} \mathrm{Mo}$, in some cases exceeding modern seawater $\delta^{98} \mathrm{Mo}$, despite trace metal and $\mathrm{S}$ isotope evidence for oxygenated bottom water conditions. These observations suggest that preferential removal of isotopically light Mo to the sapropels enriched pore fluids in isotopically heavy Mo. Downward diffusion of the pore fluids would enable transfer of isotopically heavy Mo to the underlying hemipelagic sediments. 
Studies on the Paleocene-Eocene thermal maximum ( 55.9 Ma) and Eocene Thermal Maximum $2(\sim 54.1 \mathrm{Ma})$ provide an example of using Mo isotopes and redox-sensitive metal enrichments to reconstruct the development of transient euxinic conditions along ocean margins in response to hyperthermal events (Dickson and Cohen, 2012; Dickson et al., 2012). In both cases, the euxinia was fingerprinted by a stratigraphic excursion to higher Mo and Re enrichments and higher $\delta^{98} \mathrm{Mo}$ in Arctic ocean sediments. The highest $\delta^{98} \mathrm{Mo}(\sim 2.0-2.1 \%)$ approaches the modern seawater value, consistent with limited Mo isotope fractionation between seawater and sediments and thus the development of strongly euxinic bottom waters $\left(\left[\mathrm{H}_{2} \mathrm{~S}\right]_{\mathrm{aq}}>11 \mu \mathrm{M}\right)$. Dickson et al. (2014) further showed that early Eocene anoxic sediments from two continental margin sites in the Tethys Ocean were deposited from non-euxinic or intermittently euxinic bottom waters (based on Fe speciation data) and had a highest $\delta^{98}$ Mo that was $\sim 0.7 \%$ lower than the highest $\delta^{98} \mathrm{Mo}$ observed from the Arctic Ocean euxinic sediments. This $0.7 \%$ offset is similar to that observed between modern anoxic continental margin sediments and global seawater (Poulson et al., 2006; Poulson Brucker et al., 2009).

The $\delta^{98} \mathrm{Mo}$ of ORM deposited from euxinic waters (independently verified by trace metal and $\mathrm{Fe}$ speciation data) has also been used along with $\mathrm{Mo} / \mathrm{U}$ ratios to fingerprint the operation of an $\mathrm{Fe}$ Mn particulate shuttle. Specifically, low $\delta^{98} \mathrm{Mo}(<1 \%)$ and high Mo/U ratios $(\geq 3 \mathrm{x}$ the molar $\mathrm{Mo} / \mathrm{U}$ seawater ratio) in the Late Pennsylvanian Hushpuckney Shale (Midcontinent Sea, USA) and late Ediacaran Doushantuo Formation (South China) raise the possibility that an Fe-Mn particulate shuttle delivered isotopically light Mo to sediments (Herrmann et al., 2012; Kendall et al., 2015a). These examples, along with the Mediterranean sapropels, demonstrate that both weakly euxinic conditions and operation of an Fe-Mn particulate shuttle can compromise the ability of euxinic ORM to record open ocean $\delta^{98} \mathrm{Mo}$.

\section{Reconstructing the Oceanic Mo Isotope Mass Balance}

940 Global ocean redox conditions can be inferred through mass balance modelling of the oceanic Mo isotope budget. Initial models used a simple isotope mass balance involving two oceanic Mo sinks (oxic and euxinic) (Arnold et al., 2004). Modern studies now typically use more complicated models that take into account both Mo burial fluxes and the isotopic composition of three sinks (oxic, sulfidic at depth, and euxinic; see section 5) as well as the scaling of Mo burial fluxes to the size of the global seawater Mo reservoir (e.g., Dahl et al., 2011; Reinhard et al., 2013a; Chen et al., 2015). Rivers are typically assumed to be the only major source of Mo to the oceans in the Proterozoic and Phanerozoic, as they are today. This is a reasonable assumption for a world with an oxygenated atmosphere (i.e., following the Great Oxidation Event [GOE]) given that subaerial oxidative dissolution of crustal sulfide minerals is efficient even at low $\mathrm{O}_{2}$ levels (to $<0.001 \%$ and $<0.026-0.046 \%$ of present levels in the case of pyrite and molybdenite, respectively; Reinhard et al., 2009, 2013b; Greber et al., 2015b). 
952 From the perspective of the magnitude of Mo isotope fractionation in marine environments, two 953 of the three oceanic Mo sinks are easy to define. The oxic sink ( $F_{\text {Ox }}$ ) is typically associated with 954 Mo adsorption onto Mn oxides and Fe-Mn crusts beneath well-oxygenated bottom waters, which 955 is represented by a Mo isotope fractionation factor of $\sim 3 \%$. A euxinic sink ( $\left.F_{E U X}\right)$ has often been 956 used to denote environments where sediments are deposited from highly sulfidic bottom waters $957\left(\left[\mathrm{H}_{2} \mathrm{~S}\right]_{\mathrm{aq}}>11 \mu \mathrm{M}\right)$ and Mo removal from those bottom waters is nearly quantitative, thus 958 enabling preservation of seawater $\delta^{98}$ Mo in the sediments. The third sink ( $\left.F_{S A D}\right)$ has traditionally 959 been used to represent all other environments of more intermediate redox character, which range 960 from mildly oxygenated to weakly euxinic bottom waters (e.g., Kendall et al., 2009, 2011; Dahl 961 et al., 2010b, 2011). The magnitude of Mo isotope fractionation in the environments represented 962 by this third sink span the entire range between the oxic and strongly euxinic end-members. An 963 average Mo isotope fractionation of $\sim 0.7 \%$ is typically chosen to represent this sink because this 964 is the common Mo isotope offset from overlying seawater observed in continental margin 965 sediments where bottom waters are weakly oxygenated, dissolved $\mathrm{O}_{2}$ penetrates $<1 \mathrm{~cm}$ below 966 the sediment-water interface, and dissolved sulfide is present in shallow sediment pore fluids 967 (Poulson et al., 2006; Poulson Brucker et al., 2009).

968 One complication is the weakly euxinic sink (bottom water $\left[\mathrm{H}_{2} \mathrm{~S}\right]_{\mathrm{aq}}<11 \mu \mathrm{M}$ ), which is 969 characterized by a wide range of Mo isotope fractionations (up to 3\%o in the shallow Black Sea 970 near the chemocline). For mass balance modelling that integrates Mo burial fluxes with the Mo 971 isotope mass balance, it is problematic to assign weakly euxinic settings to the SAD sink because 972 both weakly and strongly euxinic settings have Mo burial fluxes that are significantly higher than 973 in non-euxinic settings (e.g., Scott et al., 2008; Reinhard et al., 2013a). Hence, a compromise is 974 to assign a small Mo isotope fractionation of $\sim 0.5 \%$ to the euxinic sink such that it represents 975 both strongly and weakly euxinic conditions (e.g., Chen et al., 2015). This Mo isotope 976 fractionation is observed in the deep weakly euxinic Cariaco Basin (Arnold et al., 2004), which 977 may be a good analogue for ancient euxinic environments. In this modelling approach, the 978 assumption that the SAD sink is dominated by the weakly oxygenated settings (Fig. 9c; where 979 Mo isotope fractionation averages 0.7\%; Poulson et al., 2006; Poulson Brucker et al., 2009) is 980 further justified because Mo burial in such settings is more efficient compared with mildly 981 oxygenated settings where dissolved sulfide occurs farther below the sediment-water interface 982 (Fig. 9b). Hence, the average $\delta^{98}$ Mo of the oxic, SAD, and euxinic sinks are $-0.7 \%$, $1.6 \%$, and $9831.8 \%$, respectively, for seawater $\delta^{98} \mathrm{Mo}=2.3 \%$.

984 The oceanic Mo isotope mass balance equation can thus be represented as:

$$
\delta_{\mathrm{RIVER}}=\mathrm{f}_{\mathrm{OX}} \delta_{\mathrm{OX}}+\mathrm{f}_{\mathrm{SAD}} \delta_{\mathrm{SAD}}+\mathrm{f}_{\mathrm{EUX}} \delta_{\mathrm{EUX}}
$$


where $\mathrm{f}=$ fraction of each sink flux relative to the total oceanic Mo burial flux $\left(f_{\text {RIVER }}=1\right), f_{\text {OX }}+$ $\mathrm{f}_{\mathrm{SAD}}+\mathrm{f}_{\mathrm{EUX}}=1$, and $\delta=\delta^{98}$ Mo. Modern budget estimates ( $\mathrm{f}_{\mathrm{OX}}=30-50 \%, \mathrm{f}_{\mathrm{SAD}}=50-65 \%, \mathrm{f}_{\mathrm{EUX}}=$ $6-15 \%)$ yield values for the average riverine input, $\delta_{\text {RIVER }}=0.5-0.9 \%$, in good agreement with the observed value of $\sim 0.7 \%$ (Morford and Emerson 1999; Archer and Vance, 2008; Scott et al. 2008, Reinhard et al., 2013a). Each $\mathrm{f}$ term in the equation can be linked to that redox setting's average global Mo burial flux, which scales with the size of the global oceanic Mo reservoir. For 992 each F term, this can be expressed as:

$$
\mathrm{F}=\mathrm{F}_{0} \times \mathrm{R} / \mathrm{R}_{0}
$$

where $\mathrm{R}$ denotes the size of the global oceanic Mo reservoir, $\mathrm{F}$ is the burial flux $\left(\mathrm{g} \mathrm{m}^{-2} \mathrm{yr}^{-1}\right)$, and the subscript 0 denotes the modern value. Each $\mathrm{f}$ term in the Mo isotope mass balance equation can be replaced by the following expression that relates each sink flux to its areal fraction:

$$
\mathrm{f}=\left[\left(\mathrm{F}_{0} \times \mathrm{R} / \mathrm{R}_{0}\right) \times\left(\mathrm{A}_{\text {TOTAL }} \times \mathrm{f}_{\mathrm{A}}\right)\right] / \mathrm{F}_{\text {RIVER }}
$$

998 where $\mathrm{f}_{\mathrm{A}}=$ fraction of seafloor represented by the sink and $\mathrm{A}=$ total seafloor area covered by the three sinks. In this way, the global seawater $\delta^{98}$ Mo can be modelled as a function of the areal extent of each sink (Dahl et al. 2011; Reinhard et al., 2013a; Chen et al., 2015). A limitation of this model is that the average Mo burial flux for each sink is based on observations from continental margin settings ( $8 \%$ of the modern seafloor), where burial fluxes are higher compared with the abyssal seafloor. Hence, the rate at which the global seawater Mo reservoir is drawn down in response to an expansion of ocean anoxia onto the abyssal seafloor will be overestimated (e.g., $\mathrm{f}_{\mathrm{A}}>8 \%$ ). Addressing this weakness would require a more complicated modelling approach that scales burial fluxes from continental margin to abyssal seafloor (cf., Dahl et al. 2011; Reinhard et al., 2013a).

1008 The mass balance model reveals that a combination of high Mo concentrations and high $\delta^{98} \mathrm{Mo}$ in 1009 ancient euxinic ORM is best interpreted as evidence for a large oceanic Mo reservoir and 1010 widespread ocean oxygenation (Fig. 10). By contrast, low Mo concentrations and low $\delta^{98} \mathrm{Mo}$ in 1011 euxinic ORM point to extensive ocean anoxia.

\section{Inferring Seawater $\delta^{98}$ Mo from Sedimentary Archives}


1013 ORMs. Application of Mo isotopes as a global ocean redox proxy depends on knowledge of 1014 ancient seawater $\delta^{98}$ Mo. The growing database of $\delta^{98}$ Mo from modern environments consistently 1015 shows that organic-rich sediments deposited from strongly euxinic bottom waters in semi1016 restricted basins are most likely to directly capture global seawater $\delta^{98} \mathrm{Mo}$ (Arnold et al., 2004; 1017 Neubert et al., 2008; Noordmann et al., 2015). Hence, ORM is the predominant lithology for 1018 inferring ancient seawater $\delta^{98} \mathrm{Mo}$. Independent indicators are used to establish that ORM were 1019 deposited from euxinic bottom waters, especially Mo enrichments and extensive pyritization of 1020 biogeochemically highly reactive $\mathrm{Fe}$ (Fe-bearing mineral phases that can react with dissolved 1021 1022 1023 1024 1025 1026 sulfide in the water column or in sediment pore waters during early diagenesis; e.g., Arnold et al., 2004; Neubert et al., 2008; Gordon et al., 2009; Pearce et al., 2010b; Dahl et al., 2010b; Scott and Lyons, 2012). The latter is identified by a combination of high ratios of highly reactive Fe to total Fe (typically >0.38; indicating anoxic bottom waters) and high ratios of pyrite Fe to highly reactive $\mathrm{Fe}(>0.7$; indicating dissolved sulfide in those anoxic waters) (Raiswell and Canfield, 1998; Poulton and Raiswell, 2002; Poulton and Canfield, 2011).

Seawater $\delta^{98}$ Mo will be directly captured by ORM if bottom water sulfide concentrations were high enough (i.e., $\left[\mathrm{H}_{2} \mathrm{~S}\right]_{\mathrm{aq}}>11 \mu \mathrm{M}$ ) to enable quantitative conversion of molybdate to highly particle-reactive Mo species, and if Mo removal from bottom waters was quantitative or nearly so. Assessing whether these conditions were met for ancient ORM is not always straightforward because local redox proxies such as Mo concentrations and Fe speciation cannot quantitatively constrain the dissolved sulfide concentration of euxinic bottom waters.

However, careful comparison of elemental and Mo isotope data can provide clues. Positively correlated stratigraphic variations in the $\delta^{98} \mathrm{Mo}$ and Mo enrichments of euxinic ORM suggest that changes in seawater $\delta^{98} \mathrm{Mo}$ are being captured because such a correlation is the expected response to changes in the global seawater Mo inventory and ocean redox conditions. By contrast, high Mo enrichments and low $\delta^{98}$ Mo (i.e., similar to igneous rocks) in ORM indicates weakly euxinic bottom waters during deposition. High Mo enrichments indicate a sizable oceanic Mo reservoir and thus a significant extent of ocean oxygenation whereas the low $\delta^{98} \mathrm{Mo}$ portrays a conflicting viewpoint of widespread ocean anoxia. This apparent contradiction can be resolved by invoking a large Mo isotope fractionation between weakly euxinic bottom waters and sediments. A combination of high Mo enrichments and low $\delta^{98}$ Mo may also be explained by operation of an Fe-Mn particulate shuttle, particularly if high Mo/U ratios are observed in ORM (Algeo and Tribovillard, 2009; Herrmann et al., 2012; Kendall et al., 2015a). In either scenario, another isotope redox proxy that is less sensitive to dissolved sulfide concentrations and the FeMn particulate shuttle is needed to infer the extent of global ocean oxygenation, such as $\mathrm{U}$ isotopes (Asael et al., 2013; Kendall et al., 2015a). 
Even if bottom waters are strongly euxinic, Mo isotope fractionation between the sediments and seawater will occur if Mo removal from bottom waters is not quantitative. In the deep Black Sea, near-quantitative removal of Mo from bottom waters is indicated by low Mo enrichments compared with TOC contents (average Mo/TOC ratio of $4.5 \mathrm{ppm} / \mathrm{wt} \%$ ) in the euxinic sediments (Algeo and Lyons, 2006; Neubert et al., 2008; Scott and Lyons, 2012). Higher Mo/TOC ratios in ORM are suggestive of non-quantitative Mo removal, which may be associated with a Mo isotope fractionation of up to $\sim 0.5 \pm 0.3 \%$ between dissolved and authigenic Mo in a strongly euxinic setting (Nägler et al., 2011). Hence, the $\delta^{98} \mathrm{Mo}$ of euxinic ORM with high Mo/TOC ratios must be regarded as a minimum value for global seawater $\delta^{98} \mathrm{Mo}$.

Fe-Mn Crusts. Hydrogenous Fe-Mn crusts have been used to trace the evolution of seawater 1059 $\delta^{98}$ Mo over the past $60 \mathrm{Myr}$ (Siebert et al., 2003). This approach takes advantage of the constant isotopic offset of $\sim 3 \%$ that is observed between modern Mn oxides and seawater. The Mo isotope record of hydrogenous Fe-Mn crusts from the Atlantic and Pacific Oceans are homogeneous and similar to modern Mn oxides, suggesting that the global ocean redox conditions during the Cenozoic Era were generally similar to today. However, the poor temporal resolution of $\mathrm{Fe}-\mathrm{Mn}$ crusts (1-3 Ma) means that short-term variations in global ocean redox conditions will not be well represented. In addition, the possibility of re-equilibration with younger seawater cannot easily be excluded. The use of Fe-Mn crusts to reconstruct seawater 1066 $\delta^{98} \mathrm{Mo}$ is also limited to the recent geological past because subduction of oceanic lithosphere has destroyed the vast majority of this record.

Carbonates. Primary carbonate precipitates and phosphorites may also directly record seawater $\delta^{98} \mathrm{Mo}$ in some cases (Voegelin et al., 2009; Wen et al., 2011; Romaniello et al., 2016). Molybdenum occurs at sub-crustal abundance in most carbonate rocks $(\ll<1 \mathrm{ppm})$, and carbonates probably constitute a negligible sink for marine Mo. In carbonate rocks, Mo may be bound to detrital silicate minerals, organic matter, sulfide minerals, and carbonate minerals. To avoid detrital material that may have a different Mo isotope composition from authigenic Mo, leaching of carbonate rocks can be done with dilute $\mathrm{HCl}$, which primarily dissolves the carbonate fraction. Otherwise, total digestion techniques can be used and the effect of the detrital component on Mo concentrations and isotopic compositions can be evaluated using immobile elements such as $\mathrm{Al}$ or Ti (Voegelin et al., 2009, 2010). 
In comparison with fine-grained siliciclastic sediments, little Mo isotope data are available for modern carbonate sediments (Voegelin et al., 2009; Romaniello et al., 2016). However, initial data are encouraging. Most modern skeletal organisms, including bivalves and gastropods, have low and strongly variable Mo contents (0.004-0.120 ppm) and isotope compositions ( $\delta^{98} \mathrm{Mo}=$ $0.07-2.19 \%$ ), suggesting a biological Mo isotope fractionation that preferentially incorporates lighter Mo isotopes into shells. Corals, however, display a nearly uniform Mo concentration (0.02-0.03 ppm) and a narrow range of $\delta^{98}$ Mo values (2.0-2.2\%) that are slightly lighter than modern seawater. This could mean that $\mathrm{MoO}_{4}{ }^{2-}$ in oxic seawater is principally incorporated directly as an impurity in the crystal lattice, but there are currently no controlled laboratory experiments to confirm this chemical pathway. Nevertheless, corals are a potential archive of $\delta^{98} \mathrm{Mo}$ in ancient seawater (Voegelin et al., 2009).

Mo isotope fractionation is also observed to be small in some non-skeletal carbonates, including ooids and in bulk carbonate sediments with high sulfide levels in pore waters (Voegelin et al., 2009; Romaniello et al., 2016). Bahamian ooid sands thought to contain pure non-skeletal calcite contain a narrow range of Mo concentrations (0.02-0.04 ppm) and $\delta^{98}$ Mo values (2.0-2.2\%) that are only slightly lower than modern seawater $(2.3 \%)$. Other ooids contain a detrital Mo component and display lower $\delta^{98}$ Mo values (Voegelin et al., 2009). Bulk carbonate sediments from shallow water settings in the Bahamas also display low Mo concentrations $(<0.2 \mathrm{ppm})$ and $\delta^{98}$ Mo that is $\sim 1 \%$ o lower than seawater when pore water sulfide concentrations are low (i.e., $\left[\mathrm{H}_{2} \mathrm{~S}\right]_{\mathrm{aq}}<20 \mu \mathrm{M}$; Romaniello et al., 2016). By contrast, high Mo concentrations (2-28 ppm) and seawater-like $\delta^{98} \mathrm{Mo}$ are found in carbonate sediments containing high levels of pore water sulfide $\left(\left[\mathrm{H}_{2} \mathrm{~S}\right]_{\mathrm{aq}}=20-300 \mu \mathrm{M}\right)$. Hence, the ability of non-skeletal carbonates to record coeval seawater $\delta^{98}$ Mo may depend on redox conditions in a fashion similar to siliciclastic sediments (Romaniello et al., 2016).

\section{Tracing Atmosphere-Ocean Oxygenation Using Mo Isotopes}

With these caveats in mind, we provide an overview of how the Mo isotope compositions of sedimentary rocks have been used to trace oxygenation of Earth's surface environment. The Mo isotope system is used in two distinct ways depending on atmospheric $\mathrm{pO}_{2}$ levels. The first is to search for evidence of free $\mathrm{O}_{2}$ in the Archean environment, with the goal of constraining the onset of oxygenic photosynthesis and the transition from an anoxic to an oxygenated atmosphere. The second is to constrain the global extent of oxygenated seafloor during various intervals in the Proterozoic and Phanerozoic, with the major goals being to infer the magnitude of oceanic anoxic events associated with major Phanerozoic mass extinctions, and to determine when Earth's oceans became predominantly oxygenated.

\section{Part 1: Searching for Free $\mathrm{O}_{2}$ in the Archean Surface Environment}


Molybdenum isotope data from Archean ORMs, carbonates, and iron formations play a prominent role in ongoing efforts to trace the dynamics of initial Earth surface oxygenation leading up to the GOE. In such studies, evidence is sought for Mo isotope fractionation in surface environments (e.g., rivers, oceans), which is manifested in the form of $\delta^{98}$ Mo values in sedimentary rocks that are higher or lower than the range observed in crustal igneous rocks. If such $\delta^{98}$ Mo values are found, an assessment is made on whether environmental $\mathrm{O}_{2}$ is likely to explain them. These assessments take into account the range of Mo isotope variations and their correlation with other geochemical redox proxies. Most studies have focused on late Archean sedimentary rocks (2.7-2.5 Ga) deposited in the Hamersley Basin, Western Australia (Duan et al., 2010; Kurzweil et al., 2015a) and the Transvaal Basin and Griqualand West Basin, South Africa (Wille et al., 2007; Voegelin et al., 2010; Czaja et al., 2012; Eroglu et al., 2015) (Fig. 11).

The 2.5 Ga Mt. McRae Shale in drillcore ABDP-9 (Hamersley Basin) has been intensively studied at high stratigraphic resolution using a diverse range of elemental and isotopic (S, Mo, U, N, Se, Os) redox proxies (Anbar et al., 2007; Kaufman et al., 2007; Garvin et al., 2009; Reinhard et al., 2009; Duan et al., 2010; Kendall et al., 2013, 2015b; Stüeken et al., 2015). In the Mt. McRae Shale, $\delta^{98}$ Mo ranges between $0.9 \%$ and 1.8\%o (Duan et al., 2010). The highest $\delta^{98}$ Mo values are found in euxinic ORM (as inferred from sedimentary Fe speciation analyses) characterized by small but distinctive Mo enrichments and isotopic evidence for a dissolved marine Mo reservoir during an episode of mild environmental oxygenation. One explanation for the high $\delta^{98}$ Mo values is the removal of isotopically light Mo to oxide minerals, thus leaving behind a dissolved pool of isotopically heavy Mo in seawater that was sequestered into euxinic sediments. Isotopic fractionation during riverine transport and in weakly euxinic settings may also have contributed to the high seawater $\delta^{98}$ Mo. Using mass balance calculations, Duan et al. (2010) showed that in a largely anoxic world, the $\delta^{98}$ Mo of a small seawater Mo reservoir is susceptible to significant modification by isotope fractionation, thus enabling high seawater $\delta^{98}$ Mo to occur without extensive oxygenation.

1139 Building upon these initial efforts, Kurzweil et al. (2015a) measured the $\delta^{98}$ Mo of ORMs, carbonates, and iron formations from the underlying 2.6-2.5 Ga stratigraphic units of the Hamersley Group. Although the stratigraphic resolution of this data is low, a general pattern of increasing $\delta^{98}$ Mo occurs upsection, peaking in the Mt. McRae Shale. This stratigraphic trend may capture an overall increase of seawater $\delta^{98} \mathrm{Mo}$ in the Hamersley Basin, but it is also possible there was only a single episode of mild environmental oxygenation during Mt. McRae time (Anbar et al., 2007; Duan et al., 2010; Kendall et al., 2015b). In sedimentary rocks older than the Mt. McRae Shale, $\delta^{98}$ Mo typically ranges between $0.5 \%$ and $1.0 \%$ and thus is either similar to 1148 or only slightly higher than igneous rock compositions, suggesting limited Mo isotope fractionation at low $\mathrm{O}_{2}$ levels. 
The Mo isotope data from ca. 2.7-2.5 Ga ORMs and carbonates of the Transvaal Basin and Griqualand West Basin, deposited on the platform and slope of the Campbellrand-Malmani carbonate platform, are also consistent with mild environmental oxygenation but yield a significantly more complex stratigraphic pattern (Wille et al., 2007; Voegelin et al., 2010; Czaja et al., 2012; Eroglu et al., 2015). Appreciable differences were commonly observed between the $\delta^{98} \mathrm{Mo}$ of ORMs and carbonates in close stratigraphic proximity. These differences may be explained by isotope fractionation associated with non-euxinic bottom water redox conditions during deposition of some ORMs (Voegelin et al., 2010) and by detrital and diagenetic modification of carbonate Mo isotope signatures (Eroglu et al., 2015). Nevertheless, the occurrence of high $\delta^{98}$ Mo values $(>1.0 \%$ ) and the association of negative Fe with positive Mo isotope signatures at multiple stratigraphic levels in the Ghaap Group are consistent with at least episodic environmental oxygenation in the vicinity of the Campbellrand-Malmani carbonate platform (Wille et al., 2007; Voegelin et al., 2010; Czaja et al., 2012; Eroglu et al., 2015). The coupled Fe-Mo isotope data suggest oxidation of $\mathrm{Fe}^{2+}$ to $\mathrm{Fe}^{3+}$ by photosynthetic $\mathrm{O}_{2}$, thus producing Fe oxides that adsorbed Mo from seawater (Czaja et al., 2012). Other geochemical data, such as Fe speciation and Re/Mo ratios, from the shallow water and slope sediments are also consistent with the episodic presence of free $\mathrm{O}_{2}$ in bottom waters (Kendall et al., 2010; Zerkle et al., 2012).

1167 Most older Archean ORMs (3.4-2.7 Ga) have minimal Mo enrichments and $\delta^{98}$ Mo values that are similar to or only slightly higher than igneous rocks. The Mo data indicate limited oxidative mobilization of Mo and minimal fractionation of Mo isotopes in the surface environment, and thus low environmental $\mathrm{O}_{2}$ levels (Siebert et al., 2005; Wille et al., 2007, 2013). High $\delta^{98}$ Mo values of up to $1.8 \%$ were found in ORM at the base of a banded iron formation sequence in the ca. 2.75 Ga Carajás Formation (southern Brazil), but post-depositional potassic metasomatism may have altered the Mo isotope compositions (Cabral et al., 2013).

1174 In contrast to the limited isotopic variation in most pre-2.7 Ga Archean ORMs, a wide range of $1175 \delta^{98} \mathrm{Mo}$ (spanning $\sim 2.5 \%$ ) is observed in the iron formations of the $2.95 \mathrm{Ga}$ Sinqeni Formation 1176 (Pongola Supergroup, South Africa) (Planavsky et al., 2014). A positive correlation is observed between $\mathrm{Fe} / \mathrm{Mn}$ ratios and $\delta^{98} \mathrm{Mo}$ in these iron formations. This observation suggests that a greater magnitude of Mo isotope fractionation (producing negative $\delta^{98} \mathrm{Mo}$ ) was associated with adsorption of Mo to Mn oxides that formed during local, transient episodes of $\mathrm{O}_{2}$ production. A similar correlation between $\mathrm{Fe} / \mathrm{Mn}$ ratios and $\delta^{98} \mathrm{Mo}$ was also observed for ca. $1.88 \mathrm{Ga}$ iron 1182 2014). 
1183 In summary, the Mo isotopic composition of Archean sedimentary rocks, together with other 1184 elemental and isotopic redox proxies, are consistent with the emerging notion of "whiffs of $\mathrm{O}_{2}$ " 1185 (i.e., episodic increases in environmental $\mathrm{O}_{2}$ levels) between the evolution of oxygenic 1186 photosynthesis and the GOE (Anbar et al., 2007; Lyons et al., 2014; Kendall et al., 2015b). For 1187 the Mo isotope record, these dynamic fluctuations in surface oxygenation are manifested in the 1188 temporal overlap of intervals containing fractionated and non-fractionated $\delta^{98}$ Mo relative to the 1189 igneous baseline.

\section{Part 2: Tracing Global Ocean Oxygenation in the post-GOE World}

1191 Next, we provide an overview of global ocean redox conditions during the Phanerozoic and 1192 Proterozoic Eons from the perspective of the Mo isotope system. The Mo isotope data from each 1193 stratigraphic section tells its own story for a specific interval of Earth history. A broader 1194 temporal perspective on changes in global ocean redox conditions since the GOE can be obtained 1195 from a compilation of Mo isotope data from euxinic ORM (Dahl et al., 2010b; Duan et al., 2010; 1196 Wille et al., 2013; Chen et al., 2015; Kendall et al., 2015a; Partin et al., 2015; Fig. 12). The 1197 maximum $\delta^{98}$ Mo found in ORM for any time interval provides the most conservative estimate of seawater $\delta^{98}$ Mo during any particular period of Earth history. Lower $\delta^{98}$ Mo values within each interval either indicate that fluctuations in seawater $\delta^{98}$ Mo occurred during that interval, or that Mo isotope fractionation occurred locally between seawater and sediments because of weakly euxinic conditions, non-quantitative removal of Mo from bottom waters, or operation of an FeMn particulate shuttle.

1203 Two observations are immediately apparent from the compilation. As expected, the Phanerozoic 1204 world overall had higher seawater $\delta^{98} \mathrm{Mo}$ and thus was more oxygenated compared with the Proterozoic (Fig. 12a), consistent with numerous other types of elemental and isotopic data from sedimentary rocks (e.g., Lyons et al., 2014). Second, the Phanerozoic witnessed oscillations in seawater $\delta^{98} \mathrm{Mo}$ in response to changes in global ocean redox conditions, including across the Proterozoic-Phanerozoic boundary and in the early Paleozoic (Dahl et al., 2010b; Chen et al., 2015; Kendall et al., 2015a). A moderate positive correlation is observed between the highest $\delta^{98} \mathrm{Mo}$ and average Mo/TOC ratios of ORM in the compilation (Fig. 12b). Such a correlation is expected because a large seawater Mo inventory, reflected by high Mo/TOC ratios in ORM, should be associated with a more oxygenated ocean floor, resulting in high seawater $\delta^{98}$ Mo. 
1213 In addition to having low $\delta^{98} \mathrm{Mo}(\leq 1.4 \%$ ), Proterozoic ORM deposited between 2050 and 640 1214 Ma are characterized by Mo/TOC ratios that are intermediate between Archean and Phanerozoic 1215 ORM (Arnold et al., 2004; Scott et al., 2008; Kendall et al., 2009, 2011, 2015a; Dahl et al., 2011; 1216 Asael et al., 2013; Reinhard et al., 2013a; Partin et al., 2015). Mass balance models suggest that 1217 the oceanic Mo reservoir was probably $<20 \%$ of today, and that the maximum extent of ocean 1218 euxinia was $<1-10 \%$ of the seafloor (Dahl et al., 2011; Reinhard et al., 2013a; Chen et al., 2015). 1219 These observations are consistent with a redox-stratified ocean structure, specifically oxygenated 1220 surface waters, euxinic mid-depth waters along productive ocean margins, and either ferruginous 1221 1222 1223 1224 or weakly oxygenated deep waters. The oceanic Mo isotope mass balance model cannot distinguish between weakly oxygenated and ferruginous sinks for Mo (both included in the SAD sink) because the magnitude of Mo isotope fractionation in such settings is similar (Goldberg et al., 2009, 2012; Dahl et al., 2010b; Kendall et al., 2015a).

We emphasize that variations in pre-Ediacaran Proterozoic seawater $\delta^{98}$ Mo were likely and that some of the maximum $\delta^{98}$ Mo may still only represent minimum values for global seawater. In particular, those intervals with high Mo enrichments (e.g., Velkerri Formation; > 100 ppm Mo; Kendall et al., 2009) likely reflect non-quantitative removal of Mo from bottom waters, suggesting that Mo isotope fractionation was expressed between seawater and sediments. Hence, it is possible that seawater $\delta^{98}$ Mo reached higher values at least sporadically between the GOE and Neoproterozoic Oxidation Event. Future work will improve the temporal resolution of the pre-Ediacaran Proterozoic database and better constrain the range of seawater $\delta^{98} \mathrm{Mo}$.

The Proterozoic-Phanerozoic transition is currently an interval of intense scrutiny. Excursions to high $\delta^{98} \mathrm{Mo}(\geq 2 \%$ ), similar to modern seawater, are observed in late Ediacaran (Kendall et al. 2015a) and early Cambrian ORM (Wille et al., 2008; Chen et al., 2015; Wen et al., 2015; Cheng et al., 2016), as well as in early Cambrian phosphorite deposits (Wen et al., 2011). Similarly, high $\delta^{98} \mathrm{Mo}$ is also observed in early Hirnantian ORMs deposited at a time of global cooling and glaciation (Zhou et al., 2012, 2015). However, lower $\delta^{98}$ Mo values $(<2 \%$ o dominate late Ediacaran and early Phanerozoic (pre-Devonian) ORMs (Lehmann et al., 2007; Wille et al., 2008; Dahl et al., 2010b; Xu et al., 2012; Zhou et al., 2012, 2015; Chen et al., 2015; Kendall et al., 2015a; Kurzweil et al., 2015b; Wen et al., 2015; Cheng et al., 2016). These low values may reflect a more deoxygenated global ocean state. Alternatively, they can be attributed to Mo isotope fractionation in the local depositional environment because of weakly euxinic or noneuxinic conditions or the operation of an active Fe-Mn particulate shuttle (e.g., Neubert et al., 2008; Gordon et al., 2009; Herrmann et al., 2012). Therefore, it is not clear if the high $\delta^{98} \mathrm{Mo}$ values represent a permanent transition to a more oxygenated ocean state, episodic oxygenation, or even an episode of expanded Mo burial with large isotope fractionations in reducing settings, specifically the weakly euxinic sink (Wille et al., 2008; Dahl et al. 2010b; Boyle et al. 2014; Chen et al. 2015; Kendall et al., 2015a). Those ORM with high Mo enrichments and high $\delta^{98} \mathrm{Mo}$ are likely to reflect, at minimum, episodes of widespread oxygenation because such conditions permit both a large oceanic Mo inventory and high seawater $\delta^{98}$ Mo. 
1252

1253

1254

1255

1256

1257

1258

1259

1260

1261

1262

1263

1264

1265

1266

1267

1268

1269

1270

1271

1272

1273

1274

1275

1276

1277

1278

1279

1280

1281

1282

1283

1284

The Mo isotope composition of ORM has been measured during biotic crises, when expansions of anoxic and sulfidic water masses are thought to have eliminated large portions of the marine fauna. The predicted consequence on seawater $\delta^{98}$ Mo during a significant expansion of ocean euxinia is a shift to lower values. Indeed, this behavior is recorded in ORMs both from the Toarcian oceanic anoxic event ( $183 \mathrm{Ma}$, Pearce et al. 2008) and from the Late Cambrian SPICE event ( $500 \mathrm{Ma}$, Gill et al. 2009). However, sediments deposited in basins where the redox conditions of the local bottom waters changed from oxygenated to euxinic can see a positive shift in $\delta^{98} \mathrm{Mo}$, due to the smaller fractionation between seawater and sediments expressed in most anoxic environments compared with oxygenated settings (e.g., Zhou et al., 2012; Proemse et al., 2013).

An example of this process is observed in sediments deposited in deep-water slope environments during the Late Permian extinction event at Buchanan Lake in the Sverdrup Basin, Arctic Canada. These sediments show a large positive shift in $\delta^{98}$ Mo values from $-2.0 \%$ to $2.2 \%$, requiring local redox changes. Moreover, the positive $\delta^{98} \mathrm{Mo}$ trend is associated with a dramatic increase to high Mo enrichments (up to $80 \mathrm{ppm}$ ), thus confirming increasingly more reducing conditions in the local basin during peak $\delta^{98}$ Mo values (Proemse et al., 2013). A similar scenario was observed in the Shangsi section, Southern China (Zhou et al. 2012). Other parts of the Sverdrup basin remained oxygenated during the mass extinction event, suggesting shallow water anoxia was not a global phenomenon. This observation is consistent with the near-modern seawater $\delta^{98}$ Mo values in sediments deposited during the local peak in reducing conditions, which suggest a substantial oxic Mo sink existed at this time (Proemse et al., 2013).

Sediments from the Late Jurassic Kimmeridge Clay Formation (155-148 Ma) show evidence for slightly more widespread euxinia than today (Pearce et al. 2010b), whereas sections from the Cenomanian-Turonian oceanic anoxic event ( 94 Ma, OAE2) suggest seawater $\delta^{98}$ Mo decreased to $\sim 1 \%$ at the peak of the event (Westermann et al., 2014; Dickson et al., 2016; Goldberg et al., 2016). Many samples from OAE2 sections have $\delta^{98}$ Mo well below the average oceanic input (i.e., < 0.6\%o), implying Mo isotope fractionation between seawater and sediments during deposition. This observation illustrates how difficult it is to record seawater $\delta^{98}$ Mo through time.

Expansions of anoxic waters during hyperthermal events is observed using local redox proxies at multiple sites during the Paleocene-Eocene thermal maximum and the early Eocene thermal maximum 2 (Dickson and Cohen, 2012; Dickson et al., 2012, 2014). The $\delta^{98}$ Mo values in these ORMs are persistently high $(2.1 \%)$ and close to modern seawater $(2.3 \%)$, suggesting that expanded ocean anoxia was limited to the short duration ( 100-200 kyr) of the warming events. 


\section{Ore Deposits}

1298

1299

1300

In summary, studies of the post-GOE world highlight that the Mo isotope paleoredox proxy can trace variations in the global extent of ocean euxinia, with a greater extent of such conditions suggested by low Mo enrichments and low $\delta^{98}$ Mo in ORM deposited from locally euxinic bottom waters. By contrast, high Mo enrichments coupled with high $\delta^{98}$ Mo values (i.e., similar to modern seawater) in ORM are a strong indicator of widespread ocean oxygenation. In some cases, it is possible that the $\delta^{98}$ Mo of euxinic ORM can be significantly lower than the seawater composition because of deposition from weakly euxinic bottom waters or the operation of an FeMn shuttle in shallower basins where the chemocline is close to the sediment-water interface. In such cases, the Mo data from ORM can provide misleading information. Hence, it is good practice to couple Mo isotope data with other paleoredox proxies to provide the most robust information on global ocean redox conditions.

\section{APPLICATION TO NATURAL RESOURCES}

Application of the Mo isotope system as a process tracer for ore deposits is in its infancy. Initial studies explored the range of Mo isotope compositions for different deposit types, and the relationship between Mo isotope variations, fractionation mechanisms, mineralization processes, and fluid sources for individual deposits.

Predictably, these initial efforts have concentrated on molybdenite (the principal ore mineral of Mo), which is approximately $60 \%$ Mo by weight and often dominates the Mo mass balance in mineralizing systems. Rhenium concentrations in molybdenites may range from a few ppm to several weight percent due to the tendency for $\mathrm{Re}^{4+}$ to substitute for $\mathrm{Mo}^{4+}$, thus enabling the use of the Re-Os geochronometer to date the timing of molybdenite crystallization and associated mineralization (Stein et al., 2001; Golden et al., 2013). Hence, Mo, S, and Re stable isotope compositions and Re-Os crystallization ages from molybdenites have potential to shed detailed insight on the alteration and mineralization processes responsible for many different types of ore deposit, including porphyry copper(-molybdenum), porphyry molybdenum, lode gold, granitepegmatite, greisen, skarn, and iron oxide copper-gold deposits (Breillat et al., 2016). A particularly attractive feature of molybdenite is the robustness of this mineral to post-ore events such as granulite facies metamorphism and intense deformation (Stein et al., 2001). 
1314 The total range of Mo isotope variation in molybdenites is $\sim 4 \%$, with isotopic compositions ranging between $-1.37 \%$ and $+2.52 \%$ (Fig. 13; Breillat et al., 2016). The average $\delta^{98}$ Mo of molybdenites is $0.29 \pm 1.04 \%$ (2SD). Significant variability in the $\delta^{98}$ Mo of molybdenites can occur for specific categories of ore deposits $(>2 \%$ ) and even within single deposits $(>1 \%$ ), including at the cm-scale (Hannah et al., 2007; Mathur et al., 2010; Greber et al., 2011, 2014; Segato et al., 2015; Shafiei et al., 2015; Breillat et al., 2016). By contrast, minimal Mo isotope variation is observed between the fractions of single coarse grains cut along and across cleavage planes for a number of molybdenites from different porphyry deposits (Segato et al., 2015). No discernible trends are observed for the $\delta^{98}$ Mo of molybdenites through time (Hannah et al., 2007; Breillat et al., 2016).

1324 1325

1326

Temperature may exert an influence on the $\delta^{98}$ Mo of molybdenites in an ore deposit. For example, molybdenite from porphyry and granite deposits, representing higher temperature crystallization, have lower $\delta^{98} \mathrm{Mo}$ (average of about $0.1 \%$ for each type; Shafiei et al., 2015; Breillat et al., 2016). By contrast, higher $\delta^{98}$ Mo is observed in molybdenites deposited by lower temperature fluids, such as in greisen and iron oxide copper-gold deposits (average of about $1.25 \%$ and $1.07 \%$, respectively; Breillat et al., 2016). However, preliminary studies reveal that Mo isotope fractionation in ore-forming systems is probably also influenced by Rayleigh distillation, fluid boiling, variations in redox conditions, and possibly molybdenite crystal structure (Hannah et al., 2007; Mathur et al., 2010; Greber et al., 2011, 2014; Shafiei et al., 2015). Significant overlap is observed in the $\delta^{98}$ Mo of molybdenites from different ore deposit types (Segato et al., 2015; Breillat et al., 2016), indicating that isotopic variations should be interpreted in the context of an individual deposit's geological history rather than the type of ore deposit it represents.

In magmatic-hydrothermal environments, $\mathrm{Mo}$ may be transported as a number of different species, such as $\mathrm{MoO}_{3}, \mathrm{MoO}_{3} \cdot \mathrm{nH}_{2} \mathrm{O}, \mathrm{MoO}_{4}{ }^{2-}, \mathrm{HMoO}_{4}^{-}, \mathrm{H}_{2} \mathrm{MoO}_{4}, \mathrm{MoO}(\mathrm{OH}) \mathrm{Cl}_{2}, \mathrm{MoO}_{2} \mathrm{Cl}_{2}$, $\mathrm{K}_{2} \mathrm{MoO}_{4}, \mathrm{KHMoO}_{4}, \mathrm{Na}_{2} \mathrm{MoO}_{4}, \mathrm{NaHMoO}_{4}$, and $\mathrm{NaHMoO}_{2} \mathrm{~S}_{2}$ (e.g., Candella and Holland, 1984; Cao, 1989; Farges et al., 2006; Rempel et al., 2006, 2009; Ulrich and Mavrogenes, 2008; Zhang et al., 2012). The dominant species involved and their associated isotope fractionations are poorly understood. Molybdenum may be transported in the vapor state as $\mathrm{MoO}_{3} \cdot \mathrm{nH}_{2} \mathrm{O}(\mathrm{Rempel}$ et al., 2006, 2009) and crystallize from the vapor upon reaction with $\mathrm{H}_{2} \mathrm{~S}$. If correct, this means that Mo isotope fractionation is possible at high temperatures. For example, Rayleigh distillation associated with molybdenite precipitation along a fracture system would result in different $\delta^{98}$ Mo for earlier (proximal) and later (distal) molybdenites (Hannah et al., 2007). The degree of covariation between Mo and $\mathrm{S}$ isotope compositions in molybdenites from a single deposit represents one test of this hypothesis because in an ore-forming system with limited Mo and $\mathrm{S}$ availability, the isotopic signatures of both elements should be positively correlated if Rayleigh distillation is the main mechanism of isotope fractionation (Hannah et al., 2007). Paired Mo and $\mathrm{S}$ isotope analyses have not yet been reported for molybdenite. 
Fluid boiling may explain some Mo isotope variations in porphyry systems because of the formation of brine and vapor components with different Mo isotope compositions (Greber et al., 2014; Shafiei et al., 2015). Lighter Mo isotopes may preferentially partition into the vapor phase whereas heavier Mo isotopes remain in the brine (Shafiei et al., 2015). In the Kerman porphyry copper deposits of Iran, a high-temperature $\left(400-600^{\circ} \mathrm{C}\right)$ brine phase deposited isotopically heavy Mo in the early stages of mineralization, whereas the vapor phase $\left(300-400^{\circ} \mathrm{C}\right)$ crystallized isotopically lighter molybdenite in the hydrothermal fracture system (Fig. 14). Hence, Shafiei et al. (2015) suggested that the $\delta^{98}$ Mo of molybdenites in a porphyry system will evolve to lower values over time and with distance from the mineralizing source. The crystal structure of the molybdenite may exert some control on the Mo isotope composition, with heavier Mo isotopes preferentially taken up by the denser $2 \mathrm{H}$ polytype compared with the less dense 3R polytype (Shafiei et al., 2015).

Redox reactions and multiple hydrothermal events may also exert a major control on Mo isotope fractionation in ore-forming systems. Molybdenites from Late Paleozoic high temperature (300$600^{\circ} \mathrm{C}$ ) quartz-molybdenite veins (Aar Massif, Switzerland) have a bimodal distribution in $\delta^{98} \mathrm{Mo}$, with peaks at $\sim 0.2 \%$ and $\sim 1.1 \%$ (Greber et al., 2011). Single-stage Rayleigh distillation is thus not the main mechanism responsible for Mo isotope fractionation. Isotopic variability in the molybdenites at both small (cm apart) and large (different hand samples) scales suggests Mo isotope fractionation was influenced by redox conditions during precipitation of molybdenite during separate episodes of fluid expulsion from an evolving magma (Greber et al., 2011).

Magmatic evolution and redox reactions may lead to higher $\delta^{98}$ Mo of molybdenites in a porphyry system over time (Greber et al., 2014). In the porphyry Questa deposit (New Mexico, U.S.A.), three major fractionation mechanisms were identified by Greber et al. (2014) that operated over a temperature range of $\sim 700$ to $350^{\circ} \mathrm{C}$. First, removal of isotopically lighter Mo into minerals during fractional crystallization can enrich the remaining melt in isotopically heavier Mo. Second, fluids exsolved from the magma are preferentially enriched in isotopically heavier Mo isotopes. Third, lighter Mo isotopes are preferentially incorporated into molybdenite during crystallization, causing the remaining fluid to have an isotopically heavier composition. Hence, later-stage molybdenites can have higher $\delta^{98}$ Mo than earlier-stage molybdenites. In the Questa deposit, this is reflected by a low $\delta^{98}$ Mo for a rhyolite formed after fluid exsolution ( $0.57 \%$ ) and successively higher median $\delta^{98}$ Mo for molybdenite in igneous-phase magmatichydrothermal breccia $(-0.29 \%)$, hydrothermal-phase magmatic-hydrothermal breccia $(-0.05 \%)$, and stockwork veins $(+0.22 \%)$ (Fig. 15; Greber et al., 2014). 
The work of Greber et al. (2014) and Shafiei et al. (2015) on porphyry deposits suggests that the $\delta^{98} \mathrm{Mo}$ of hydrothermal fluids and molybdenite may evolve to either lower or higher values over time and with distance from the mineralizing source, depending on the relative influence of various processes (fluid boiling, magmatic evolution, fluid exsolution, redox reactions) on the Mo isotope systematics of an ore-forming system. It is also possible that the spatiotemporal variations within a single deposit will be obscured by the interplay of multiple processes operating at different scales, times, and locations within the ore-forming system.

The starting Mo isotope composition of an ore-forming porphyry system can also influence the isotope compositions of molybdenites. Based on the comparison of $\mathrm{Nd}$ isotope data from magmatic rocks with Mo isotope data from molybdenites for a number of different deposits, Wang et al. (2016) suggested that porphyry systems with crustal magma sources will precipitate molybdenites with generally higher $\delta^{98}$ Mo compared with mantle-derived magmatic systems.

Molybdenum isotope studies point to the importance of redox reactions on the $\delta^{98}$ Mo of Mobearing mineral phases in low-temperature systems (Ryb et al., 2009; Greber et al., 2011; Song et al., 2011). In a Pliocene low-temperature system $\left(100-160^{\circ} \mathrm{C}\right)$ in Switzerland, molybdate may have been transported by oxidizing surface waters into brecciated rocks (Grimsel breccia) where it was reduced, leading to precipitation of Mo-bearing sulfide phases (Greber et al., 2011; the mineralogy could not be identified by the authors). The larger Mo isotope variation of $\sim 3 \%$ in the brecciated rocks compared with individual high-temperature systems may reflect a combination of lower temperature crystallization, reduction of $\mathrm{MoO}_{4}{ }^{2-}$ (an uncommon species in high-temperature systems), and multiple stages of re-dissolution and re-precipitation of Mo (Greber et al., 2011). Variable redox conditions and depositional environments (open marine versus restricted) were invoked to explain the range of Mo isotope compositions in the different orebodies of the Dajiangping pyrite deposit in China (Song et al., 2011).

A study of Mo-rich iron oxide veins by Ryb et al. (2009) revealed significant Mo isotopic variation of greater than $4 \%$ in a low temperature mineralizing system associated with the Dead Sea transform. The isotopic variation likely reflects interaction of dense evaporitic marine brines $\left(\delta^{98} \mathrm{Mo} \sim 2.3 \%\right)$ with isotopically lighter igneous and sedimentary rocks, as well as Rayleigh distillation of Mo isotopes along the brine flow path. The latter is suggested to explain Mo isotope compositions in the iron oxide veins that are higher than seawater $\delta^{98} \mathrm{Mo}$. This study demonstrates that Mo isotopes have the potential to be used as both a source and process tracer

\section{Petroleum Systems}


1418 Petroleum metal isotope geochemistry has potential for oil-source rock and oil-oil correlation 1419 and tracing petroleum generation and reservoir processes, but has not advanced beyond the 1420 exploratory stage. The Mo isotopic analysis of oils is an analytically challenging problem caused 1421 by both the highly complex nature of oil matrices as well as the low Mo concentration of oils 1422 (typically ppb to low ppm; Ventura et al., 2015). However, as shown by Ventura et al. (2015), it 1423 is expected these challenges can be circumvented for the Mo stable isotope system by using the 1424 double spike method (to minimize matrix effects) as well as high temperature and pressure 1425 microwave digestion of bulk oil samples. Another possible fruitful approach is to develop 1426 techniques to isolate the Mo-rich fraction(s) of oils (e.g., similar to asphaltene separation for Re1427 Os isotope analyses; Selby et al., 2007; Mahdaoui et al., 2013).

1428 Within a single petroleum-producing sedimentary basin, distinctive $\delta^{98}$ Mo may be preserved in 1429 different petroleum source rocks because of: a) differences in the global seawater $\delta^{98}$ Mo 1430 associated with variations in global ocean redox conditions; and/or b) differences in the 1431 magnitude of Mo isotope fractionation between local seawater and sediments caused by 1432 differences in the dissolved $\mathrm{O}_{2}$ and $\mathrm{H}_{2} \mathrm{~S}$ concentrations of local bottom waters (Ventura et al., 1433 2015). If the Mo isotope composition of oils is not affected by oil migration or reservoir 1434 processes, then it may be possible to infer the relative importance of different source rocks to oil 1435 reservoirs by comparing the Mo isotope compositions of oils and source rocks (Archer et al., 1436 2012). This approach would complement traditional methods of oil-source rock correlation using 1437 light stable isotopes and biomarkers.

1438 The Mo isotope composition of oil may not be affected by oil maturation, migration, and 1439 biodegradation on the scale of a sedimentary basin, thus raising the possibility of using Mo 1440 isotopes for oil-source rock correlation (Archer et al., 2012). However, it is not known if source 1441 rock Mo isotope compositions are transferred directly to oils. Furthermore, systematic studies are 1442 required to assess the impact on oil Mo isotope compositions by other reservoir processes such 1443 as thermochemical sulfate reduction, which is known to affect the isotopic composition of other 1444 redox-sensitive metals like Re and Os (Lillis and Selby, 2013). Ventura et al. (2015) reported a 1445 range of $\sim 1.1 \%$ (from $-0.1 \%$ to $1.0 \%$ ) for four crude oils from the Campos Basin (Brazil), but 1446 did not measure the $\delta^{98}$ Mo of the lacustrine source rocks. A total range of $\sim 1.5 \%$ was reported 1447 by Archer et al. (2012) for multiple petroleum systems.

\section{Anthropogenic Tracing}


Application of Mo isotopes as an anthropogenic tracer is confined to a small number of studies. Although anthropogenic Mo is only a small component in most lacustrine and marine settings studied to date (Dahl et al., 2010a; Scheiderich et al. 2010b; Glass et al. 2012), it has been reported from some localities (e.g., Chappaz et al., 2012; Rahaman et al., 2014). Chappaz et al. (2012) used the $\delta^{98} \mathrm{Mo}$ of sediments to fingerprint the addition of anthropogenic Mo to lakes in eastern Canada from smelting or fossil fuel combustion. In both cases, the anthropogenic source was characterized by a distinct isotope composition of $0.1 \pm 0.1 \%$. Rahaman et al. (2014) calculated that anthropogenic Mo may account for up to $27 \%$ of the dissolved Mo load in the Tapi estuary that drains into the Arabian Sea. The $\delta^{98}$ Mo of aerosols may also be useful as a tracer of urban anthropogenic emissions (Lane et al., 2013). It is expected that development of Mo isotopes as an anthropogenic tracer will accelerate in the near future.

However, distinguishing isotopically between natural and anthropogenic Mo is not always straightforward because anthropogenic source signatures may be overprinted by natural Mo isotope fractionation in the environment or because of isotopic similarities between the natural and anthropogenic sources of Mo. For example, sediments from the Baltimore Harbor (a site of smelting operations) that are enriched in Mo did not have a different $\delta^{98}$ Mo compared with uncontaminated sediments elsewhere in the Chesapeake Bay, in contrast to Os isotope data. Hence, the Mo is either not anthropogenic in origin or the natural and anthropogenic Mo have identical isotopic compositions (Scheiderich et al., 2010b). Neubert et al. (2011) could not find clear evidence for anthropogenic contamination by industry and agriculture in the concentration and isotopic composition of dissolved Mo in small rivers from India, Switzerland, and China.

1471 The Mo isotope system has matured into a valuable paleoceanographic tracer, as reflected by the 1472 large number of studies that seek to characterize local and global ocean redox conditions on the 1473 ancient Earth. Although it has long been recognized that rivers are the only major source of Mo 1474 to the modern oceans, research efforts over the past decade revealed that there are three major 1475 Mo sinks: well-oxygenated settings, sulfidic sediments overlain by weakly oxygenated bottom 1476 waters, and euxinic settings characterized by the presence of $\mathrm{H}_{2} \mathrm{~S}$ in the water column. The $1477 \delta^{98} \mathrm{Mo}$ of ancient seawater is most commonly inferred from ORM deposited from strongly 1478 euxinic bottom waters in semi-restricted marine basins. However, the difficulty of distinguishing 1479 between strongly versus weakly euxinic conditions during ORM deposition makes it challenging 1480 to confirm that such rocks do indeed record the seawater Mo isotope composition. Chemical 1481 sediments including carbonates, phosphorites, and iron formations have recently also been used 1482 to infer seawater $\delta^{98}$ Mo. 
Building from observations of Mo isotope fractionation in modern environments, a wealth of studies have sought to constrain the past extent of global ocean oxygenation from the $\delta^{98} \mathrm{Mo}$ of Proterozoic and Phanerozoic sedimentary archives, and to look for the Mo isotope expression of initial environmental oxygenation on the Archean Earth. From these studies, it is clear that both local and global conditions affect sedimentary $\delta^{98} \mathrm{Mo}$. In addition, the Mo isotope paleoredox proxy is most sensitive to the extent of ocean euxinia, rather than to oxygenated versus anoxic (euxinic and ferruginous) conditions, because the rate of Mo burial into sediments correlates with dissolved $\mathrm{H}_{2} \mathrm{~S}$ concentrations. Hence, the Mo isotope system should be used in combination with other geochemical proxies to obtain the most reliable information on paleoredox conditions. Refinements in our understanding of the modern oceanic Mo isotope budget, including the significance of biological Mo isotope fractionation and Mo isotope behavior in weakly euxinic settings, will further improve the Mo isotope paleoredox proxy.

New applications to other low-temperature systems (petroleum and anthropogenic tracing) as well as to high-temperature environments (meteorites, magmatic systems, and ore deposits) are rapidly emerging. Many basic questions have yet to be answered. Are Mo isotopes useful for oilsource rock correlation or for tracing oil reservoir processes? Can spatial variations in the Mo isotope composition of molybdenite be used as a vector to mineralization, or for fingerprinting specific processes in ore-forming systems (e.g., fluid boiling, Rayleigh distillation, redox variations, single versus multiple mineralization events)? Will Mo isotopes become a prominent anthropogenic tracer, or does natural fractionation of Mo isotopes limit this application? What more can Mo isotopes tell us about the evolution of magmatic systems, metamorphic prograderetrograde paths, mantle reservoirs and fluxes, and early solar system processes?

The Mo isotope system was part of the first wave of non-traditional stable isotope systems to be explored. We fully expect that it will continue to hold a prominent position in studies of low- and high-temperature geochemistry.

\section{Acknowledgements}

1509 Kendall acknowledges support from an NSERC Discovery Grant (RGPIN-435930). Dahl acknowledges a grant from the VILLUM Foundation (VKR023127). Anbar acknowledges support from NSF 1338810. Martin Wille, Ryan Mathur, and two anonymous reviewers provided helpful comments and suggestions. Xinming Chen produced updated Eh-pH diagrams. Alysa Segato is thanked for providing constructive suggestions on Mo isotopes in natural resources. Susan Selkirk and Xinze Lu provided valuable assistance with drafting of the figures.

\section{REFERENCES}

Algeo TJ, Lyons TW (2006) Mo-total organic carbon covariation in modern anoxic marine environments: Implications for analysis of paleoredox and paleohydrographic conditions. Paleoceanogr 21:1-23 
Algeo TJ, Tribovillard N (2009) Environmental analysis of paleoceanographic systems based on

molybdenum-uranium covariation. Chem Geol 268:211-225

Alvarez HM, Xue Y, Robinson CD, Canalizo-Hernandez MA, Marvin RG, Kelly RA, Mondragon A, Penner-Hahn JE, O'Halloran TV (2010) Tetrathiomolybdate inhibits copper trafficking proteins through metal cluster formation. Science 327:331-334

Amrhein C, Mosher PA, Brown AD (1993) The effects of redox on Mo, U, B, V, and As solubility in evaporation pond soils. Soil Science 155:249-255

Anbar AD (2004) Molybdenum stable isotopes: observations, interpretations, directions. Rev Mineral Geochem 55:429-454

Anbar AD, Knoll AH (2002) Proterozoic Ocean Chemistry and Evolution: A Bioinorganic Bridge? Science 297:1137-1142

Anbar AD, Rouxel O (2007) Metal Stable Isotopes in Paleoceanography. Ann Rev Earth Planet Sci 35:717-746

Anbar AD, Knab KA, Barling J (2001) Precise determination of mass-dependent variations in the isotopic composition of molybdenum using MC-ICPMS. Anal Chem 73:1425-1431

Anbar AD, Duan Y, Lyons TW, Arnold GL, Kendall B, Creaser RA, Kaufman AJ, Gordon GW, Scott C, Garvin J, Buick R (2007) A whiff of oxygen before the Great Oxidation Event? Science 317:1903-1906

Archer C, Vance D (2008) The isotopic signature of the global riverine molybdenum flux and anoxia in the ancient oceans. Nature Geosci 1:597-600

Archer C, Elliott T, van den Boorn S, van Bergen P (2012) Mo and Ni isotope systematics in petroleum fluids across subsurface alteration gradients. Mineral Mag 76:1433

Arlandini C, Käppeler F, Wisshak K, Gallino R, Lugaro M, Busso M, Straniero O (1999) Neutron capture in low-mass asymptotic giant branch stars: cross sections and abundance signatures, Astrophys J 525:886-900

Arnold GL, Anbar AD, Barling J, Lyons TW (2004) Molybdenum isotope evidence for widespread anoxia in Mid-Proterozoic oceans. Science 304:87-90

Arnold GL, Lyons TW, Gordon GW, Anbar AD (2012) Extreme change in sulfide concentrations in the Black Sea during the Little Ice Age reconstructed using molybdenum isotopes. Geology 40:595-598

Asael D, Tissot FLH, Reinhard CT, Rouxel O, Dauphas N, Lyons TW, Ponzevera E, Liorzou C, Chéron S (2013) Coupled molybdenum, iron and uranium stable isotopes as oceanic paleoredox proxies during the Paleoproterozoic Shunga Event. Chem Geol 362:193-210 
Azrieli-Tal I, Matthews A, Bar-Matthews M, Almogi-Labin A, Vance D, Archer C, Teutsch N 1568 (2014) Evidence from molybdenum and iron isotopes and molybdenum-uranium covariation for sulphidic bottom waters during Eastern Mediterranean sapropel S1 formation. Earth Planet Sci Lett 393:231-242

Baes CF, Mesmer RE (1976) Hydrolysis of cations. Wiley, New York

Baldwin GJ, Nägler TF, Greber ND, Turner EC, Kamber BS (2013) Mo isotopic composition of the mid-Neoproterozoic ocean: an iron formation perspective. Precambr Res 230:168-178

Barling J, Arnold GL, Anbar AD (2001) Natural mass-dependent variations in the isotopic composition of molybdenum. Earth Planet Sci Lett 193:447-457

Barling J, Anbar AD (2004) Molybdenum isotope fractionation during adsorption by manganese oxides. Earth Planet Sci Lett 217:315-329

Beard BL, Johnson CM, Skulan JL, Nealson KH, Cox L, Sun H (2003) Application of Fe isotopes to tracing the geochemical and biological cycling of Fe. Chem Geol 195:87-117

Becker H, Walker RJ (2003) Efficient mixing of the solar nebula from uniform Mo isotopic composition of meteorites. Nature 425:152-155

Bellenger JP, Wichard T, Kustka AB, Kraepiel AML (2008) Uptake of molybdenum and vanadium by a nitrogen-fixing soil bacterium using siderophores. Nature Geosci 1:243-246

Bertine K, Turekian K (1973) Molybdenum in marine deposits. Geochim Cosmochim Acta $37: 1415-1434$

Bigeleisen J (1947) Calculation of equilibrium constants for isotopic exchange reactions. J Chem Phys 15:261-267

Biswas KC, Woodards NA, Xu H, Barton LL (2009) Reduction of molybdate by sulfatereducing bacteria. Biometals 22:131-139

Bostick BC, Fendorf S, Helz GR (2003) Differential adsorption of molybdate and tetrathiomolybdate on pyrite $\left(\mathrm{FeS}_{2}\right)$. Environ Sci Technol 37:285-291

Boyd ES, Anbar AD, Miller S, Hamilton TL, Lavin M, Peters JW (2011) A late methanogen origin for molybdenum-dependent nitrogenase. Geobiol 9:221-232

Boyle RA, Dahl TW, Dale AW, Shields-Zhou GA, Zhu M, Brasier MD, Canfield DE, Lenton TM (2014) Stabilization of the coupled oxygen and phosphorus cycles by the evolution of bioturbation. Nature Geosci 7:671-676

Breillat N, Guerrot C, Marcoux E, Négrel P (2016) A new global database of $\delta^{98}$ Mo in molybdenites: a literature review and new data. J Geochem Explor 161:1-15 
1614 Bruland KW (1983) Trace elements in seawater. In: Chemical Oceanography. Riley JP, Chester

1615

1616

1617

1618

1619

1620

1621

1622

1623

1624

1625

1626

1627

1628

1629

1630

1631

1632

1633

1634

1635

1636

1637

1638

1639

1640

1641

1642

1643

1644

1645

1646

1647

1648

1649

1650

1651

1652

1653

1654

1655

1656

1657

1658

1659

1660
R (eds) Academic Press, London, p 157-220

Brumsack H, Gieskes J (1983) Interstitial water trace-metal chemistry of laminated sediments from the Gulf of California, Mexico. Mar Chem 14:89-106

Burkhardt C, Kleine T, Oberli F, Pack A, Bourdon A, Wieler R (2011) Molybdenum isotope anomalies in meteorites: constraints on solar nebula evolution and origin of the Earth. Earth Planet Sci Lett 312:390-400

Burkhardt C, Kleine T, Dauphas N, Wieler R (2012) Origin of isotopic heterogeneity in the solar nebula by thermal processing and mixing of nebular dust. Earth Planet Sci Lett 357-358:298-307

Burkhardt C, Hin RC, Kleine T, Bourdon B (2014) Evidence for Mo isotope fractionation in the solar nebula and during planetary differentiation. Earth Planet Sci Lett 391:201-211

Cabral AR, Creaser RA, Nägler T, Lehmann B, Voegelin AR, Belyatsky B, Pašava J, Seabra Gomes Jr AA, Galbiatti H, Böttcher ME, Escher P (2013) Trace-element and multi-isotope geochemistry of Late-Archean black shales in the Carajás iron-ore district, Brazil. Chem Geol 362:91-104

Calvert SE, Piper DZ (1984) Geochemistry of ferromanganese nodules from DOMES site A, Northern Equatorial Pacific: Multiple diagenetic metal sources in the deep sea. Geochim Cosmochim Acta 48:1913-1928

Calvert SE, Price NB (1977) Geochemical variation in ferromanganese nodules and associated sediments from the pacific ocean. Mar Chem 5:43-74

Candela PA, Holland HD (1984) The partitioning of copper and molybdenum between silicate melts and aqueous fluids. Geochim Cosmochim Acta 48:373-380

Cao X (1989) Solubility of molybdenite and the transport of molybdenum in hydrothermal solutions. PhD Dissertation, Iowa State University, Ames, Iowa

Chaillou, G, Anschutz P, Lavaux G, Schafer J, Blanc G (2002) The distribution of Mo, U, and $\mathrm{Cd}$ in relation to major redox species in muddy sediments of the Bay of Biscay. Mar Chem $80: 41-59$

Chan KM, Riley JP (1966) The determination of molybdenum in natural waters, silicates and biological materials. Anal Chim Acta 36:220-229

Chappaz A, Gobeil C, Tessier A (2008) Geochemical and anthropogenic enrichments of Mo in sediments from perennially oxic and seasonally anoxic lakes in Eastern Canada. Geochim Cosmochim Acta 72:170-184

Chappaz A, Lyons TW, Gordon GW, Anbar AD (2012) Isotopic fingerprints of anthropogenic molybdenum in lake sediments. Environ Sci Technol 46:10934-10940 
Chappaz A, Lyons TW, Gregory DD, Reinhard CT, Gill BC, Li C, Large RR (2014) Does pyrite act as an important host for molybdenum in modern and ancient euxinic sediments? Geochim Cosmochim Acta 126:112-122

Chen JH, Papanastassiou DA, Wasserburg GJ, Ngo HH (2004) Endemic Mo isotopic anomalies in iron and carbonaceous meteorites. Lunar Planet Sci XXXV, 1431

Chen X, Ling H-F, Vance D, Shields-Zhou GA, Zhu M, Poulton SW, Och LM, Jiang S-Y, Li D, Cremonese L, Archer C (2015) Rise to modern levels of ocean oxygenation coincided with the Cambrian radiation of animals. Nature Comm 6:7142

Cheng M, Li C, Zhou L, Algeo TJ, Zhang F, Romaniello S, Jin CS, Lei LD, Feng LJ, Jiang SY (2016) Marine Mo biogeochemistry in the context of dynamically euxinic mid-depth waters: a case study of the lower Cambrian Niutitang shales, South China. Geochim Cosmochim Acta 183:79-93

Collier RW (1985) Molybdenum in the Northeast Pacific-Ocean. Limnol Oceanogr 30:13511354

Crick FHC, Orgel LE (1973) Directed Panspermia. Icarus 19:341-346

Cronan DS (1980) Underwater minerals. Academic Press, London

Cronan DS, Tooms JS (1969) The geochemistry of manganese nodules and associated pelagic deposits from the Pacific and Indian Oceans. Deep Sea Research 16:335-359

Crusius J, Calvert S, Pedersen T, Sage D (1996) Rhenium and molybdenum enrichments in sediments as indicators of oxic, suboxic and sulfidic conditions of deposition. Earth Planet Sci Lett 145:65-78

Czaja AD, Johnson CM, Roden EE, Beard BL, Voegelin AR, Nägler TF, Beukes NJ, Wille M (2012) Evidence for free oxygen in the Neoarchean ocean based on coupled iron-molybdenum isotope fractionation. Geochim Cosmochim Acta 86:118-137

Dahl TW, Anbar AD, Gordon GW, Rosing MT, Frei R, Canfield DE (2010a) The behavior of molybdenum and its isotopes across the chemocline and in the sediments of sulfidic Lake Cadagno, Switzerland. Geochim Cosmochim Acta 74:144-163

Dahl TW, Hammarlund EU, Anbar AD, Bond DPG, Gill BC, Gordon GW, Knoll AH, Nielsen AT, Schovsbo NH, Canfield DE (2010b) Devonian rise in atmospheric oxygen correlated to the radiations of terrestrial plants and large predatory fish. Proc Natl Acad Sci USA 107:1791117915

Dahl TW, Canfield DE, Rosing MT, Frei RE, Gordon GW, Knoll AH, Anbar AD (2011) Molybdenum evidence for expansive sulfidic water masses in $\sim 750$ Ma oceans. Earth Planet Sci Lett 311:264-274 
Dahl TW, Chappaz A, Fitts JP, Lyons TW (2013a) Molybdenum reduction in a sulfidic lake: evidence from X-ray absorption fine-structure spectroscopy and implications for the Mo paleoproxy. Geochim Cosmochim Acta 103:213-231

Dahl TW, Ruhl M, Hammarlund EU, Canfield DE, Rosing MT, Bjerrum CJ (2013b) Tracing euxinia by molybdenum concentrations in sediments using handheld $\mathrm{x}$-ray fluorescence spectroscopy (HH-XRF). Chem Geol 360-361:241-251

Dauphas N, Marty B, Reisberg L (2002a) Molybdenum evidence for inherited planetary scale isotope heterogeneity of the protosolar nebula. Astrophys J 565:640-644

Dauphas N, Marty B, Reisberg L (2002b) Molybdenum nucleosynthetic dichotomy revealed in primitive meteorites. Astrophys J 569:139-142

Dauphas N, Davis AM, Marty B, Reisberg L (2004) The cosmic molybdenum-ruthenium isotope correlation. Earth Planet Sci Lett 226:465-475

David LA, Alm EJ (2011) Rapid evolutionary innovation during an Archaean genetic expansion. Nature 469:93-96

Dean W, Piper D, Peterson L (1999). Molybdenum accumulation in Cariaco basin sediment over the past 24 ky: A record of water-column anoxia and climate. Geology 27:507-510

Dickson AJ, Cohen AS (2012) A molybdenum isotope record of Eocene Thermal Maximum 2: Implications for global ocean redox during the early Eocene. Paleoceanogr 27:PA3230

Dickson AJ, Cohen AS, Coe AL (2012) Seawater oxygenation during the Paleocene-Eocene Thermal Maximum. Geology 40:639-642

Dickson AJ, Cohen AS, Coe AL (2014) Continental margin molybdenum isotope signatures from the early Eocene. Earth Planet Sci Lett 404:389-395

Dickson AJ, Jenkyns HC, Porcelli D, van den Boorn S, Idiz E (2016) Basin-scale controls on the molybdenum-isotope composition of seawater during Oceanic Anoxic Event 2 (Late Cretaceous). Geochim Cosmochim Acta 178:291-306

Diemann, E., Müller, A., 1973. Schefel- und Selenverbindungen von übergangsmetallen mit d0konfiguration (Thio and Seleno compounds of the transition metals with the d0 configuration) Coord Chem Rev 10:79-122

Duan Y, Anbar AD, Arnold GL, Lyons TW, Gordon GW, Kendall B (2010) Molybdenum isotope evidence for mild environmental oxygenation before the Great Oxidation Event. Geochim Cosmochim Acta 74:6655-6668

Eady, R.R., 1996. Structure-Function Relationships pf Alternative Nitrogenases. Chem Rev 1755 
Elbaz-Poulichet, F., Seidel, J.L., Jézéquel, D., Metzger, E., Prévot, F., Simonucci, C., Sarazin, G., Viollier, E., Etcheber, H., Jouanneau, J.-M., Weber, O., Radakovitch, O., 2005. Sedimentary record of redox-sensitive elements $(\mathrm{U}, \mathrm{Mn}, \mathrm{Mo})$ in a transitory anoxic basin (the Thau lagoon,

Emerson, S., Huested, S.S., 1991. Ocean anoxia and the concentrations of molybdenum and vanadium in seawater. Mar Chem 34:177-196

Erickson BE, Helz GR (2000) Molybdenum (VI) speciation in sulfidic waters: stability and lability of thiomolybdates. Geochim Cosmochim Acta 64:1149-1158

Eroglu S, Schoenberg R, Wille M, Beukes N, Taubald H (2015) Geochemical stratigraphy, sedimentology, and Mo isotope systematics of the ca. 2.58-2.50 Ga-old Transvaal Supergroup carbonate platform, South Africa. Precambr Res 266:27-46

Farges F, Siewert R, Ponader CW, Brown Jr GE, Pichavant M, Behrens H (2006) Structural environments around molybdenum in silicate glasses and melts. II. Effect of temperature, pressure, $\mathrm{H}_{2} \mathrm{O}$, halogens, and sulfur. Can Mineral 44:755-773

Freymuth H, Vils F, Willbold M, Taylor RN, Elliott T (2015) Molybdenum mobility and isotopic fractionation during subduction at the Mariana arc. Earth Planet Sci Lett 432:176-186

Francois, R., 1988. A study on the regulation of the concentrations of some trace metals ( $\mathrm{Rb}, \mathrm{Sr}$, $\mathrm{Zn}, \mathrm{Pb}, \mathrm{Cu}, \mathrm{V}, \mathrm{Cr}, \mathrm{Ni}, \mathrm{Mn}$ and $\mathrm{Mo}$ ) in Saanich Inlet Sediments, British Columbia, Canada. Mar Geol 83:285-308

Frausto da Silva JJ, Williams RJP (2001) The Biological Chemistry of the Elements: The Inorganic Chemistry of Life. Clarendon Press, Oxford

Fujii T, Moynier F, Telouk P, Albarède F (2006) Mass-independent isotope fractionation of molybdenum and ruthenium and the origin of isotopic anomalies in Murchison. Astrophys $\mathrm{J}$ 647:1506

Garvin J, Buick R, Anbar AD, Arnold GL, Kaufman AJ (2009) Isotopic evidence for an aerobic nitrogen cycle in the latest Archean. Science 323:1045-1048

Gill BC, Lyons TW, Dahl T, Saltzman M, Gordon G, Anbar AD (2009) Multiple geochemical proxies reveal a Late Cambrian ocean anoxic event. Geochim Cosmochim Acta 73:A436

Glass JB, Wolfe-Simon F, Anbar AD (2009) Coevolution of metal availability and nitrogen assimilation in cyanobacteria and algae. Geobiol 7:100-123

Glass J, Wolfe-Simon F, Elser J, Anbar A (2010) Molybdenum-nitrogen co-limitation in freshwater and coastal heterocystous cyanobacteria. Limnol Oceanogr 55:667-676

Glass JB, Axler RP, Chandra S, Goldman CR (2012) Molybdenum limitation of microbial nitrogen assimilation in aquatic ecosystems and pure cultures. Front Microbiol 3:1-11 
1804 Glass JB, Chappaz A, Eustis B, Heyvaert AC, Waetjen DP, Hartnett HE, Anbar AD (2013) 1805 Molybdenum geochemistry in a seasonally dysoxic Mo-limited lacustrine ecosystem. Geochim

1806

1807

1808

1809

1810

1811

1812

1813

1814

1815

1816

1817

1818

1819

1820

1821

1822

1823

1824

1825

1826

1827

1828

1829

1830

1831

1832

1833

1834

1835

1836

1837

1838

1839

1840

1841

1842

1843

1844

1845

1846

1847

1848

1849

1850
Cosmochim Acta 114:204-219.

Goldberg T, Archer C, Vance D, Poulton SW (2009) Mo isotope fractionation during adsorption to Fe (oxyhydr)oxides. Geochim Cosmochim Acta 73:6502-6516

Goldberg T, Archer C, Vance D, Thamdrup B, McAnena A, Poulton SW (2012) Controls on Mo isotope fractionations in a Mn-rich anoxic marine sediment, Gullmar Fjord, Sweden. Chem Geol 296-297:73-82

Goldberg T, Gordon G, Izon G, Archer C, Pearce CR, McManus J, Anbar AD, Rehkämper M (2013) Resolution of inter-laboratory discrepancies in Mo isotope data: an intercalibration. J Anal At Spectrom 28:724-735

Goldberg T, Poulton SW, Wagner T, Kolonic SF, Rehkämper M (2016) Molybdenum drawdown during Cretaceous Oceanic Anoxic Event 2. Earth Planet Sci Lett 440:81-91

Golden J, McMillan M, Downs RT, Hystad G, Goldstein I, Stein HJ, Zimmerman A, Sverjensky DA, Armstrong JT, Hazen RM (2013) Rhenium variations in molybdenite $\left(\mathrm{MoS}_{2}\right)$ : evidence for progressive subsurface oxidation. Earth Planet Sci Lett 366:1-5

Gordon GW, Lyons TW, Arnold GL, Roe J, Sageman BB, Anbar AD (2009) When do black shales tell molybdenum isotope tales? Geology 37:535-538

Goto KT, Shimoda G, Anbar AD, Gordon GW, Harigane Y, Senda R, Suzuki K (2015) Molybdenum isotopes in hydrothermal manganese crust from the Ryukyu arc system: Implications for the source of molybdenum. Mar Geol 369:91-99

Greber ND, Hofmann BA, Voegelin AR, Villa IM, Nägler TF (2011) Mo isotope composition in Mo-rich high- and low-T hydrothermal systems from the Swiss Alps. Geochim Cosmochim Acta 75:6600-6609

Greber, ND, Siebert C, Nägler TF, Pettke T (2012) $\delta^{98 / 95}$ Mo values and molybdenum concentration data for NIST SRM 610, 612 and 3134: Towards a common protocol for reporting Mo data. Geostand Geoanal Res 36:291-300

Greber ND, Pettke T, Nägler TF (2014) Magmatic-hydrothermal molybdenum isotope fractionation and its relevance to the igneous crustal signature. Lithos 190-191:104-110

Greber ND, Puchtel IS, Nägler TF, Mezger K (2015a) Komatiites constrain molybdenum isotope composition of the Earth's mantle. Earth Planet Sci Lett 421:129-138

Greber ND, Mäder U, Nägler TF (2015b) Experimental dissolution of molybdenum-sulphides at low oxygen concentrations: a first-order approximation of late Archean atmospheric conditions. Earth Space Science 2:173-180 
Hannah JL, Stein HJ, Wieser ME, de Laeter JR, Varner MD (2007) Molybdenum isotope variations in molybdenite: Vapor transport and Rayleigh fractionation of Mo. Geology 35:703706

Helz GR, Bura-Nakić E, Mikac N, Ciglenečki I (2011) New model for molybdenum behavior in euxinic waters. Chem Geol 284:323-332

Helz GR, Miller CV, Charnock JM, Mosselmans JFW, Pattrick RAD, Garner CD, Vaughan DJ, (1996) Mechanism of molybdenum removal from the sea and its concentration in black shales: EXAFS evidence. Geochim Cosmochim Acta 60:3631-3642

Helz GR, Vorlicek TP, Kahn MD (2004) Molybdenum Scavenging by Iron Monosulfide. Environ Sci Technol 38:4263-4268

Herrmann AD, Kendall B, Algeo TJ, Gordon GW, Wasylenki LE, Anbar AD (2012) Anomalous molybdenum isotope trends in Upper Pennsylvanian euxinic facies: Significance for use of $\delta^{98} \mathrm{Mo}$ as a global marine redox proxy. Chem Geol 324-325:87-98

Hille R (1996) The mononuclear molybdenum enzymes. Chem Rev 96:2757-2816

Hille R (2002) Molybdenum and tungsten in biology. Trends Biochem Sci 27:360-367

Hin RC, Burkhardt C, Schmidt MW, Bourdon B, Kleine T (2013) Experimental evidence for Mo isotope fractionation between metal and silicate liquids. Earth Planet Sci Lett 379:38-48

Holland HD (1984) The Chemical Evolution of the Atmosphere and Oceans. Princeton University Press, Princeton

International Molybdenum Association (2016). http://www.imoa.info/

Kashiwabara T, Takahashi Y, Tanimizu M, Usui A (2011) Molecular-scale mechanisms of distribution and isotopic fractionation of molybdenum between seawater and ferromanganese oxides. Geochim Cosmochim Acta 75:5762-5784

Kaufman AJ, Johnston DT, Farquhar J, Masterson AL, Lyons TW, Bates S, Anbar AD, Arnold GL, Garvin J, Buick R (2007) Late Archean biospheric oxygenation and atmospheric evolution. Science 317:1900-1903

Kendall B, Creaser RA, Gordon GW, Anbar AD (2009) Re-Os and Mo isotope systematics of black shales from the Middle Proterozoic Velkerri and Wollogorang Formations, McArthur Basin, northern Australia. Geochim Cosmochim Acta 73:2534-2558

Kendall B, Reinhard CT, Lyons TW, Kaufman AJ, Poulton SW, Anbar AD (2010) Pervasive oxygenation along late Archean ocean margins. Nature Geosci 3:647-652

Kendall B, Gordon GW, Poulton SW, Anbar AD (2011) Molybdenum isotope constraints on the extent of late Paleoproterozoic ocean euxinia. Earth Planet Sci Lett 307:450-460 
1899

1900

1901

1902

1903

1904

1905

1906

1907

1908

1909

1910

1911

1912

1913

1914

1915

1916

1917

1918

1919

1920

1921

1922

1923

1924

1925

1926

1927

1928

1929

1930

1931

1932

1933

1934

1935

1936

1937

1938

1939

1940

1941

1942

1943

1944

1945

Kendall B, Brennecka GA, Weyer S, Anbar AD (2013) Uranium isotope fractionation suggests oxidative uranium mobilization at $2.50 \mathrm{Ga}$. Chem Geol 362:105-114

Kendall B, Komiya T, Lyons TW, Bates SM, Gordon GW, Romaniello SJ, Jiang G, Creaser RA, Xiao S, McFadden K, Sawaki Y, Tahata M, Shu D, Han J, Li Y, Chu X, Anbar AD (2015a) Uranium and molybdenum isotope evidence for an episode of widespread ocean oxygenation during the late Ediacaran Period. Geochim Cosmochim Acta 156:173-193

Kendall B, Creaser RA, Reinhard CT, Lyons TW, Anbar AD (2015b) Transient episodes of mild environmental oxygenation and oxidative continental weathering during the late Archean. Science Adv 1:e1500777

Kowalski N, Dellwig O, Beck M, Gräwe U, Neubert N, Nägler TF, Badewien TH, Brumsack HJ, van Beusekom JEE, Böttcher ME (2013) Pelagic molybdenum concentration anomalies and the impact of sediment resuspension on the molybdenum budget in two tidal systems of the North Sea. Geochim Cosmochim Acta 119:198-211

Kurzweil F, Wille M, Schoenberg R, Taubald H, Van Kranendonk MJ (2015a) Continuously increasing $\delta^{98}$ Mo values in Neoarchean black shales and iron formations from the Hamersley Basin. Geochim Cosmochim Acta 164:523-542

Kurzweil F, Drost K, Pašava J, Wille M, Taubald H, Schoeckle D, Schoenberg R (2015b) Coupled sulfur, iron and molybdenum isotope data from black shales of the Teplá-Barrandian unit argue against deep ocean oxygenation during the Ediacaran. Geochim Cosmochim Acta $171: 121-142$

Lane S, Proemse BC, Tennant A, Wieser ME (2013) Concentration measurements and isotopic composition of airborne molybdenum collected in an urban environment. Anal Bioanal Chem 405:2957-2963

Lehmann B, Nägler TF, Holland HD, Wille M, Mao J, Pan J, Ma D, Dulski P (2007) Highly metalliferous carbonaceous shale and Early Cambrian seawater. Geology 35:403-406

Liermann LJ, Guynn RL, Anbar A, Brantley SL (2005) Production of a molybdophore during metal-targeted dissolution of silicates by soil bacteria. Chem Geol 220:285-302

Liermann LJ, Mathur R, Wasylenki LE, Nuester J, Anbar AD, Brantley SL (2011) Extent and isotopic composition of $\mathrm{Fe}$ and Mo release from two Pennsylvania shales in the presence of organic ligands and bacteria. Chem Geol 281:167-180

Liu Y (2008) Theoretical study on the mechanism of the removal of Mo from seawater in oxic environment. Geochim Cosmochim Acta 72:A564

Lillis PG, Selby D (2013) Evaluation of the rhenium-osmium geochronometer in the Phosphoria petroleum system, Bighorn Basin of Wyoming and Montana, USA. Geochim Cosmochim Acta $118: 312-330$ 
Lyons TW, Reinhard CT, Planavsky NJ (2014) The rise of oxygen in Earth's early ocean and

Mahdaoui F, Reisberg L, Michels R, Hauteville Y, Poirier Y, Girard J-P (2013) Effect of the progressive precipitation of petroleum asphaltenes on the Re-Os radioisotope system. Chem Geol 358:90-100

Malcolm S (1985) Early diagenesis of molybdenum in estuarine sediments. Mar Chem 16:213225

Malinovsky D, Rodushkin I, Baxter DC, Ingri J, Öhlander B (2005) Molybdenum isotope ratio measurements on geological samples by MC-ICPMS. Inter J Mass Spec 245:94-107

Malinovsky D, Hammarlund D, Ilyashuk B, Martinsson O, Gelting J (2007) Variations in the isotopic composition of molybdenum in freshwater lake systems. Chem Geol 236:181-198

Maréchal CN, Telouk P, Albarede F (1999) Precise analysis of copper and zinc isotopic compositions by plasma-source mass spectrometry. Chem Geol 156:251-273

Mathur R, Brantley S, Anbar A, Munizaga F, Maksaev V, Newburry R, Vervoort J, Hart G (2010) Variation of Mo isotopes from molybdenite in high-temperature hydrothermal ore deposits. Min Deposit 45:43-50

Mayer AJ, Wieser ME (2014) The absolute isotopic composition and atomic weight of molybdenum in SRM 3134 using an isotopic double spike. J Anal At Spectrom 29:85-94

McManus J, Nägler TF, Siebert C, Wheat CG, Hammond DE (2002) Oceanic molybdenum isotope fractionation: diagenesis and hydrothermal ridge-flank alteration. Geochem Geophys Geosyst 3:1078, 10.1029/2002GC000356

McManus J, Berelson WM, Severmann S, Poulson RL, Hammond DE, Klinkhammer GP, Holm C (2006) Molybdenum and uranium geochemistry in continental margin sediments: Paleoproxy potential. Geochim Cosmochim Acta 70:4643-4662

Mendel RR, Bittner F (2006). Cell biology of molybdenum. Biochim Biophys Acta 1763:621635

Migeon V, Bourdon B, Pili E, Fitoussi C (2015) An enhanced method for molybdenum separation and isotopic determination in uranium-rich materials and geological samples. J Anal At Spectrom 30:1988-1996

Miller CA, Peucker-Ehrenbrink B, Walker BD, Marcantonio F (2011) Re-assessing the surface cycling of molybdenum and rhenium. Geochim Cosmochim Acta 75:7146-7179

Miller RW, Eady RR (1988) Molybdenum and vanadium nitrogenases of Azotobacter chroococcum. Biochem J 256:429-432 
Morford JL, Emerson S (1999) The geochemistry of redox sensitive trace metals in sediments.

\section{Geochim Cosmochim Acta 63:1735-1750}

Morford JL, Emerson SR, Breckel EJ, Kim SH (2005) Diagenesis of oxyanions (V, U, Re, and Mo) in pore waters and sediments from a continental margin. Geochim Cosmochim Acta 69:5021-5032

Morford JL, Martin WR, Kalnejais LH, François R, Bothner M, Karle I-M (2007) Insights on geochemical cycling of U, Re and Mo from seasonal sampling in Boston Harbor, Massachusetts, USA. Geochim Cosmochim Acta 71:895-917

Morris AW (1975) Dissolved molybdenum and vanadium in the northeast Atlantic Ocean. Deep Sea Res 22:49-54

Murthy VR (1962) Isotopic anomalies of molybdenum in some iron meteorites. J Geophys Res 67:905-907

Murthy VR (1963) Elemental and isotopic abundances of molybdenum in some meteorites. Geochim Cosmochim Acta 27:1171-1178

Nagai Y, Yokoyama T (2016) Molybdenum isotopic analysis by negative thermal ionization mass spectrometry (N-TIMS): effects on oxygen isotopic composition. J Anal At Spectrom 31:948-960

Nägler TF, Siebert C, Lüschen H, Böttcher ME (2005) Sedimentary Mo isotope record across the Holocene fresh - brackish water transition of the Black Sea. Chem Geol 219:283-295

Nägler TF, Neubert N, Böttcher ME, Dellwig O, Schnetger B (2011) Molybdenum isotope fractionation in pelagic euxinia: evidence from the modern Black and Baltic Seas. Chem Geol 289:1-11

Nägler TF, Anbar AD, Archer C, Goldberg T, Gordon GW, Greber ND, Siebert C, Sohrin Y, Vance D (2014) Proposal for an international molybdenum isotope measurement standard and data representation. Geostand Geoanal Res 38:149-151

Nakagawa Y, Takano S, Firdaus ML, Norisuye K, Hirata T, Vance D, Sohrin Y (2012) The molybdenum isotopic composition of the modern ocean. Geochem J 46:131-141

Nameroff TJ, Balistrieri LS, Murray JW (2002). Suboxic trace metal geochemistry in the Eastern Tropical North Pacific. Geochim Cosmochim Acta 66:1139-1158

Neubert N, Nägler TF, Böttcher ME (2008) Sulfidity controls molybdenum isotope fractionation onto euxinic sediments: Evidence from the modern Black Sea. Geology 36:775-778

Neubert N, Heri AR, Voegelin AR, Nägler TF, Schlunegger F, Villa IM (2011) The molybdenum isotopic composition in river water: constraints from small catchments. Earth Planet Sci Lett 304:180-190 
Nissenbaum A, Swaine D (1976). Organic matter-metal interactions in recent sediments: the role of humic substances. Geochim Cosmochim Acta 40:809-816

Noordmann J, Weyer S, Montoya-Pino C, Dellwig O, Neubert N, Eckert S, Paetzel M, Böttcher ME (2015) Uranium and molybdenum isotope systematics in modern euxinic basins: case studies from the central Baltic Sea and the Kyllaren fjord (Norway). Chem Geol 396:182-195

Oyerinde OF, Weeks CL, Anbar AD, Spiro TG (2008) Solution structure of molybdic acid from Raman spectroscopy and DFT analysis. Inorg Chim Acta 361:1000-1007

Partin CA, Bekker A, Planavsky NJ, Lyons TW (2015) Euxinic conditions recorded in the ca. $1.93 \mathrm{Ga}$ Bravo Lake Formation, Nunavut (Canada): implications for oceanic redox evolution. Chem Geol 417:148-162

Pearce CR, Cohen AS, Coe AL, Burton KW (2008) Molybdenum isotope evidence for global ocean anoxia coupled with perturbations to the carbon cycle during the Early Jurassic. Geology $36: 231-234$

Pearce CR, Cohen AS, Parkinson IJ (2009) Quantitative Separation of Molybdenum and Rhenium from Geological Materials for Isotopic Determination by MC-ICP-MS. Geostand Geoanal Res 33:219-229

Pearce CR, Burton KW, Pogge von Strandmann PAE, James RH, Gíslason S (2010a) Molybdenum isotope behavior accompanying weathering and riverine transport in a basaltic terrain. Earth Planet Sci Lett 295:104-114

Pearce CR, Coe AL, Cohen AS (2010b) Seawater redox variations during the deposition of the Kimmeridge Clay Formation, United Kingdom (Upper Jurassic): evidence from molybdenum isotopes and trace metal ratios. Paleoceanogr PA4213

Pietruszka A, Walker RJ, Candela PA (2006) Determination of mass-dependent molybdenum isotopic variations by MC-ICP-MS: an evaluation of matrix effects. Chem Geol 225:121-136

Planavsky NJ, Asael D, Hofmann A, Reinhard CT, Lalonde SV, Knudsen A, Wang X, Ossa FO, Pecoits E, Smith AJB, Beukes NJ, Bekker A, Johnson TM, Konhauser KO, Lyons TW, Rouxel OJ (2014) Evidence for oxygenic photosynthesis half a billion years before the Great Oxidation Event. Nature Geosci 7:283-286

Poulson RL, Siebert C, McManus J, Berelson WM (2006) Authigenic molybdenum isotope signatures in marine sediments. Geology 34:617-620

Poulson Brucker RL, McManus J, Severmann S, Berelson WM (2009) Molybdenum behavior during early diagenesis: insights from Mo isotopes. Geochem Geophys Geosyst 10:Q06010

Poulton SW, Canfield DE (2005) Development of a sequential extraction procedure for iron: implications for iron partitioning in continentally derived particulates. Chem Geol 214:209-221 
Poulton SW, Canfield DE (2011) Ferruginous conditions: a dominant feature of the ocean through Earth's history. Elements 7:107-112

Poulton SW, Raiswell R (2002) The low-temperature geochemical cycle of iron: from continental fluxes to marine sediment deposition. Amer J Sci 302:774-805

Proemse BC, Grasby SE, Wieser ME, Mayer B, Beauchamp B (2013) Molybdenum isotopic evidence for oxic marine conditions during the latest Permian extinction. Geology 41:967-970

Rahaman W, Goswami V, Singh SK, Rai VK (2014) Molybdenum isotopes in two Indian estuaries: Mixing characteristics and input to oceans. Geochim Cosmochim Acta 141:407-422

Raiswell R, Canfield DE (1998) Sources of iron for pyrite formation in marine sediments. Amer J Sci 298:219-245

Raymond J, Siefert JL, Staples CR, Blankenship RE (2003) The Natural History of Nitrogen Fixation. Mole Biol Evol 21:541-554

Rees DC, Akif Tezcan F, Haynes CA, Walton MY, Andrade S, Einsle O, Howard JB (2005) Structural basis of biological nitrogen fixation. Phil Trans Series A Math Phys Eng Sci 363:971984; discussion 1035-1040

Reinhard CT, Raiswell R, Scott C, Anbar AD, Lyons TW (2009) A late Archean sulfidic sea stimulated by early oxidative weathering of the continents. Science 326:713:716

Reinhard CT, Planavsky NJ, Robbins LJ, Partin CA, Gill BC, Lalonde SV, Bekker A, Konhauser KO, Lyons TW (2013a) Proterozoic ocean redox and biogeochemical stasis. Proc Natl Acad Sci USA 110:5357-5362

Reinhard CT, Lalonde SV, Lyons TW (2013b) Oxidative sulfide dissolution on the early Earth. Chem Geol 362:44-55

Reitz A, Wille M, Nägler TF, de Lange GJ (2007) Atypical Mo isotope signatures in eastern Mediterranean sediments. Chem Geol 245:1-8

Rempel K, Migdisov A, Williams-Jones A (2006) The solubility and speciation of molybdenum in water vapour at elevated temperatures and pressures: implications for ore genesis. Geochim Cosmochim Acta 70:687-696

Rempel KU, Williams-Jones AE, Migdisov AA (2009) The partitioning of molybdenum (VI) between aqueous liquid and vapour at temperatures up to $370^{\circ} \mathrm{C}$. Geochim Cosmochim Acta 73:3381-3392

Romaniello SJ, Herrmann AD, Anbar AD (2016) Syndepositional diagenetic control of molybdenum isotope variations in carbonate sediments from the Bahamas. Chem Geol 438:8490 
Romao MJ, Knäblein J, Huber R, Moura JJG (1997) Structure and function of molybdopterin containing enzymes. Progress Biophys Molec Biol 68:121-144

Ryb U, Erel Y, Matthews A, Avni Y, Gordon GW, Anbar AD (2009) Large molybdenum isotope variations trace subsurface fluid migration along the Dead Sea transform. Geology 37:463-466

Sánchez-Baracaldo P, Ridgwell A, Raven JA (2014). A Neoproterozoic Transition in the Marine Nitrogen Cycle. Current Biol 24:652-657

Sarmiento JL, Gruber N (2006) Ocean Biogeochemical Dynamics. Princeton University Press, New Jersey, USA

Saxena RS, Jain MC, Mittal ML (1968). Electrometric investigations of an acid-thiomolybdate system and the formation of polyanions. Aus J Chem 21:91-96

Schoepp-Cothenet B, van Lis R, Philippot P, Magalon A, Russell MJ, Nitschke W (2012). The ineluctable requirement for the trans-iron elements molybdenum and/or tungsten in the origin of life. Scientific Reports 2:263

Scheiderich K, Zerkle AL, Helz GR, Farquhar J, Walker RJ (2010a) Molybdenum isotope, multiple sulfur isotope, and redox-sensitive element behavior in early Pleistocene Mediterranean sapropels. Chem Geol 279:134-144

Scheiderich K, Helz GR, Walker RJ (2010b) Century-long record of Mo isotopic composition in sediments of a seasonally anoxic estuary (Chesapeake Bay). Earth Planet Sci Lett 289:189-197

Scholz F, McManus J, Sommer S (2013) The manganese and iron shuttle in a modern euxinic basin and implications for molybdenum cycling at euxinic ocean margins. Chem Geol 355:56-68

Scott C, Lyons TW (2012) Contrasting molybdenum cycling and isotopic properties in euxinic versus non-euxinic sediments and sedimentary rocks: Refining the paleoproxies. Chem Geol 324-325:19-27

Scott C, Lyons TW, Bekker A, Shen Y, Poulton SW, Chu X, Anbar AD (2008) Tracing the stepwise oxygenation of the Proterozoic ocean. Nature 452:456-459

Segato A, Kendall B, Hanley J (2015) Further insights into Mo isotope variations in molybdenites from different ore deposits. Geol Soc Am Abstr Progr 47:243

Selby D, Creaser RA, Fowler MG (2007) Re-Os elemental and isotopic systematics in crude oils. Geochim Cosmochim Acta 71:378-386

Shafiei B, Shamanian G, Mathur R, Mirnejad H (2015) Mo isotope fractionation during hydrothermal evolution of porphyry systems. Min Deposit 50:281-291

2182

Shaw TJ, Gieskes JM, Jahnke RA (1990) Early diagenesis in differing depositional environments: The response of transition metals in pore water. Geochim Cosmochim Acta 54:1233-1246 
Shimmield G, Price N (1986). The behaviour of molybdenum and manganese during early sediment diagenesis offshore Baja California, Mexico. Mar Chem 19:261-280

Siebert C, Nägler TF, Kramers JD (2001) Determination of molybdenum isotope fractionation by double-spike multicollector inductively coupled plasma mass spectrometry. Geochem Geophys Geosyst 2:2000GC000124

Siebert C, Nägler TF, von Blanckenburg F, Kramers JD (2003) Molybdenum isotope records as a potential new proxy for paleoceanography. Earth Planet Sci Lett 211:159-171

Siebert C, Kramers JD, Meisel TH, Morel PH, Nägler TF (2005) PGE, Re-Os, and Mo isotope systematics in Archean and early Proterozoic sedimentary systems as proxies for redox conditions of the early Earth. Geochim Cosmochim Acta 69:1787-1801

Siebert C, McManus J, Bice A, Poulson R, Berelson WM (2006) Molybdenum isotope signatures in continental margin sediments. Earth Planet Sci Lett 241:723-733

Siebert C, Pett-Ridge JC, Opfergelt S, Guicharnaud RA, Halliday AN, Burton KW (2015) Molybdenum isotope fractionation in soils: Influence of redox conditions, organic matter, and atmospheric inputs. Geochim Cosmochim Acta 162:1-24

Skierszkan EK, Amini M, Weis D (2015) A practical guide for the design and implementation of the double-spike technique for precise determination of molybdenum isotope compositions of environmental samples. Anal Bioanal Chem 407:1925-1935

Smith RM, Martell AE (2004) NIST critically selected stability constants of metal complexes database. NIST Standard Reference Database 46, Version 8.0. National Institute of Standards and Technology.

Song S, Hu K, Wen H, Zhang Y, Li K, Fan H (2011) Molybdenum isotopic composition as a tracer for low-medium temperature hydrothermal ore-forming systems: A case study on the Dajiangping pyrite deposit, western Guangdong Province, China. Chinese Science Bull 56:22212228

Stein HJ, Markey RJ, Morgan JW, Hannah JL, Scherstén A (2001) The remarkable Re-Os chronometer in molybdenite: how and why it works. Terra Nova 13:479-486

Stiefel EI (1997) Chemical keys to molybdenum enzymes. J Chem Soc Dalton Trans 21:39153923

Stïeken EE, Buick R, Anbar AD (2015) Selenium isotopes support free $\mathrm{O}_{2}$ in the latest Archean. Geology 43:259-262

Sundby B, Martinez P, Gobeil C (2004). Comparative geochemistry of cadmium, rhenium, uranium, and molybdenum in continental margin sediments. Geochim Cosmochim Acta 68:2485-2493 
Szilagyi M (1967) Sorption of molybdenum by humus preparations. Geochem Internat 4:11651167

Tossell JA (2005) Calculating the partitioning of the isotopes of Mo between oxidic and sulfidic species in aqueous solution. Geochim Cosmochim Acta 69:2981-2993

Tribovillard N, Algeo TJ, Lyons T, Riboulleau A (2006) Trace metals as paleoredox and paleoproductivity proxies: an update. Chem Geol 232:12-32

Tribovillard N, Algeo TJ, Baudin F, Riboulleau A (2012) Analysis of marine environmental conditions based on molybdenum-uranium covariation-Applications to Mesozoic paleoceanography. Chem Geol 324-325:46-58

Tuit C (2003) The marine biogeochemistry of molybdenum, Massachussets Institute of Technology and Woods Hole Oceanographic Institution. PhD thesis

Ulrich T, Mavrogenes J (2008) An experimental study of the solubility of molybdenum in $\mathrm{H} 2 \mathrm{O}$ and $\mathrm{KCl}-\mathrm{H}_{2} \mathrm{O}$ solutions from $500^{\circ} \mathrm{C}$ to $800^{\circ} \mathrm{C}$, and 150 to $300 \mathrm{MPa}$. Geochim Cosmochim Acta 72:2316-2330

Urey HC (1947) The thermodynamic properties of isotopic substances. J Chem Soc 562-581

Ventura GT, Gall L, Siebert C, Prytulak J, Szatmari P, Hürlimann M, Halliday AN (2015) The stable isotope composition of vanadium, nickel, and molybdenum in crude oils. Appl Geochem 59:104-117

Voegelin AR, Nägler TF, Samankassou E, Villa IM (2009) Molybdenum isotopic composition of modern and Carboniferous carbonates. Chem Geol 265:488-498

Voegelin AR, Nägler TF, Beukes NJ, Lacassie JP (2010) Molybdenum isotopes in late Archean carbonate rocks: Implications for early Earth oxygenation. Precambr Res 182:70-82

Voegelin AR, Nägler TF, Pettke T, Neubert N, Steinmann M, Pourret O, Villa IM (2012) The impact of igneous bedrock weathering on the Mo isotopic composition of stream waters: Natural samples and laboratory experiments. Geochim Cosmochim Acta 86:150-165

Voegelin AR, Pettke T, Greber ND. von Niederhäusern B, Nägler TF (2014) Magma differentiation fractionates Mo isotope ratios: evidence from the Kos Plateau Tuff (Aegean Arc). Lithos 190:440-448

Vorlicek TP, Kahn MD, Kasuya Y, Helz GR (2004) Capture of molybdenum in pyrite-forming sediments: role of ligand-induced reduction by polysulfides. Geochim Cosmochim Acta 68:547556

Wang D, Aller RC, Sañudo-Wilhelmy SA (2011) Redox speciation and early diagenetic behavior of dissolved molybdenum in sulfidic muds. Marine Chem 125:101-107 

isotopes in molybdenite from porphyry and vein Mo deposits in the Gangdese metallogenic belt,

Wang Z, Ma J, Li J, Wei G, Chen X, Deng W, Xie L, Lu W, Zou L (2015) Chemical weathering controls on variations in the molybdenum isotopic composition of river water: Evidence from large rivers in China. Chem Geol 410:201-212

Wasylenki LE, Anbar AD, Liermann LJ, Mathur R, Gordon GW, Brantley SL (2007) Isotope fractionation during microbial metal uptake measured by MC-ICP-MS. J Anal At Spectrom 22:905-910

Wasylenki LE, Rolfe BA, Weeks CL, Spiro TG, Anbar AD (2008) Experimental investigation of the effects of temperature and ionic strength on Mo isotope fractionation during adsorption to manganese oxides. Geochim Cosmochim Acta 72:5997-6005

Wasylenki LE, Weeks CL, Bargar JR, Spiro TG, Hein JR, Anbar AD (2011) The molecular mechanism of Mo isotope fractionation during adsorption to birnessite. Geochim Cosmochim Acta 75:5019-5031

Wen H, Carignan J, Zhang Y, Fan H, Cloquet C, Liu S (2011) Molybdenum isotopic records across the Precambrian-Cambrian boundary. Geology 39:775-778

Wen H, Fan H, Zhang Y, Cloquet C, Carignan J (2015) Reconstruction of early Cambrian ocean chemistry from Mo isotopes. Geochim Cosmochim Acta 164:1-16

Westermann S, Vance D, Cameron V, Archer C, Robinson SA (2014) Heterogeneous oxygenation states in the Atlantic and Tethys oceans during Oceanic Anoxic Event 2. Earth Planet Sci Lett 404:178-189

Wetherill GW (1964) Isotopic composition and concentration of molybdenum in iron meteorites. J Geophys Res 69:4403-4408

Wheat CG, Mottl MJ, Rudnicki M (2002) Trace element and REE composition of a lowtemperature ridge-flank hydrothermal spring. Geochim Cosmochim Acta 66:3693-3705

White WM (2015) Isotope Geochemistry. Wiley-Blackwell.

Wichard T, Mishra B, Myneni SCB, Bellenger J-P, Kraepiel AML (2009). Storage and bioavailability of molybdenum in soils increased by organic matter complexation. Nature Geosci 2:625-629

Wieser ME, De Laeter JR, Varner MD (2007) Isotope fractionation studies of molybdenum. Internat J Mass Spec 265:40-48 
Willbold M, Hibbert K, Lai YJ, Freymuth H, Hin RC, Coath C, Vils F, Elliott T (2016) Highprecision mass-dependent molybdenum isotope variations in magmatic rocks determined by double-spike MC-ICP-MS. Geostand Geoanal Res, Online Version (Early View)

Wille M, Kramers JD, Nägler TF, Beukes NJ, Schröder S, Meisel TH, Lacassie JP, Voegelin AR (2007) Evidence for a gradual rise of oxygen between 2.6 and 2.5 Ga from Mo isotopes and RePGE signatures in shales. Geochim Cosmochim Acta 71:2417-2435

Wille M, Nägler TF, Lehmann B, Schröder S, Kramers JD (2008) Hydrogen sulphide release to surface waters at the Precambrian/Cambrian boundary. Nature 453:767-769

Wille M, Nebel O, Van Kranendonk MJ, Schoenberg R, Kleinhanns IC, Ellwood MJ (2013) Mo$\mathrm{Cr}$ isotope evidence for a reducing Archean atmosphere in 3.46-2.76 Ga black shales from the Pilbara, Western Australia. Chem Geol 340:68-76

Xu L, Lehmann B, Mao J, Nägler TF, Neubert N, Böttcher ME, Escher P (2012) Mo isotope and trace element patterns of Lower Cambrian black shales in South China: Multi-proxy constraints on the paleoenvironment. Chem Geol 318-319:45-59

Yang J, Siebert C, Barling J, Savage P, Liang Y-H, Halliday AN (2015) Absence of molybdenum isotope fractionation during magmatic differentiation at Hekla volcano, Iceland. Geochim Cosmochim Acta 162:126-136

Yin Q, Jacobsen SB, Yamashita K (2002) Diverse supernova sources of pre-solar material inferred from molybdenum isotopes in meteorites. Nature 415:881-883

Zerkle AL, Scheiderich K, Maresca JA, Liermann LJ, Brantley SL (2011) Molybdenum isotope fractionation by cyanobacterial assimilation during nitrate utilization and $\mathrm{N}_{2}$ fixation. Geobiol 9:94-106

Zerkle AL, House CH, Cox RP, Canfield DE (2006). Metal limitation of cyanobacterial $\mathrm{N}_{2}$ fixation and implications for the Precambrian nitrogen cycle. Geobiol 4:285-297

Zerkle AL, Claire MW, Domagal-Goldman SD, Farquhar J, Poulton SW (2012) A bistable organic-rich atmosphere on the Neoarchaean Earth. Nature Geosci 5:359-363

Zhang L, Audétat A, Dolejš D (2012) Solubility of molybdenite $\left(\mathrm{MoS}_{2}\right)$ in aqueous fluids at 600$800^{\circ} \mathrm{C}, 200 \mathrm{MPa}$ : A synthetic fluid inclusion study. Geochim Cosmochim Acta 77:175-185

Zheng Y, Anderson RF, Geen AV, Kuwabara K. (2000) Authigenic molybdenum formation in marine sediments: A link to pore water sulfide in the Santa Barbara Basin. Geochim Cosmochim Acta 64:4165-4178

Zhou L, Wignall PB, Su J, Feng Q, Xie S, Zhao L, Huang J (2012) U/Mo ratios and $\delta^{98 / 95}$ Mo as local and global redox proxies during mass extinction events. Chem Geol 324-325:99-107 

productivity and redox conditions during the Late Ordovician Hirnantian glaciation. Palaeogeogr

\section{Figure Captions}

2373

2374

2375

2376

2377

2378

2379

2380

2381

2382

2383

2384

2385

2386

2387

2388

2389

2390

2391

2392

2393

2394

2395

2396

2397

2398

2399

2400

2401

2402

2403

2404

2405

2406

2407

Figure 1. Abundances of the seven stable isotopes of Mo, based on Mayer and Wieser (2014).

Figure 2. Eh-pH diagram showing dissolved $\mathrm{Mo}$ speciation in the system $\mathrm{Mo}-\mathrm{H}_{2} \mathrm{O}-\mathrm{H}_{2} \mathrm{~S}$, assuming that $\Sigma \mathrm{Mo}=10^{-6} \mathrm{M}$ and $\Sigma \mathrm{S}=10^{-4} \mathrm{M}$. Molybdate protonation constants from $\mathrm{H}_{2} \mathrm{MoO}_{4}$ and $\mathrm{HMoO}_{4}{ }^{-}$are from Smith and Martell (2004). The Mo speciation below the $\mathrm{SO}_{4}{ }^{2-}-\mathrm{H}_{2} \mathrm{~S}$ transition is not well known. The boundary between $\mathrm{MoO}_{4}{ }^{2-}$ and $\mathrm{MoS}_{4}{ }^{2-}$ was calculated using equilibrium constants from Erickson and Helz (2000). Other metastable thiomolybdates are not indicated. a) Classical diagram that does not include $\mathrm{MoO}_{2}{ }^{+}$, modified from Anbar (2004). b) Diagram that includes $\mathrm{MoO}_{2}{ }^{+}$, recognizing the possible importance of $\mathrm{Mo}(\mathrm{V})$ species (Wang et al., 2011).

Figure 3. Standard reduction potentials (at $\mathrm{pH}=7$ relative to the hydrogen electrode) for the different oxidation states of Mo, Fe and Mn. The slope between any two points is equal to the redox potential. In contrast to most metals, Mo has multiple oxidation states that span a small range of potentials. Modified from Frausto da Silva and Williams (2001).

Figure 4. Mo isotope fractionation between Mo-bearing solutions and synthetic Mn oxides ($\mathrm{MnO}_{2}$ ), measured over 2-96 hours at $\mathrm{pH}=6.5-8.5$. Residual Mo in solution ( $\mathbf{m}$ ) was measured for all experiments. Mo adsorbed to oxide particle surfaces $(\bullet)$ was either measured or inferred from mass balance. Dissolved Mo was systematically heavier than adsorbed Mo with a fractionation factor of $1.0027 \pm 0.0008$. The data are not consistent with an irreversible Rayleigh-type distillation process, but instead point to closed system equilibrium in which Mo isotopes exchange continuously between $\mathrm{Mn}$ oxide surfaces and solution (i.e., a reversible process). Modified from Barling and Anbar (2004).

Figure 5. Molybdenum isotope composition of meteorites, the upper mantle (represented by komatiites), various crustal reservoirs, marine sediments, crude oil, and seawater. See text for sources of data.

Figure 6. A schematic depiction of the Mo elemental budget in the modern oceans. Rough estimates of the Mo fluxes in $10^{8} \mathrm{~mol} / \mathrm{yr}$ are shown (see text for discussion). Sources of data: rivers: Miller et al. (2011); low-T hydrothermal fluids: Wheat et al. (2002); oxic, sulfidic at depth (i.e., dissolved sulfide is confined to sediment pore waters), and euxinic (i.e., dissolved sulfide is in the overlying water column) sediments: Scott et al. (2008) and Reinhard et al. (2013a) (scaled in proportion to the combined river and low-T hydrothermal fluid fluxes). 
Figure 7. Molybdenum isotope composition of the sources and sinks of Mo in the modern oceans. The Mo isotope system is unusual compared with other isotope systems in that seawater is the isotopically heaviest reservoir, a consequence of the preferential removal of isotopically light Mo to sediments in all redox environments except strongly euxinic settings. See text for sources of data.

Figure 8. Mo concentration and isotopic composition in sediments at various water depths in the modern Black Sea, illustrating the change in geochemical behavior across the $\mathrm{O}_{2}-\mathrm{H}_{2} \mathrm{~S}$ chemocline (note the break in scale). a) Mo concentrations. b) Mo isotope compositions. The two black and white dots denote samples whose Mo content is significantly influenced by detrital material. c) Dissolved hydrogen sulfide concentrations. At $\left[\mathrm{H}_{2} \mathrm{~S}\right]_{\text {aq }}$ concentrations greater than 11 $\mu \mathrm{M}$ (below $\sim 400 \mathrm{~m}$ water depth), the $\delta^{98} \mathrm{Mo}$ of the sediments becomes similar to the open ocean seawater $\delta^{98}$ Mo. Modified from Neubert et al. (2008).

Figure 9. Molybdenum cycling in different redox settings. The relative concentrations of Mo and $\mathrm{Mn}$ increase from left to right in each profile and the dissolved Mo species in the bottom waters are shown along the top of each profile. a) Non-euxinic sediments with a manganous zone and no sulfidic zone. b) Non-euxinic sediments with both manganous and sulfidic zones. c) Noneuxinic sediments with a sulfidic zone and no manganous zone. d) Euxinic sediments where thiomolybdates are present in bottom waters. Examples of each category are from Baja California (Shimmield and Price, 1986), Loch Etive, Scotland (Malcolm, 1985), Santa Barbara, California basin (Poulson-Brucker et al., 2009), Black Sea (Neubert et al., 2008), and the Cariaco Basin (Dean et al., 1999). The Mo concentration of average crustal rocks is shown. In noneuxinic environments, Mo concentrations in sediments are typically $<25$ ppm (the crustal concentration and $25 \mathrm{ppm}$ are shown as grey dashed lines). The heavy dashed line illustrates the higher Mo concentrations in Cariaco Basin euxinic sediments compared with the more restricted Black Sea. Modified from Scott and Lyons (2012).

Figure 10. Relationship between the relative sizes of the oxic, sulfidic at depth, and euxinic sinks on the seawater Mo isotope composition, as derived from mass balance modelling. The black dot represents the modern Mo isotope budget. The shaded region encompassed by the arrow represents the overall direction that seawater $\delta^{98}$ Mo would take in response to increased deep ocean oxygenation. The hatched area represents mass balance solutions that are unrealistic because it would require that both the oxic and euxinic sinks expand at the expense of the "sulfidic at depth" sink. F = flux; Ox = oxic sink; SAD = sulfidic at depth sink; EUX = euxinic sink. Modified from Chen et al. (2015). 
Figure 11. Mo isotope compositions of late Archean sedimentary rocks from the Hamersley Basin (Western Australia), and Griqualand West Basin (South Africa), modified from Kurzweil et al. (2015). Sedimentary rocks containing higher $\delta^{98}$ Mo than the igneous baseline point to fractionation of Mo isotopes in surficial environments, consistent with mild environmental oxygenation. M.M. = Marrra Mamba Formation; Lo $=$ Lokammona Formation; Bo $=$ Boomplaas Formation. Sources of data: Wille et al. (2007), Duan et al. (2010), Voegelin et al. (2010), Kurzweil et al. (2015).

Figure 12. a) Temporal record of Mo isotope compositions in euxinic organic-rich mudrocks. For each time interval, the squares represent the highest $\delta^{98} \mathrm{Mo}$, whereas circles represent other data. b) Comparison of the highest $\delta^{98} \mathrm{Mo}$ and associated average Mo/TOC ratios of the time intervals. High $\delta^{98} \mathrm{Mo}$ and Mo/TOC indicates widespread ocean oxygenation whereas low $\delta^{98} \mathrm{Mo}$ and Mo/TOC indicates significant ocean anoxia. Exceptions to this trend (upper left circle) are the modern, highly restricted Black Sea and Jurassic oceanic anoxic events (both causing low $\mathrm{Mo} / \mathrm{TOC})$. The Jurassic oceanic anoxic events were followed by a return to widespread oxygenation and high seawater $\delta^{98} \mathrm{Mo}$. See text for sources of data. Modified from Kendall et al. (2015a).

Figure 13. Range and mean of the Mo isotope compositions in molybdenite from different types of ore deposit. The strong overlap in $\delta^{98}$ Mo among different ore deposit types indicates that Mo isotopes cannot be used to fingerprint the type of mineralization. IOGC $=$ iron oxide copper-gold deposits. Modified from Breillat et al. (2016).

Figure 14. Molybdenum isotope compositions of molybdenite from different stages of mineralization in the Kerman porphyry copper deposits, Iran. The black bars represent the average $\delta^{98}$ Mo for each mineralization stage. In this deposit, the molybdenite data suggest an overall evolution of the mineralizing fluid to lower $\delta^{98}$ Mo over time. Modified from Shafiei et al. (2015).

Figure 15. Molybdenum isotope compositions of molybdenite from different stages of mineralization in the Questa porphyry deposit, New Mexico, U.S.A. Black bars represent the median Mo isotope composition of each mineralization stage. This deposit provides an example of possible fluid evolution to higher $\delta^{98}$ Mo over time. MHBX = magmatic-hydrothermal breccia; STW $=$ stockwork veins. Modified from Greber et al. (2014). 


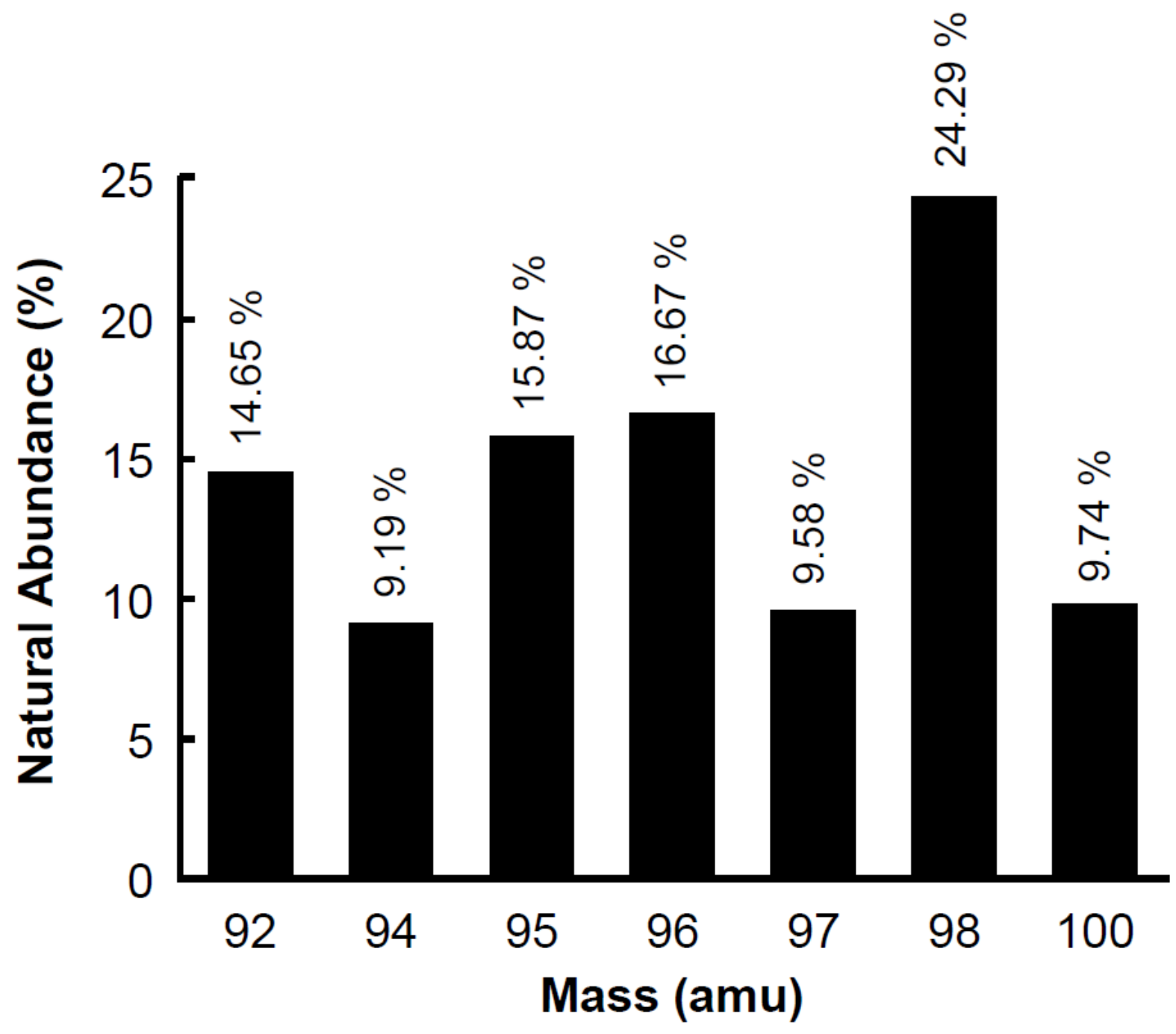


Figure 2

2504
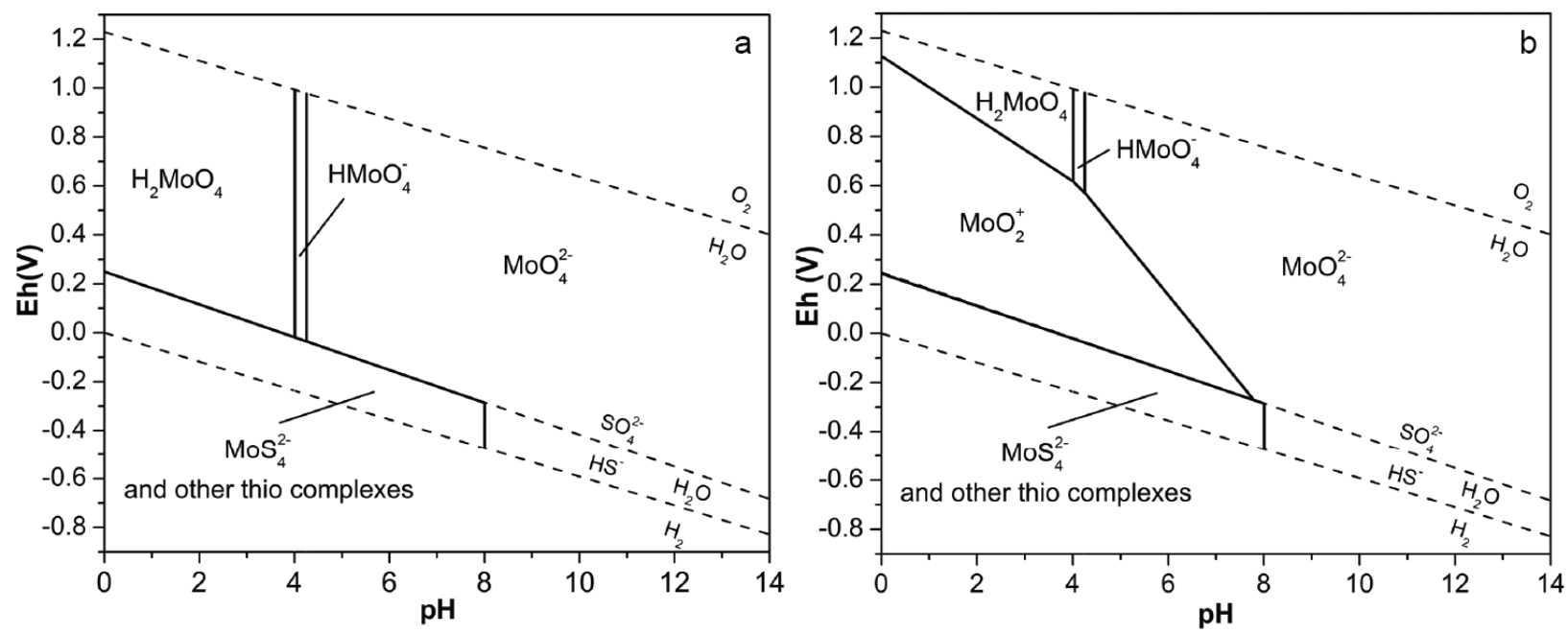

2505

2506

2507

2508

2509

2510

2511

2512

2513

2514

2515

2516

2517

2518

2519

2520

2521

2522

2523

2524

2525

2526

2527

2528

2529

2530

2531 


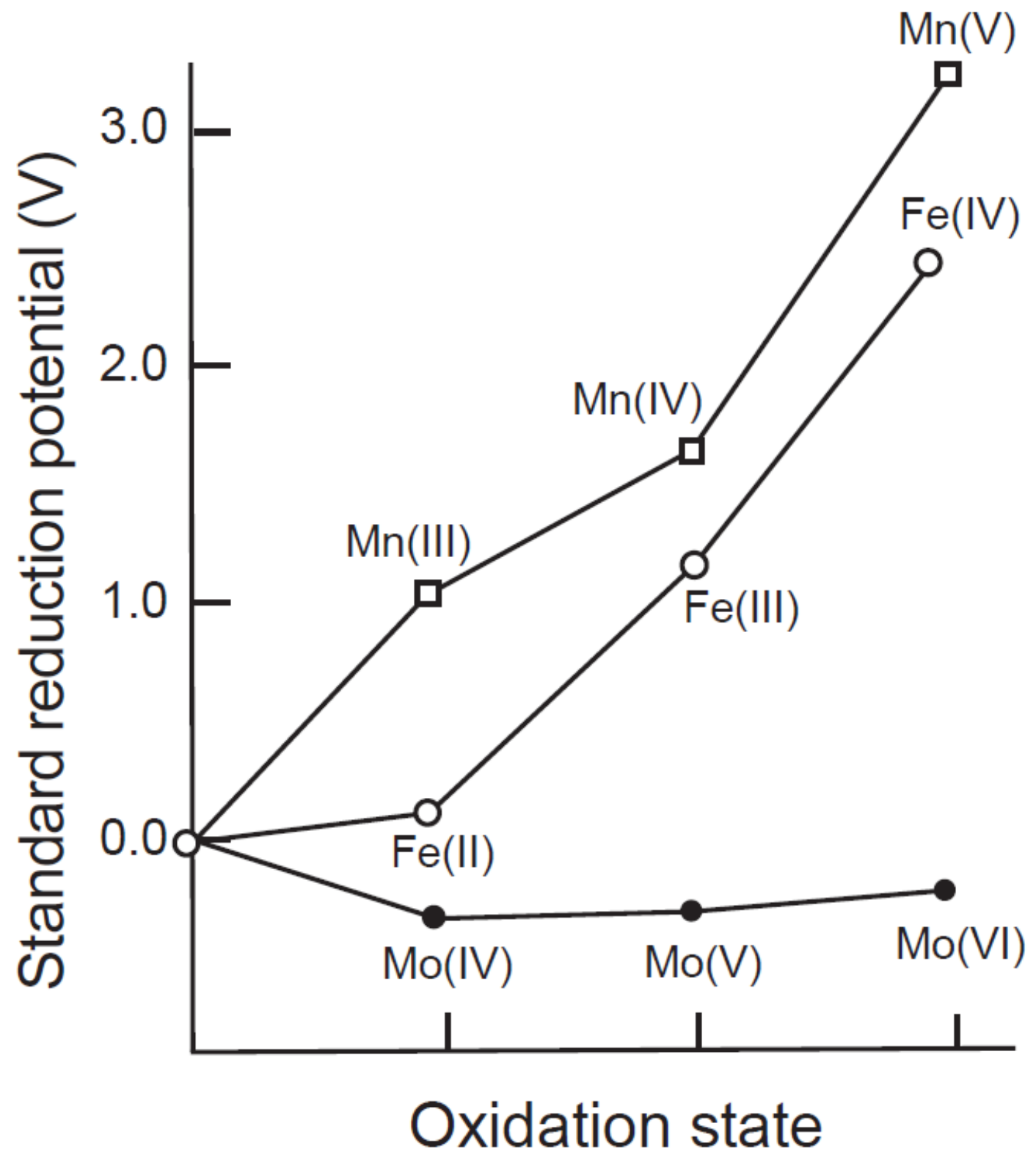

2534

2535

2536

2537

2538

2539

2540

2541

2542 


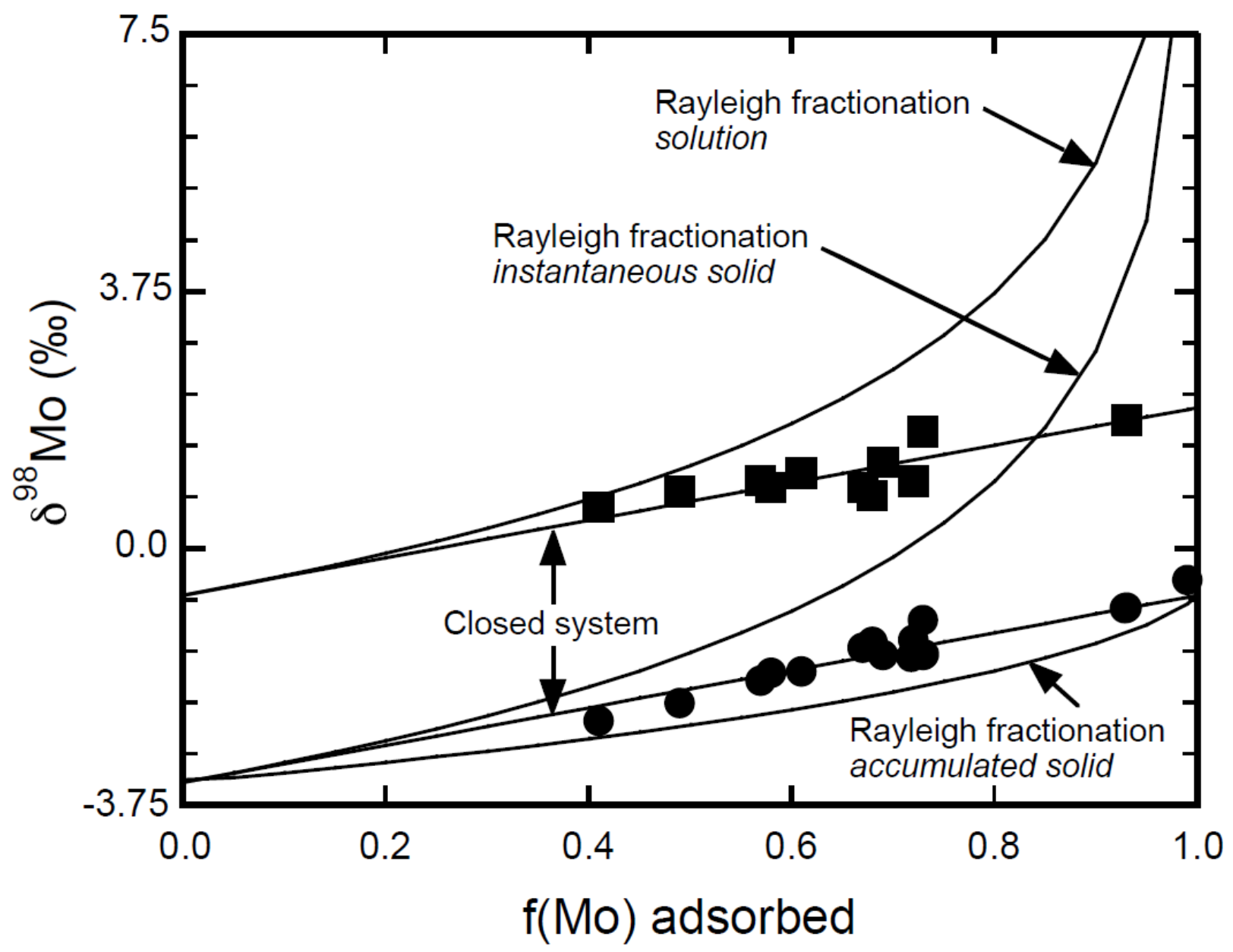

2545

2546

2547

2548

2549

2550

2551

2552

2553

2554

2555

2556

2557

2558

2559

2560 
$2561 \quad$ Figure 5

2562

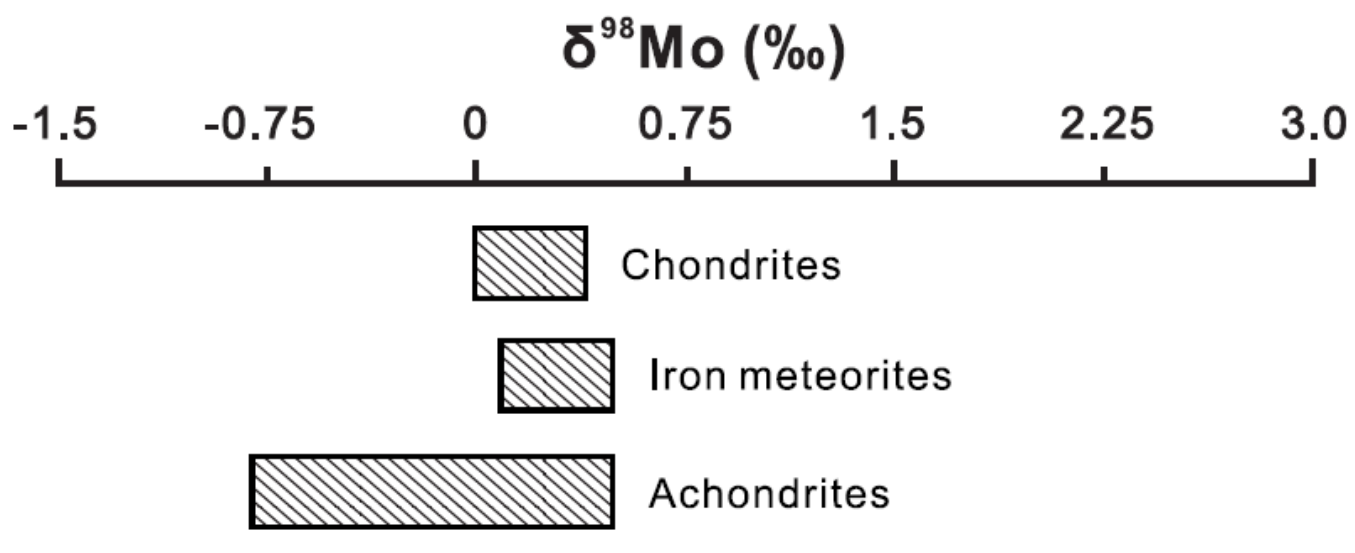

Komatiites

Crustal Igneous rocks

(felsic to mafic)

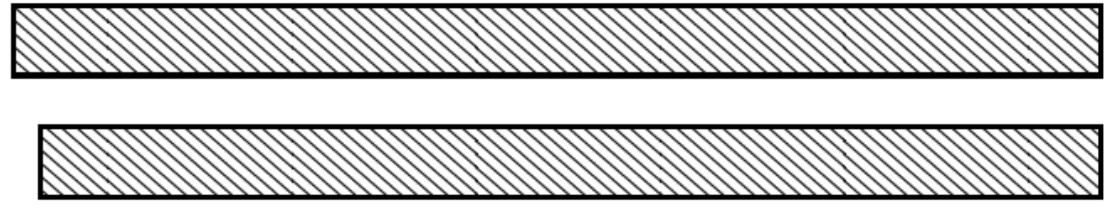

Molybdenites

Euxinic organic-rich mudrocks

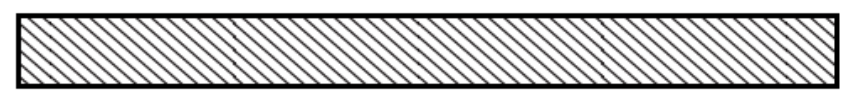

Marine Sediments

WWV Crude oil 
Rivers

Hydrothermal
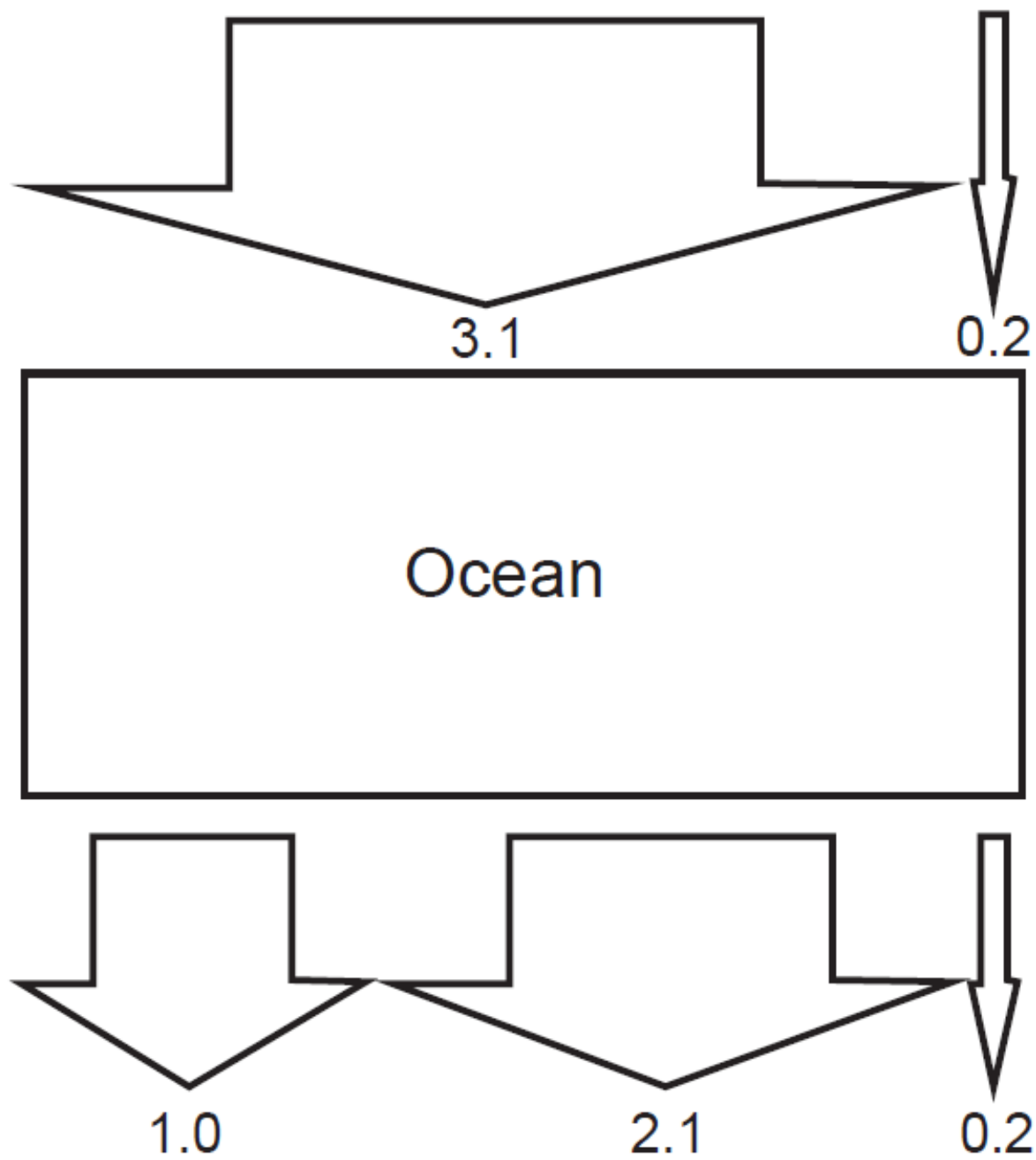


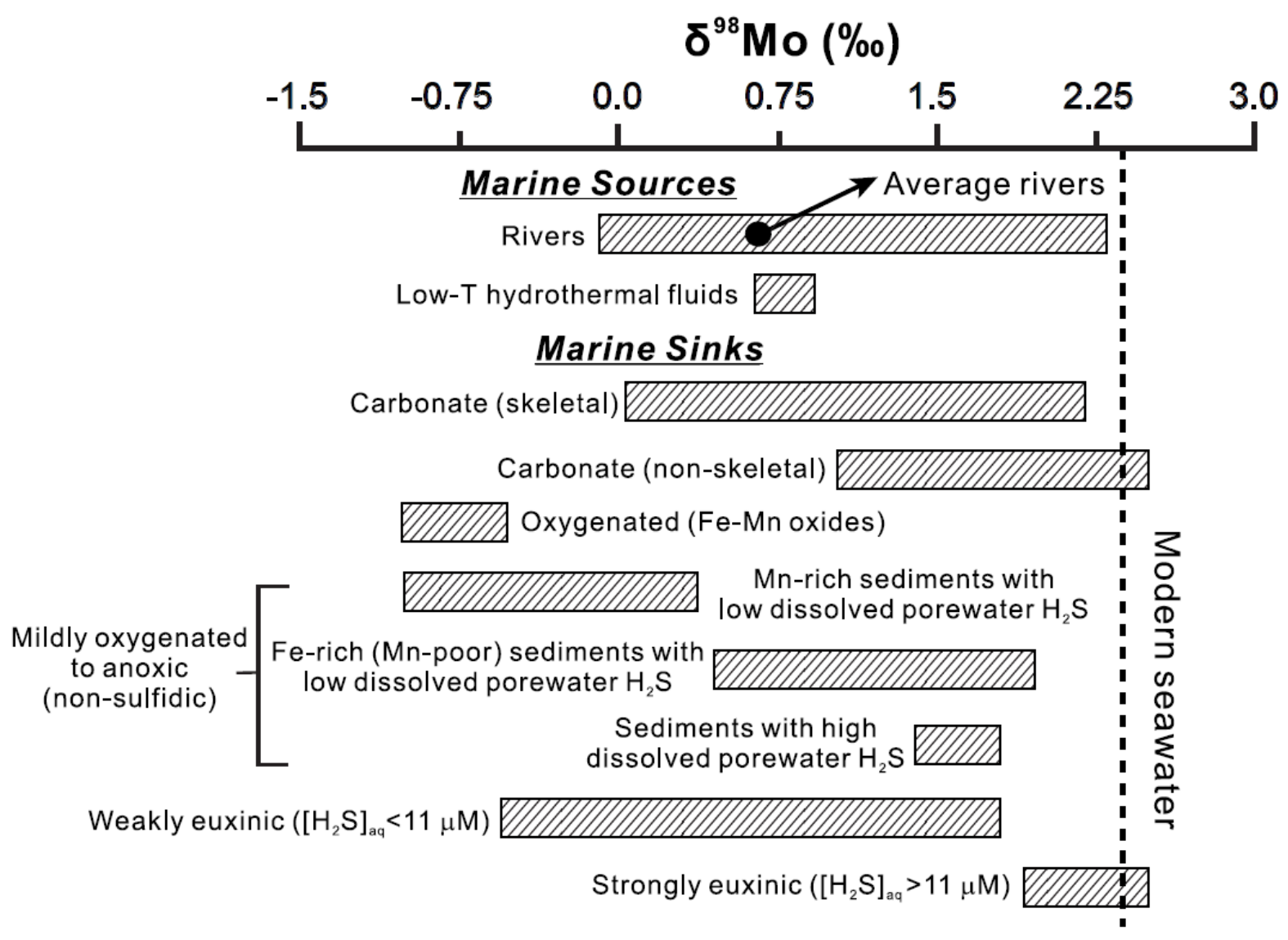

2590

2591

2592

2593

2594

2595

2596

2597

2598

2599

2600

2601

2602

2603

2604

2605

2606 


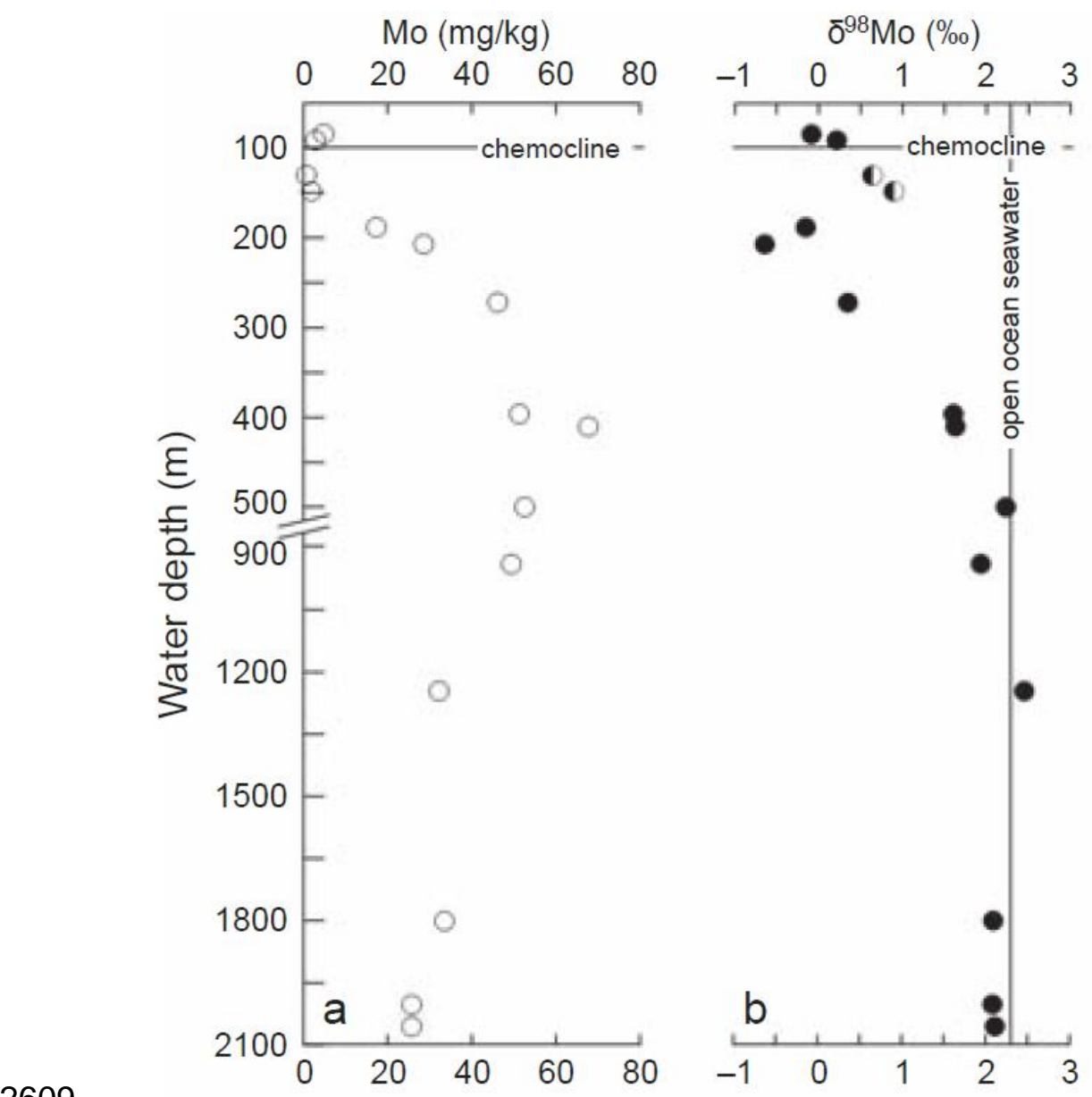

$\diamond$ Log $\mathrm{H}_{2} \mathrm{~S}_{\text {aq }}\left(\mu \mathrm{mol} \mathrm{I} \mathrm{I}^{-1}\right)$
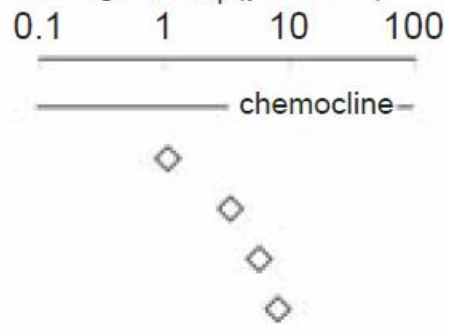

2610

2611

2612

2613

2614

2615

2616

2617

2618

2619

2620

2621

2622

2623

2624

2625 
Figure 9

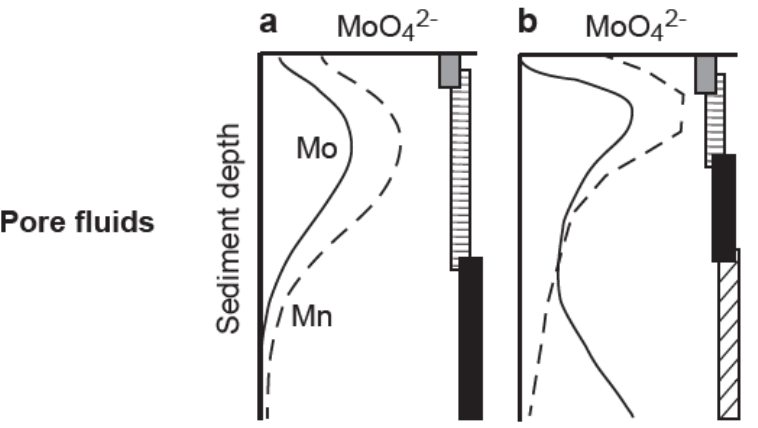

b $\mathrm{MoO}_{4}{ }^{2-}$

c $\mathrm{MoO}_{4}{ }^{2-}$

d $\mathrm{MoO}_{4-\mathrm{x}} \mathrm{S}^{2-}$
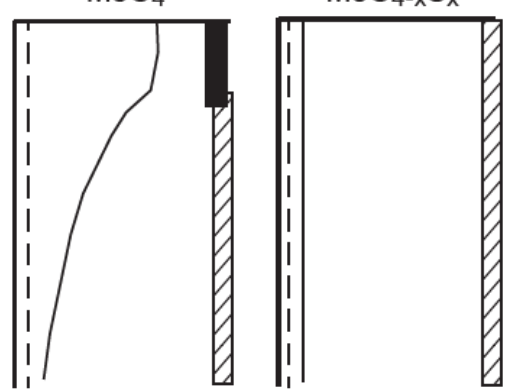

Bottom water conditions

$\mathrm{O}_{2}$ » $10 \mu \mathrm{M}$

$\mathrm{O}_{2}>10 \mu \mathrm{M}$

$\mathrm{O}_{2}<10 \mu \mathrm{M}$

Oxic zone

conditions

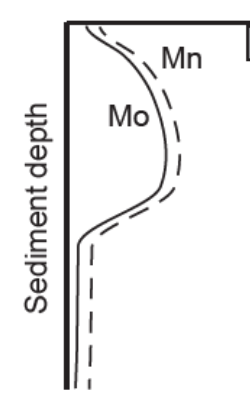

Examples

Baja California

(>3 km depth)
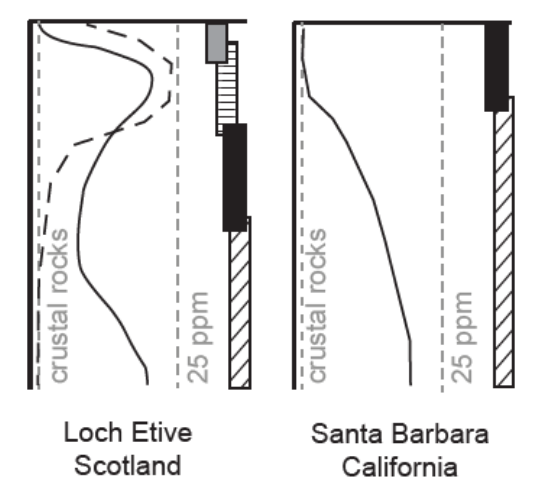

$\mathrm{H}_{2} \mathrm{~S}>11 \mu \mathrm{M}$

国 Mn-oxide zone

Fe-oxide zone

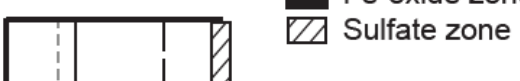

Sediments

2629

2630

2631

2632

2633

2634

2635

2636

2637

2638

2639

2640

2641

2642

2643

2644

2645

2646

2647

2648 
2649

2650

Figure 10

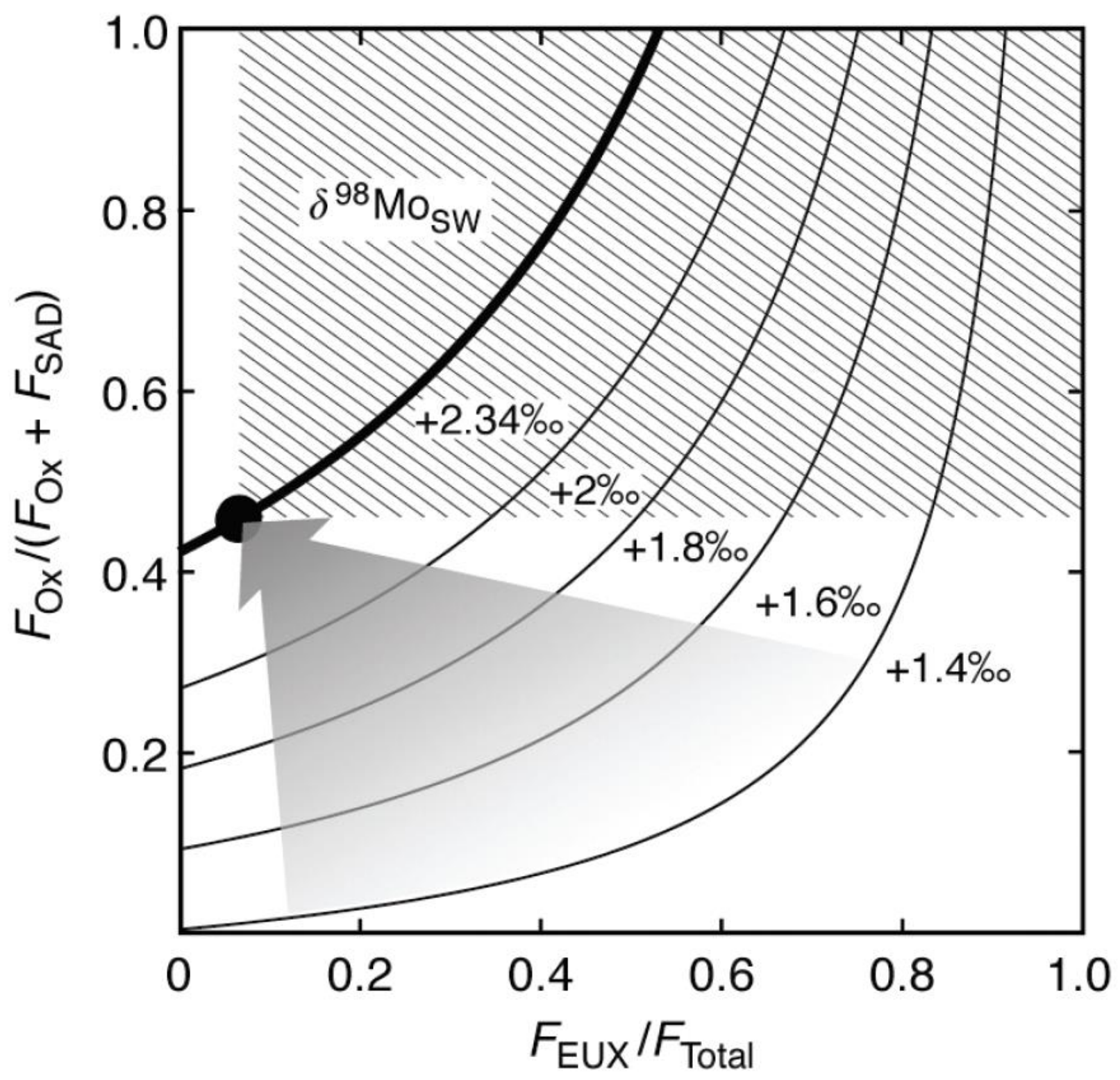

2651

2652

2653

2654

2655

2656

2657

2658

2659

2660

2661 
Organic-rich Mudrock

$\square$ Iron Formation

$\triangle$ Carbonate

2665

2666

2667

2668

2669

2670

2671

2672

2673

2674

2675

2676

2677

2678

2679

2680

2681

2682 


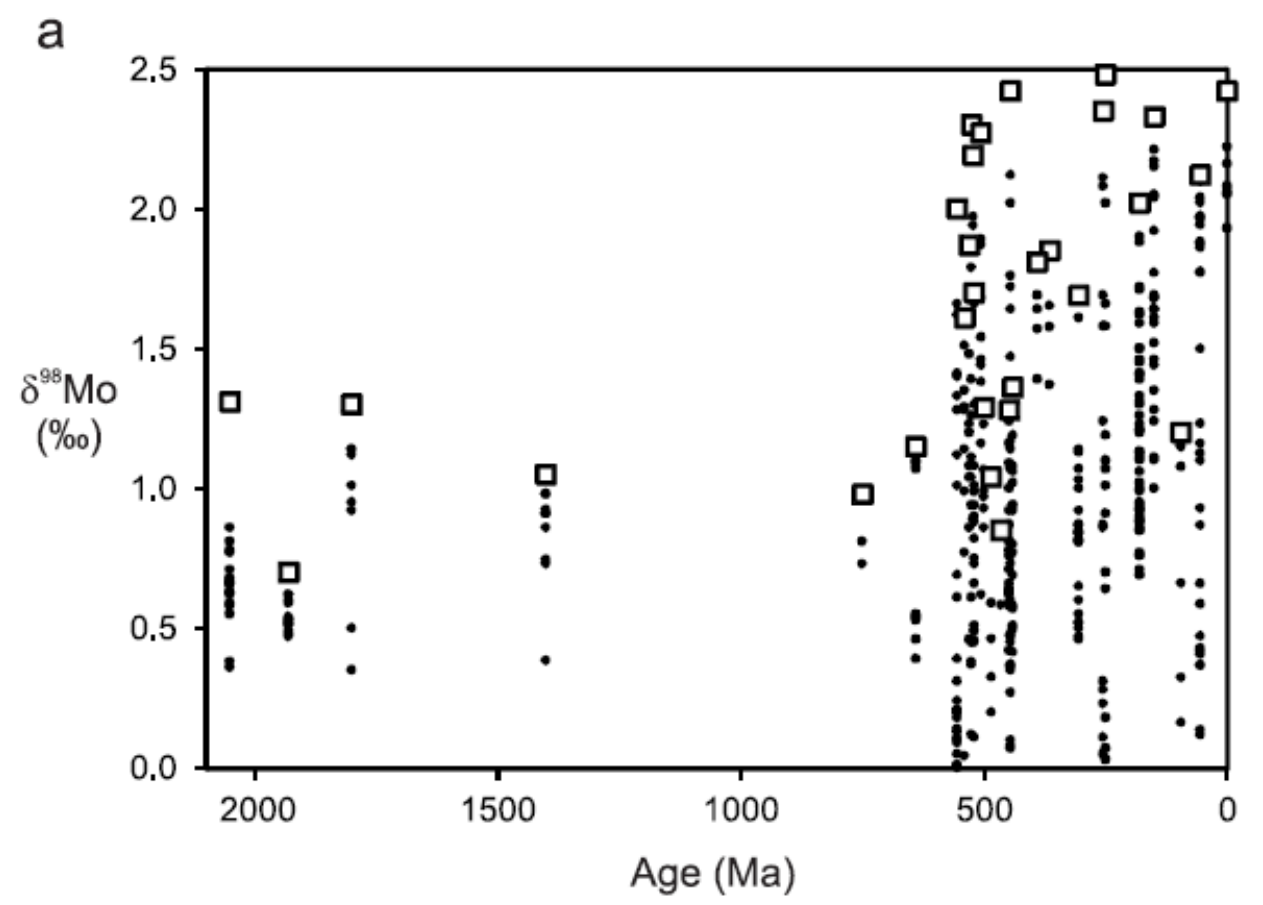

b

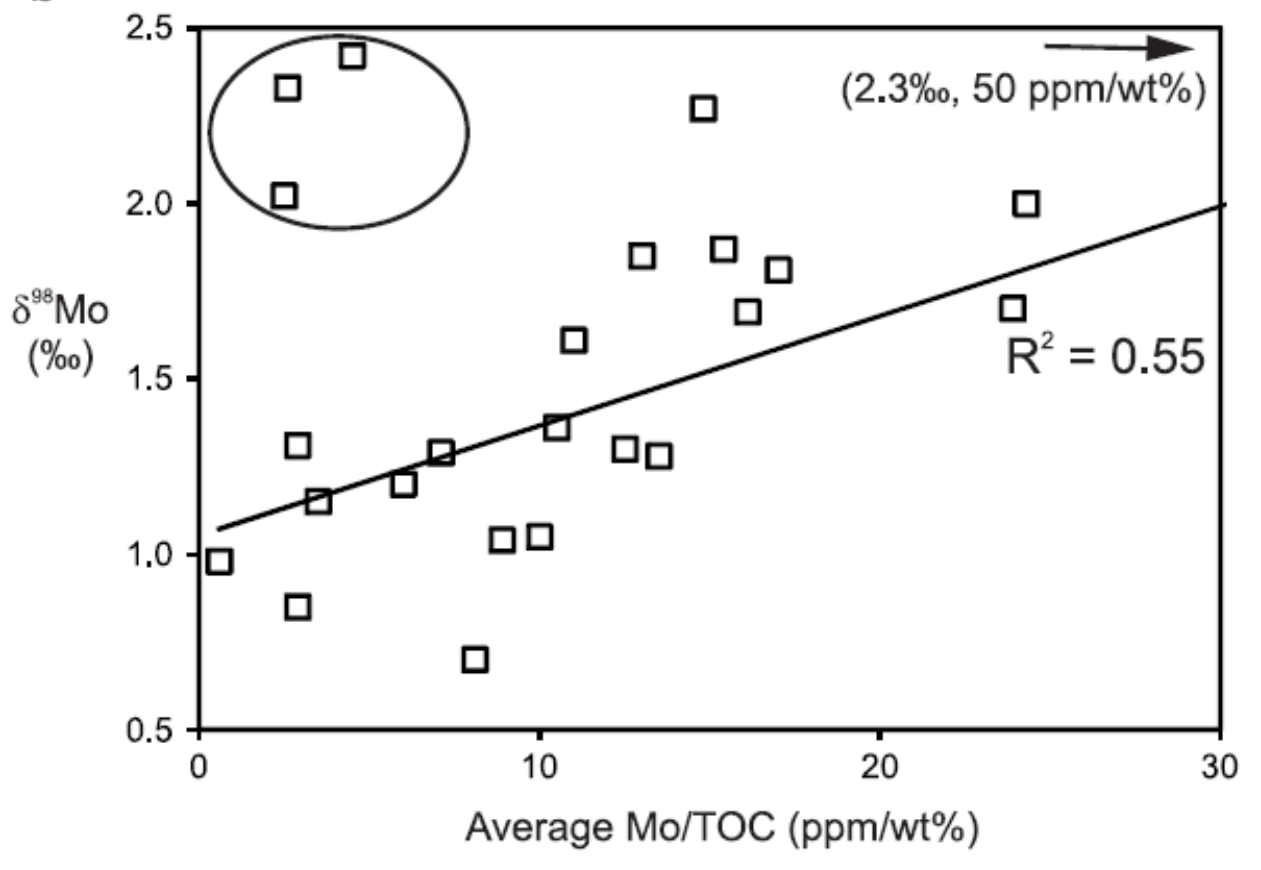




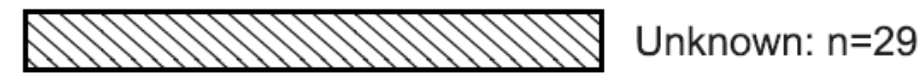

Polymetallic epithermal veins: mean $=0.9 \%, n=2$

IOGC: mean $=1.1 \%, \mathrm{n}=6$

Alpine-type fissure veins: mean $=0.5 \%, n=15$

Skarns: mean $=0.4 \%, \mathrm{n}=42$

Porphyry: mean $=0.1 \%, \mathrm{n}=180$

Greisen: mean $=1.3 \%, \mathrm{n}=3$

Perigranitic veins: mean $=0.9 \%, \mathrm{n}=9$

Pegmatites: mean $=0.5 \%, \mathrm{n}=80$

Granites: mean $=0.1 \%, \mathrm{n}=25$

2694

2695

2696

2697

2698

2699

2700

2701

2702

2703

2704

2705

2706

2707

\begin{tabular}{ccccccc}
\hline-2.0 & -1.0 & 0.0 & 1.0 & 2.0 & 3.0 \\
& & & $\delta^{98} \mathrm{Mo}(\%)$ & &
\end{tabular}




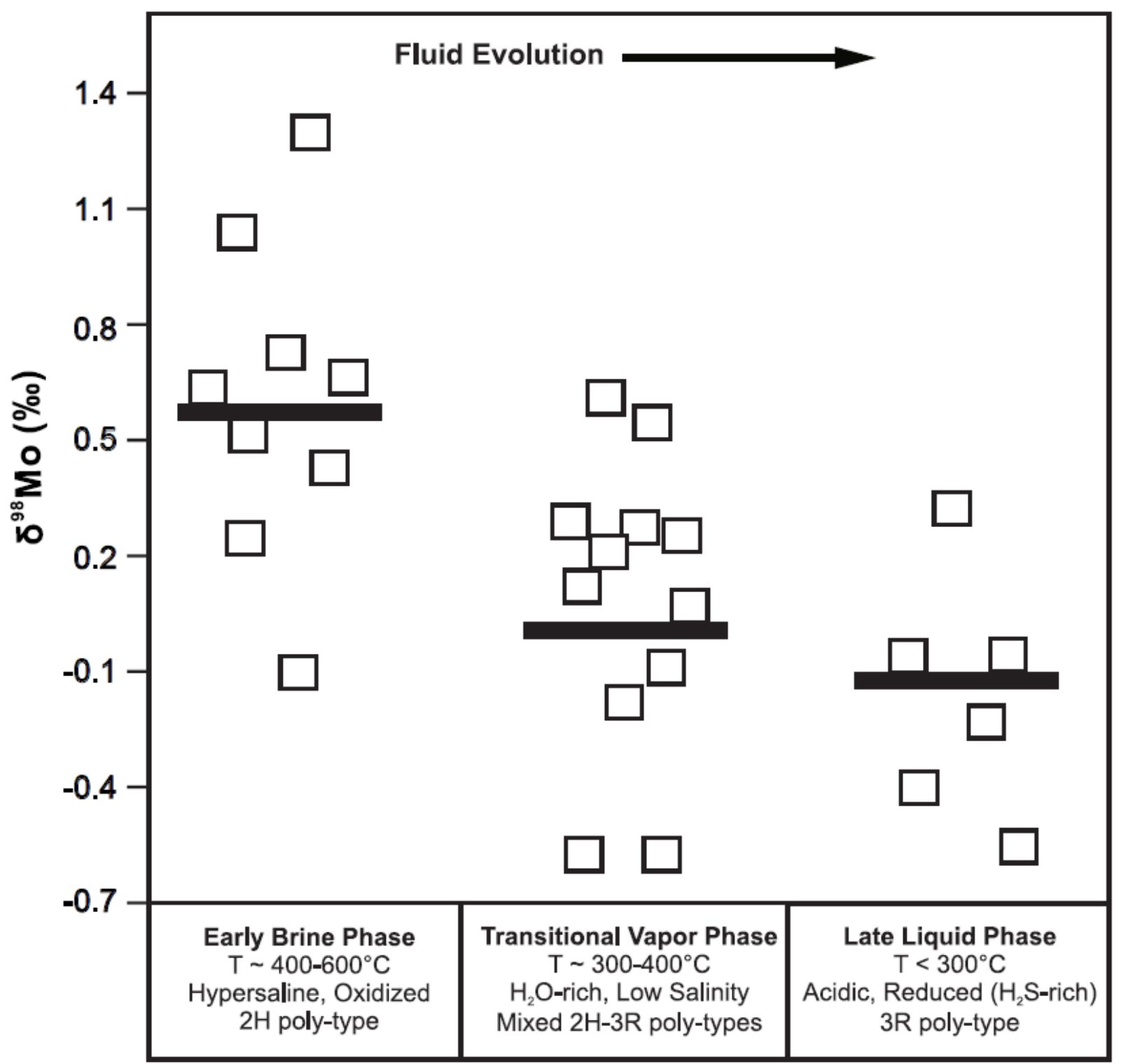

Mineralizing Stages 
$2720 \quad$ Figure 15

2721

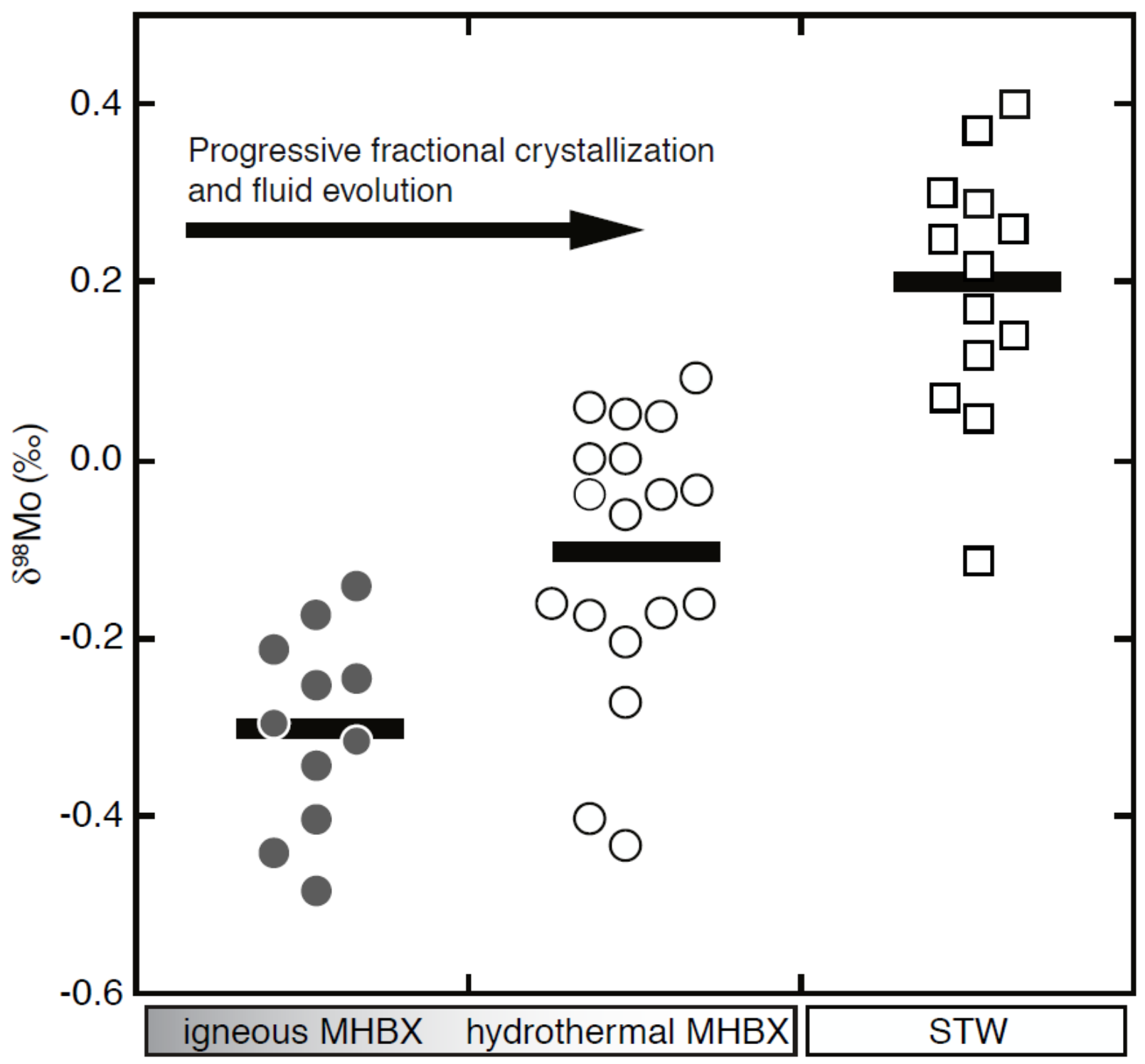

